\title{
The farming and husbandry of Colossoma macropomum: From Amazonian waters to sustainable production
}

\author{
Alexandre Wagner Silva Hilsdorf $^{1}{ }^{\oplus}$ | Eric Hallerman $^{2}{ }^{\circledR}$ |

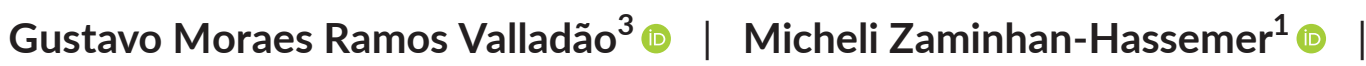

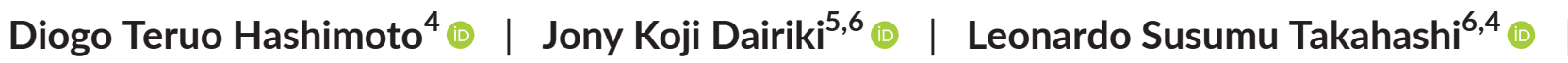 \\ Francielly Corrêa Albergaria ${ }^{7}$ (1) | Maria Emília de Sousa Gomes ${ }^{7}$ (i) |

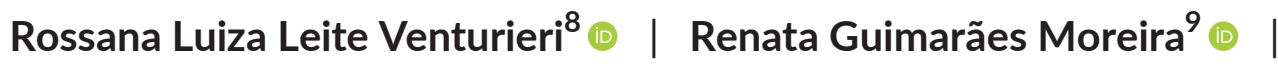 \\ José Eurico Possebon Cyrino ${ }^{10}$ \\ ${ }^{1}$ Núcleo Integrado de Biotecnologia, Universidade de Mogi das Cruzes, Mogi das Cruzes, SP, Brazil
2Department of Fish and Wildlife Conservation, Virginia Polytechnic Institute and State University Blacksburg, Virginia, USA
${ }^{3}$ Laboratório de Parasitologia e Patologia de Organismos Aquáticos, Universidade Nilton Lins, Manaus, AM, Brazil
${ }^{4}$ Centro de Aquicultura da, Universidade do Estado de São Paulo, Jaboticabal, SP, Brazil
${ }^{5}$ EMBRAPA Amazônia Ocidental, Manaus, AM, Brazil
${ }^{6}$ Departamento de Produção Animal, Faculdade de Ciências Agrárias e Tecnológicas, Universidade Estadual Paulista, Dracena, SP, Brazil
${ }^{7}$ Departamento de Ciência dos Alimentos, Universidade Federal de Lavras, Lavras, MG, Brazil
${ }^{8}$ Original Amazon Assessoria Empresarial Ltda., São Paulo, SP, Brazil
${ }_{9}^{9}$ Departamento de Fisiologia, Instituto de Biociências, Universidade de São Paulo, São Paulo, SP, Brazil
${ }^{10}$ Departamento de Zootecnia, Escola Superior de Agricultura Luiz de Queiroz, Universidade de São Paulo, Piracicaba, SP, Brazil
}

Correspondence

Alexandre Wagner Silva Hilsdorf, Núcleo Integrado de Biotecnologia, Universidade de Mogi das Cruzes, Mogi das Cruzes, SP,

Brazil.

Email:wagner@umc.br

José Eurico Possebon Cyrino,

Departamento de Zootecnia, Escola

Superior de Agricultura Luiz de Queiroz,

Universidade de São Paulo, Piracicaba,

SP, Brazil.

Email: jepcyrino@usp.br

Funding information

The authors wish to acknowledge all the financial supporters of our research, as follows: Coordenação de Aperfeiçoamento de Pessoal de Nível Superior-Brasil (CAPES), Conselho Nacional de Desenvolvimento Científico e Tecnológico (CNPq), Fundação de Amparo à Pesquisa do Estado de São Paulo (FAPESP), Fundação de Amparo à Pesquisa do Estado de Minas Gerais (FAPEMIG), Fundação de Amparo à Pesquisa do Estado do Amazonas (FAPEAM) and U.S. Department of Agriculture under the National Institute for Food and

\section{Abstract}

Within the rich diversity of South American freshwater fish, Colossoma macropomum (Characiformes: Serrasalmidae), known as tambaqui, cachama or blackfin pacu, can reach $30 \mathrm{~kg}$, is a traditional product in regional fish markets and has drawn the attention of fish farmers since the 1930s. Considerable progress achieved in different fields of aquaculture science has contributed to the growth of tambaqui production. Tambaqui has proven suitable for both monoculture and polyculture systems, and for both extensive and intensive production systems aimed at achieving sustainable, higher productivity with minimal environmental impact. Studies of the reproductive anatomy and physiology of the species proved fundamental to development of techniques to boost commercial production, contributing to development of protocols for hormonally induced spawning and artificial propagation in the 1970s. Newly hatched larvae must be fed with live foods until they can be weaned to artificial feeds at about $100 \mathrm{mg}$ weight. Despite its importance for aquaculture, only a few studies have reported components of quantitative genetic variance and parameters for weight at age, morphometric traits and disease resistance. Genomic tools currently available can be applied to detect variation relevant to performance and to accelerate the process of genetic improvement. While the species' feeding habit allows the use of diets 
Agriculture. AWSH (304662/2017-8), DTH (311559/2018-2), LST (312051/2018-2) and RGM (305493/2019-1) are recipients of CNPq productivity scholarships containing 75\%-85\% plant protein, much more work needs to be done to optimize aquafeeds. Refinement of tambaqui production methods has the potential to significantly boost South American aquaculture. We recommend research on diets, genetic improvement and system optimization to spur further productivity and achieve sustainable tambaqui culture.

\section{KEYWORDS}

aquaculture, cachama, Characiformes, cultivation, gamitana, tambaqui

\section{1 | HISTORICAL CONTEXT}

Colossoma macropomum (Cuvier 1818) (Order Characiformes, Family Characidae) is the largest characin species in the Amazon and Orinoco river basins of South America. It is native to many South American countries, with distinct, regional common names, such as 'cachama' or 'morocoto' in Venezuela, 'cachama negra' or 'gamitana' in Colombia, 'paco' in Ecuador, 'gamitana' in Peru, 'pacu' in Bolivia, and 'tambaqui', 'bocó' or 'ruelo' (young forms) in Brazil. Termed 'black-finned pacu' in English, C. macropomum has been introduced into the United States, Mexico, China, Thailand and the Philippines for aquaculture purposes; feral populations have not become well established in these countries. ${ }^{1-8}$

C. macropomum, hereafter termed 'tambaqui', is a Neotropical (preferred temperature range, $25-34^{\circ} \mathrm{C}$ ), potamodromous, benthopelagic, frugivorous-omnivorous fish often exceeding $1.0 \mathrm{~m}$ in total length and $30 \mathrm{~kg}$ (Figure 1). Ecologically, C. macropomum plays an important role in seed dispersal throughout the flooded forests of the Amazon basin. The reproductive behaviour of tambaqui is typical of most migratory characins. The adults feed in flooded, blackwater forests or floodplain lakes during the high-water season. With receding water levels, ripe 3- to 4-year-old fish migrate in large schools to spawn in whitewaters. The larvae, postlarvae and juveniles drift to nutrient-rich floodplain lakes until recruiting to the reproductive stage during the next spawning season., 1,3,-11

Tambaqui is a regionally important fishery resource, with commercial landings ranking among the top ten in the Amazon

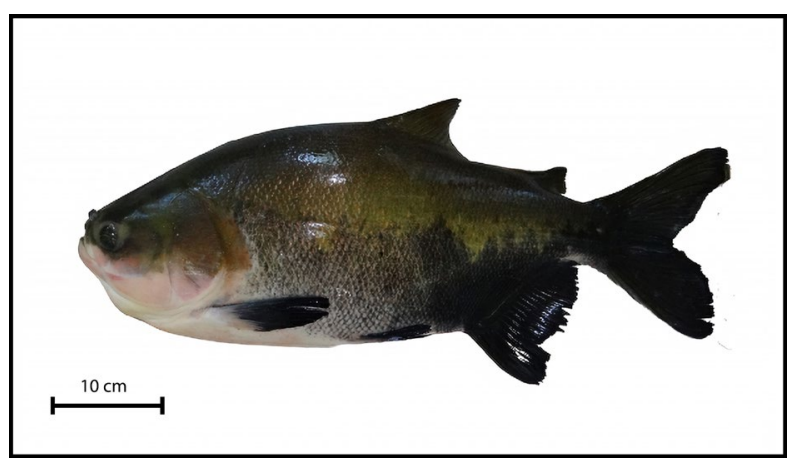

FIGURE 1 Colossoma macropomum-tambaqui (Source: Photo by Alexandre W.S. Hilsdorf) region's fish markets. Long a main species for local consumption and commercialization, extensive catches have been reported since the 19 th century. ${ }^{12,13}$ The flesh quality and high price of its products drew the attention of research groups in the early 1900s. The first records of domestication and farming of tambaqui date back to the 1930 s, when R. von Ihering ${ }^{14}$ advocated the husbandry of the species for aquaculture purposes. ${ }^{15}$ In the early 1960s, research institutions in Brazil and neighbouring Amazon basin countries acknowledged tambaqui as a viable candidate for commercial fish farming. ${ }^{16-18}$ In the early 1980s, the 'Red Regional de Entidades y Centros de Acuicultura de America Latina' (ie the Latin American Aquaculture Institutions and Research Centers Network) was established and sponsored technical workshops and symposia on tambaqui production. The very first meeting of the 'Grupo de Trabajo Tecnico-Cultivo de Colossoma' (Technical Working Group-Farming of Colossoma) was held at the then 'Centro de Pesquisa e Treinamento em Aquicultura' (Aquaculture Training and Research Center-CEPTA), Pirassununga in Sao Paulo state, Brazil, in 1988. The workshop was attended by delegates from Brazil, Colombia, Ecuador, Panama and Venezuela, and by Dr. Ulrich Saint-Paul, from Germany, an international expert in the farming and husbandry of Colossoma. ${ }^{19,20}$ The proceedings of the workshop were likely the first compilation dedicated to farming of Colossoma. $^{21}$

The development of artificial propagation and hatchery techniques, and the consequent availability of tambaqui fingerlings on a regular, commercial basis during the 1980 s consolidated tambaqui as a major aquaculture species. The species' (i) suitable response to induced spawning under hatchery conditions; (ii) adaptation to routine farming management; (iii) resilience under high stocking densities under grow-out conditions; (iv) unsurpassed growth rate (2-3 kg year $\left.{ }^{-1}\right)$ in most warmwater $\left(27\right.$ and $\left.30^{\circ} \mathrm{C}\right)$ farming conditions; (v) resistance to low oxygen levels and poor water quality; (v) omnivorous feeding habit and readily acceptance of formulated aquafeeds; (vi) disease resistance; (vii) high market value and consumer acceptance; (viii) high added value for fishery products (ribs, loin and whole fish), and other biological and zootechnical characteristics soon boosted the popularity of tambaqui among fish farmers, turning the species into the most successful case of farming and husbandry of Neotropical characins. ${ }^{19,22}$

Data on fishery landings and aquaculture production of Colossoma macropomum lack precision, even those reported in 
the FAO Fisheries and Aquaculture Global Production Statistics Database. The explanation is that the common name of $C$. macropomum in most Amazonian countries is 'cachama', but that common name may include other Amazonian characins, such as Piaractus brachypomus. In any case, Brazil is the most typical country regarding the farming of tambaqui. Statistics on landings and farm production of tambaqui in Brazil registered just 8.0 tonnes in 1994 and peaked at 139,000 tonnes in 2014 . The total of fishery and aquaculture yield of native species decreased circa $4.5 \%$ since then, due to the rise of tilapia production; however, tambaqui and its hybrids still lead the farming and husbandry of native species, contributing 102,600 tonnes, a sizeable $19.7 \%$ of the total landings of freshwater farmed fish in the most recent reports (Figures 2 and 3). ${ }^{23,24}$

A multi-database search of Google Scholar, PubMed, Aquatic Science and Fisheries Abstracts (ASFA), and Biological Abstracts back to the 1960s recovered 914 references under the keyword 'Colossoma macropomum', with reports heavily concentrated within the last two decades (Figure S1). Major research areas and themes on the farming and husbandry of tambaqui encompass the following: (i) physiology (22\%), (ii) feeding and nutrition (21\%), (iii) production and management (21\%), (iv) diseases and health (9\%), (v) reproduction and larviculture (8\%), (vi) genetics and breeding (7\%), (vii) ecology (6\%), (ix) fish processing (4\%), and ( $x$ ) sociology and applied economics (2\%). Reviews of tambaqui biology and farming have been published elsewhere. ${ }^{3,9,19,20,22,25-28}$ Against this background, we update the state of knowledge of tambaqui aquaculture by assembling contributions from experts in areas extending from genetics to fish processing, so that the trajectory of $C$. macropomum farming and husbandry can be documented to foster the development of the species as a within the context of world aquaculture.

\section{I FARMING AND PRODUCTION SYSTEMS}

Description and characterization of tambaqui production systems date to the late 1970s and early 1980s (Supporting Information/ Infographic 1). Lovshin, ${ }^{29}$ Lovshin et al. ${ }^{30,31}$ Honda et al. ${ }^{32}$ Werder \& Saint-Paul, ${ }^{33,34}$ Goulding \& Carvalho, ${ }^{3}$ and Saint-Paul ${ }^{19,20}$ reported findings on the species' biological characters and farming potentialgrowth rate, feeding habit, and reproductive behaviour-and the near-total dependence on fisheries to meet $>95 \%$ of market demand in Manaus, Brazil. Neighbouring states supplied the remaining $5 \%$ of tambaqui products commercialized in the region. Economic development and population growth in the region led to increased market demand, with consequent overfishing that encouraged commercial farming of tambaqui. Increased demand for tambaqui also forced a shift in consumer purchasing habits, triggering the acceptance of socalled 'roelos', that is, juvenile tambaqui averaging 2 3 kg live weight produced in farming operations, as compared to full-grown, wildcaught fish, averaging in excess of $10 \mathrm{~kg}$ live weight usually available at northern Brazilian fish markets. ${ }^{35-39}$ As a result, the supply of tambaqui products to Manaus, the largest regional marketing centre, shifted from the local fishery to farming operations in the neighbouring Brazilian states of Rondônia (RO), Acre (AC) and Roraima (RR).

Early trials on the farming and husbandry of tambaqui characterized the species as easily adaptable to farming conditions and to feeding on formulated aquafeeds. ${ }^{19,20,34,40,41}$ Tambaqui proved a rather versatile fish and is now farmed in extensive, semi-intensive and intensive systems within Brazil, neighbouring South American countries such as Colombia, Peru and Venezuela, ${ }^{35,42}$ Central America's Panama and Honduras ${ }^{43,44}$ and even countries in Asia. ${ }^{45}$ An increasing number of publications show growing interest in the

Brazilian continental fish farming production and Colossoma macropomum production

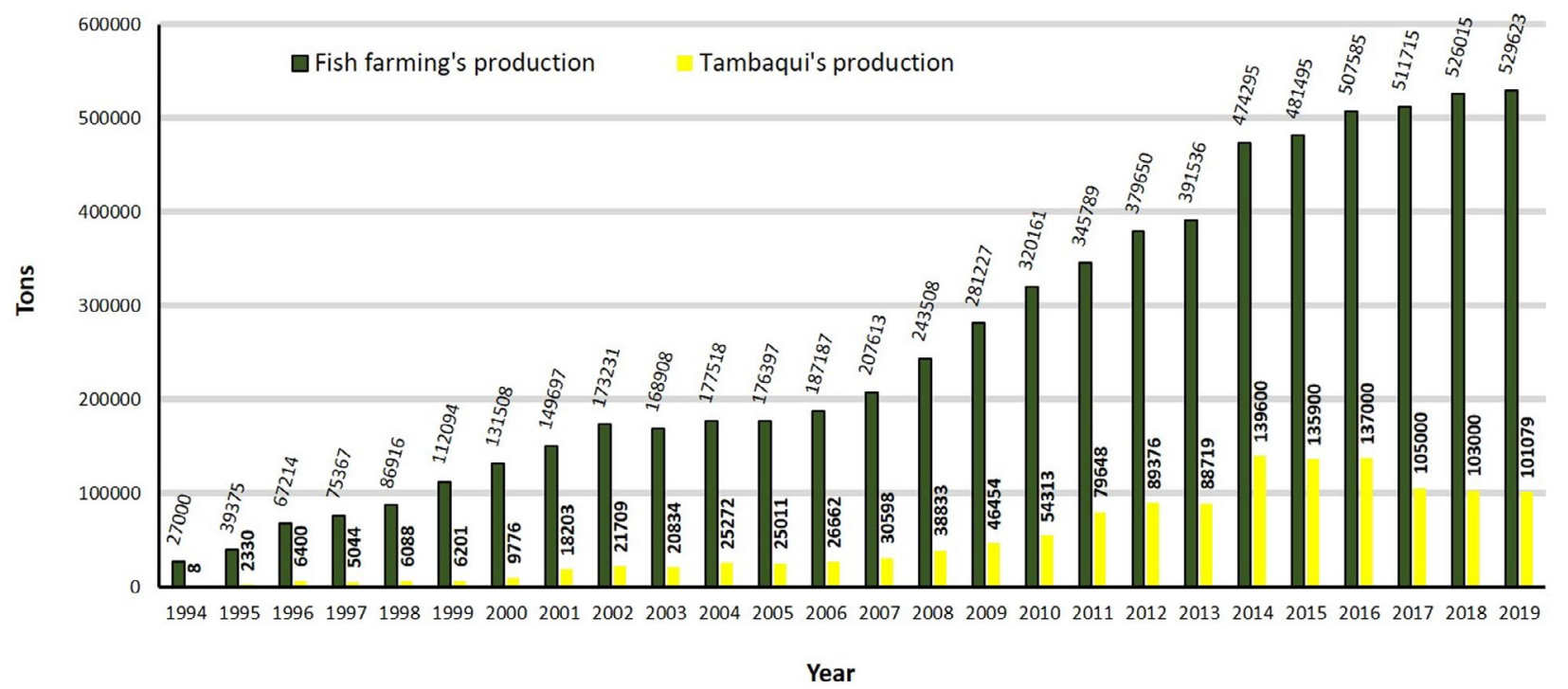

FIGURE 2 Continental fish farming production and Colossoma macropomum production in Brazil, 1994-2019. Statistical data adapted from IBGE (2020) and FAO-FIGIS (2020) 
Percentage of Colossoma macropomum production in Brazilian continental fish farming

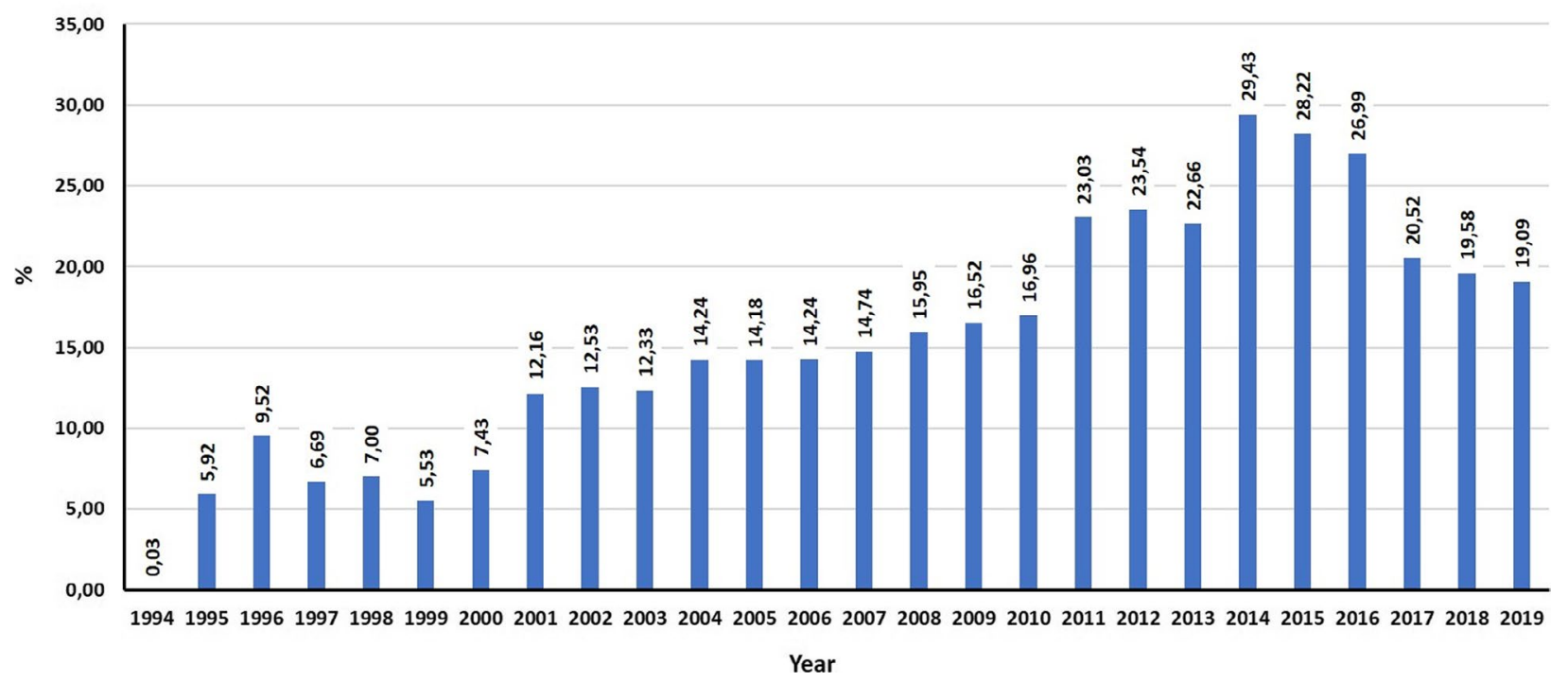

FIGURE 3 Per cent contribution of Colossoma macropomum to the landings of farmed freshwater fish in Brazil, 1994-2019. Statistical data adapted from IBGE (2020) and FAO-FIGIS (2020)

adaptation and development of the production systems in other regions (Figures S2 and S3).

From the very first attempts, tambaqui has proven suitable for both monoculture or polyculture systems, with attendant advantages and disadvantages. Peralta and Teichert-Coddington (1989) ${ }^{43}$ for instance, reported that in comparison with Nile tilapia Oreochromis niloticus, tambaqui presents greater growth performance when raised in ponds. Teichert-Coddington ${ }^{44}$ reported that polyculture with $75 \%$ tilapia and $25 \%$ tambaqui leads to increased overall fish productivity. Tambaqui also can be farmed successfully in polyculture with grass carp Ctenopharyngodon idella, catfish curimbatá Prochilodus marggravii, common carp Cyprinus carpio, the characid pirapitinga Colossoma brachypomus, and the cichlid silver (peacock) sunfish Chaetobranchus semifasciatus. ${ }^{46-48}$ For some time, subsistence pig cum fish or integrated poultry fish farming of tambaqui, erroneously labelled extensive production systems because no formulated aquafeed was used, was encouraged or even enforced in some areas of the Brazilian Amazon. ${ }^{49}$ However, as might be expected, several negative aspects of those integrated systems, such as deterioration of water quality and associated environmental and sanitary concerns, reduced yield and decreased the quality of the fishery products. While optimized management of production systems and nutrient balances might have addressed these issues, producers and would-be producers abandoned the integrated aquaculture approach. ${ }^{50}$ Currently, polyculture of tambaqui and other benthopelagic species, such as freshwater prawn Macrobrachium jelskii and freshwater shrimp Macrobrachium amazonicum, is a developing trend. ${ }^{51-56}$

Farming tambaqui in ponds in a semi-intensive system depends upon utilization of the system's natural productivity-phytoplankton and zooplankton-as a primary food source, especially for fingerling and juvenile fish, followed by the use of supplementary aquafeeds in the grow-out phase. This farming system enables harvest of up to 10 tonnes of fish ha ${ }^{-1}$ year $^{-1}$; therefore, the economic feasibility of such systems is quite attractive. ${ }^{36,37,57-63}$ The adoption of intensification practices, such as continuous or supplementary aeration, water renewal, use of complete, extruded, age(phase)-specific aquafeeds and correct feed management, although labour-intensive and prone to higher production costs, increases productivity and economic viability. However, intensification of the farming system brings higher economic risk to the activity and, unless the system is implemented and administered as an agribusiness, the investment might not prove profitable. $^{62,64,65}$

The farming of fish in cages or other net enclosures in an intensive system allows use of almost any kind of water body for fish farming purposes, particularly large reservoirs, enabling the harvest of large quantities of quality fish. ${ }^{66,67}$ Tambaqui has proven fit for cage farming. Defining the best stocking densities, volumes of net enclosures and cages, carrying capacities and best management practices for cage farming of tambaqui spurred multiple research efforts with good results. ${ }^{35,38,50,68-71}$ However, the performance of tambaqui in raceways proved not comparable to those of semiintensive and intensive pond or cage systems. A possible explanation is that tambaqui is native to lentic ecosystems and does not adapt well to raceways. Seemingly, growth rate and productivity of tambaqui are not negatively affected by slow water flow when farmed in irrigation channels, and the same is true for tambaqui hybrids farmed in recirculating aquaculture systems under moderate water flow rates. ${ }^{36,72-76}$ For example, Silva et al. ${ }^{77}$ reported that juvenile tambaqui $(0.35 \pm 0.10 \mathrm{~g})$ performed rather well in a recirculating aquaculture system (RAS) with small, 28-L aquaria; thus, this study cannot be directly extrapolated to larger, commercial RAS. The production and yield of tambaqui in different farming systems are presented in Table 1. 


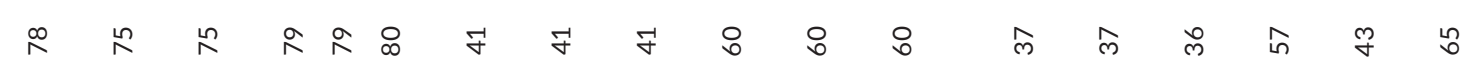

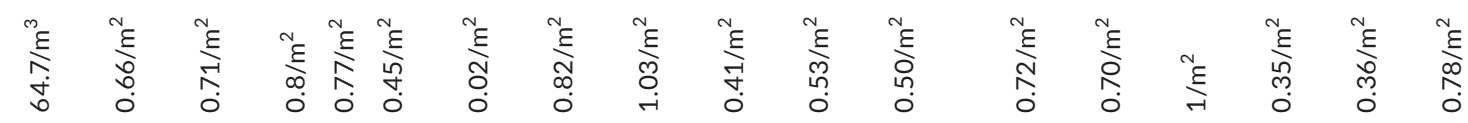

$\frac{\circ}{\mathrm{u}}$

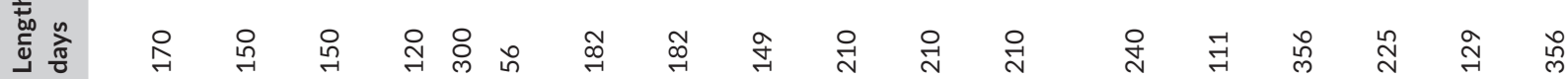

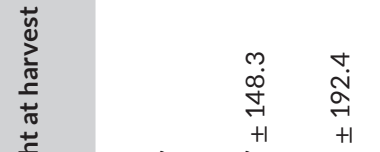

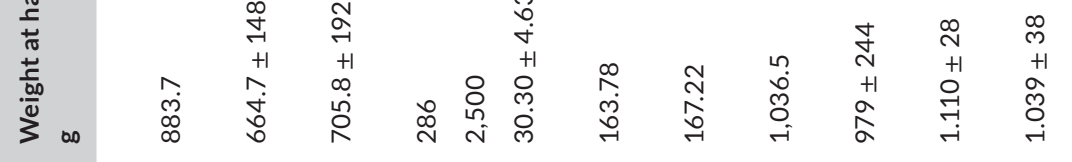

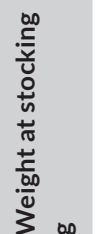

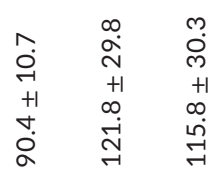

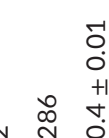

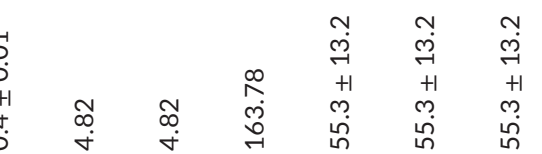

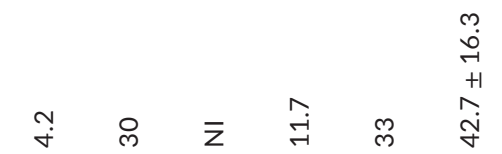

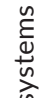

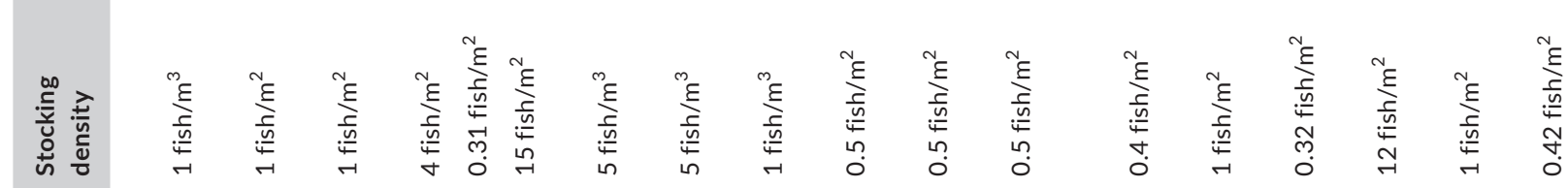
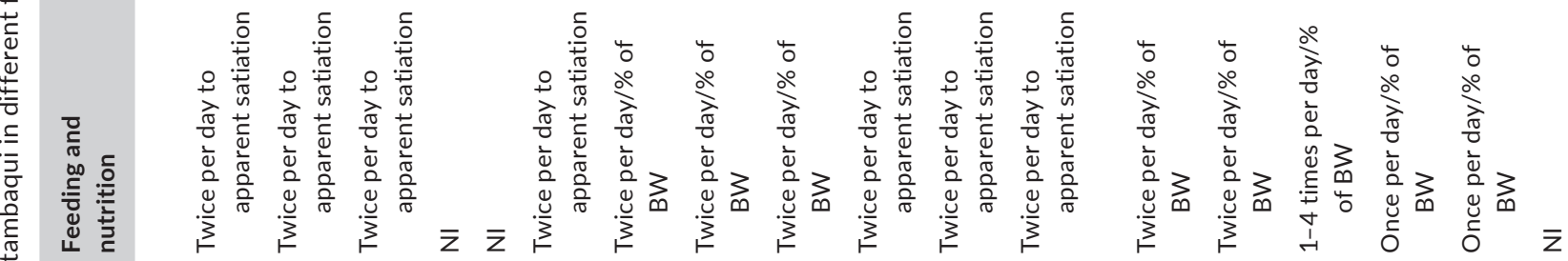

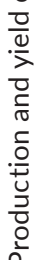
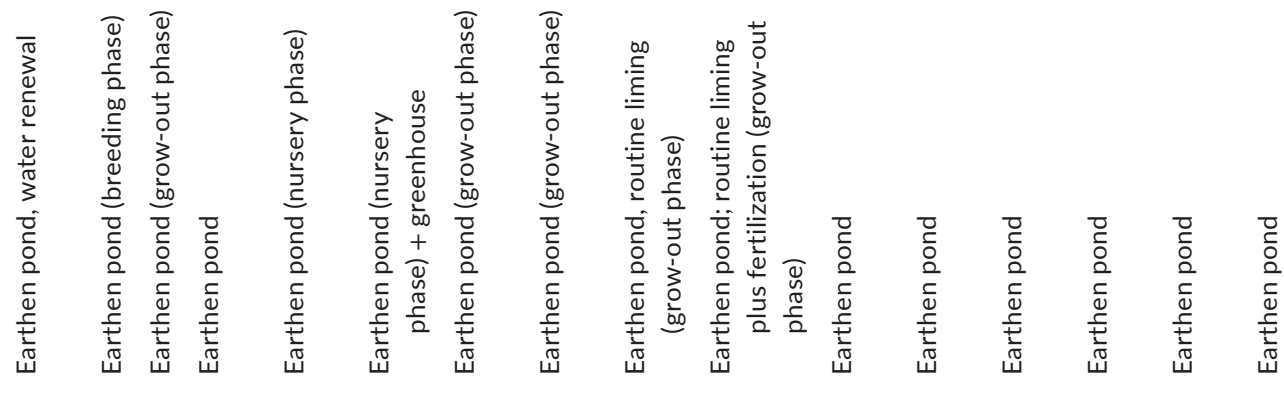


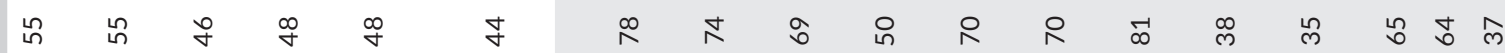

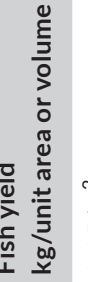

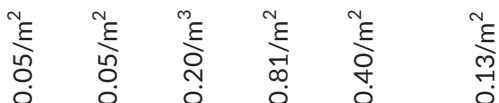

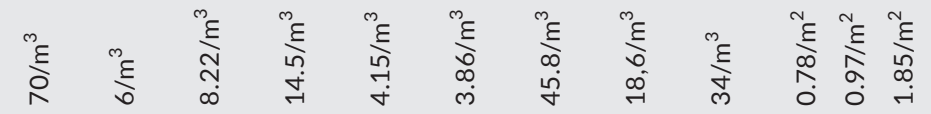

$\frac{0}{\mathrm{~S}}$

苟

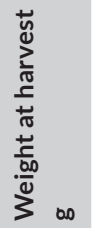

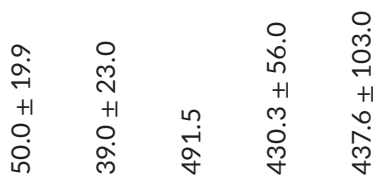

aे

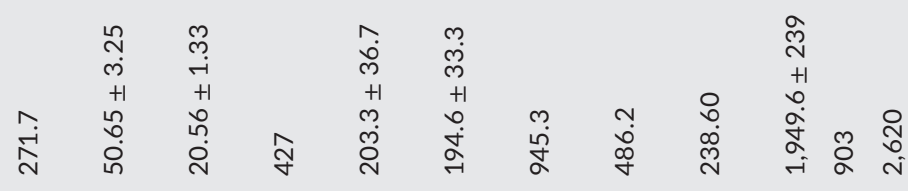

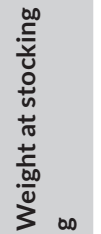

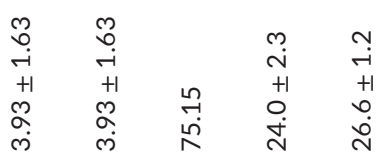

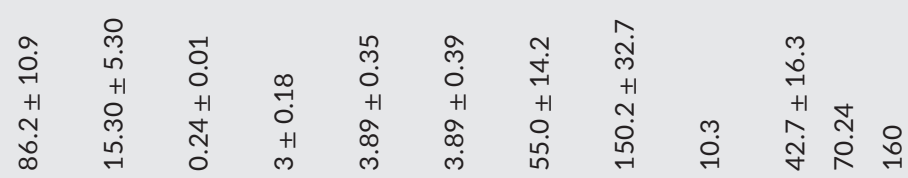

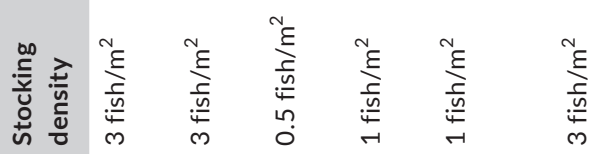

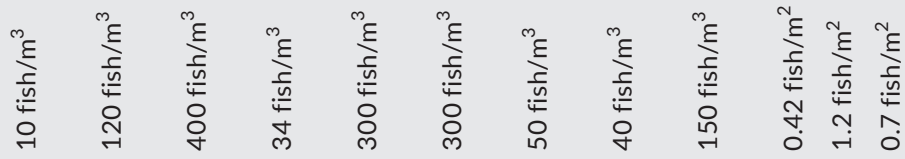

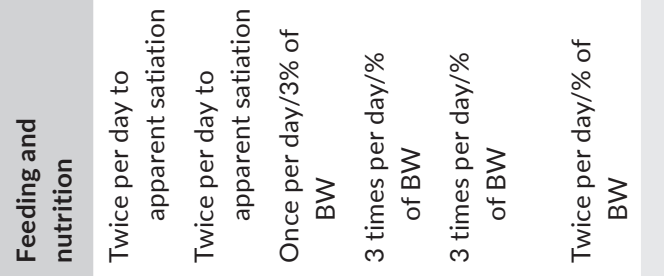

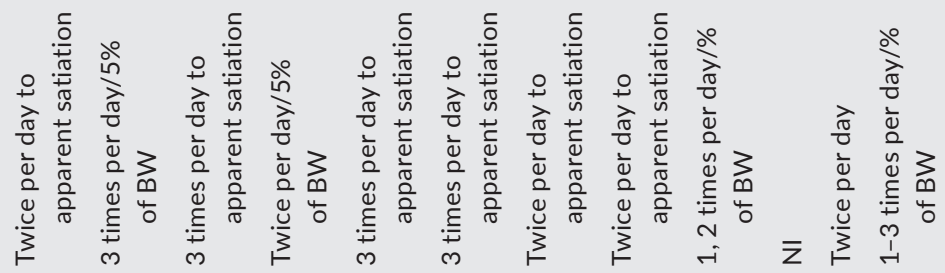

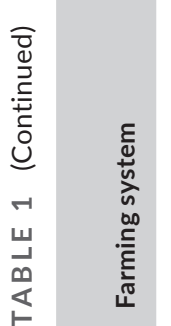

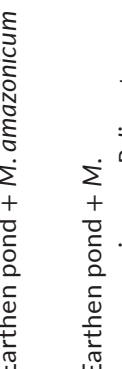
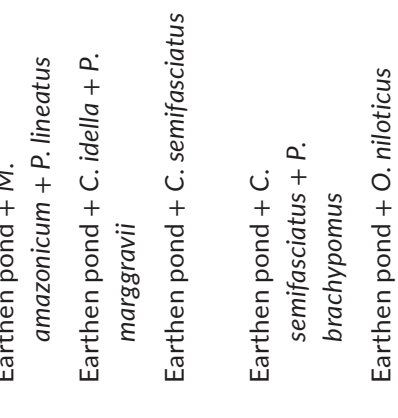

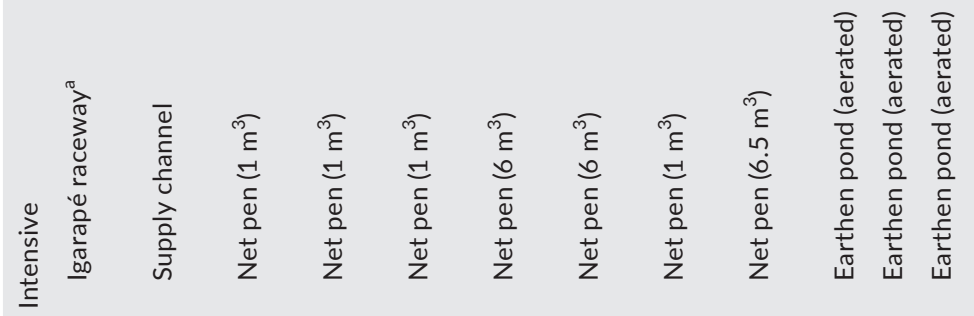




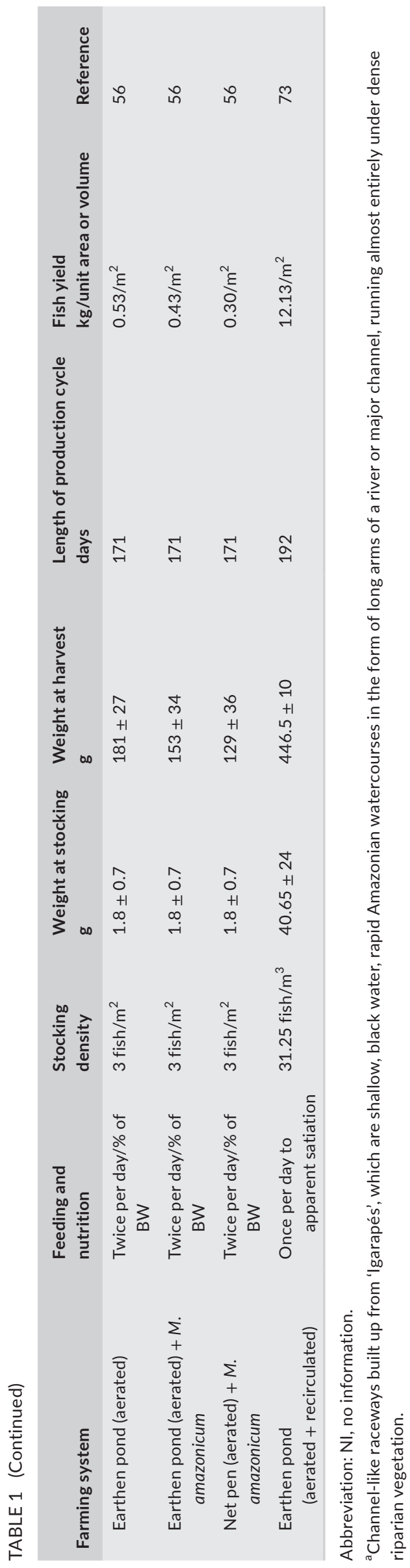

Current tambaqui farming practices aim at higher productivity with minimal environmental impact, relying on mathematical models to support decision-making in farm management. ${ }^{74,82,83}$ Intensive pond production of tambaqui is the most profitable system, but because it depends on intrinsic regional conditions-including weather, prices of agricultural inputs and market conditions, including the currency exchange rate-it may experience peaks and troughs in yield and profitability. ${ }^{79,80,84}$ Pedroza Filho et al. ${ }^{85}$ reported that cage farming of tambaqui is on the rise in the northern Brazilian states of Tocantins (TO), Pará (PA) and Mato Grosso (MT), where large, multiple-use, nearly pristine reservoirs, which may yield quality fish (notably devoid of off-flavour), are readily available for fish culture operations. However, logistic hurdles are yet to be overcome to advance the cage farming system to the state of pond farming, especially regarding economic feasibility.

Steady growth of productivity stirred interest in tambaqui production, encouraging research on transport of juvenile fish, physiology of cultured fish and health management, especially research on emerging, stress-related parasitic and bacterial diseases affecting intensively farmed stocks. ${ }^{86}$ Widespread parasitic diseases are regarded as the leading cause of decreasing production and harvest, mainly in the northern region, causing stagnation of the species' national production (see the Diseases section below). ${ }^{87-104}$

Characterizing the production system of tambaqui requires considering aspects inherent to regional climatic differences and the high degree of adaptability of tambaqui, which, with the exception of southern-most regions of South America, can be produced at commercial scale with technical-economic feasibility. Such aspects led tambaqui to place second in the ranking of national production and first position among native fish, contributing significantly to the development of Brazilian aquaculture. Notwithstanding, the goal of intensifying farming systems while achieving sustainability guides research on tambaqui production. This will depend upon effective aquaculture extension to support improvement of farm management practices, changing the traditional mindset of many growers, as well as further application of aquaculture economics and sustainability assessments. The ultimate aim is to maintain supply to the domestic market with subsequent opening of external markets, touting the valuable quality and organoleptic characteristics products of the species.

\section{3 | REPRODUCTION AND HATCHERY}

Tambaqui is a migratory characin (Supporting Information/ Infographic 2). In nature, female tambaqui are sexually mature at 4 to 5 years of age at $58 \mathrm{~cm}$ total length. ${ }^{1}$ During the reproductive period, adults leave floodplains, streams, and lakes, assembling in large schools that head towards spawning areas in the main river channels. Spawning season peaks at the beginning of the flood period in the so-called 'white, nutrient-rich water rivers'. ${ }^{105-107}$ Tambaqui has a synchronic ovarian development, is a group-spawning species and does not provide parental care. The larvae are carried by the current 
for four to 15 days, covering $400 \mathrm{~m}$ to $1,300 \mathrm{~km}$, drifting to floodplain lakes where the young spend the juvenile phase. ${ }^{107,108}$

Induced spawning and artificial propagation of tambaqui date back to the 1970s, with the first studies by researchers from the Departamento Nacional de Obras Contra a Seca (National Bureau of Actions Against Drought-DNOCS). ${ }^{109}$ Since then, several manuals and field guides have been published, on topics ranging from broodstock formation and maintenance to commercial breeding. ${ }^{22,27,110-113}$ Confined males reach puberty before females and may present testicular development at 5 months of age, while females begin oogenesis at 7 months; males and females reach sexual maturity in 3 and 4 years, respectively, at a total weight of 3-6 kg. ${ }^{114,115}$ Campos Baca ${ }^{63}$ reports that some government aquaculture hatcheries in Brazil may use broodfish for 12 years, while in Iquitos, Peru, for instance, broodfish are used for a maximum of 4 years. The difference in practice may reflect geographic differences; in Peru, which is mostly in the Amazon basin, one can easily capture broodstock, while many aquaculture regions of Brazil are far from the Rio Negro system where broodfish are most often captured. In any case, broodfish present better spawning performance at ages 4-7 years, at a body mass of $3-7 \mathrm{~kg}$.

\section{1 | Broodstock maintenance}

Consensus is yet to be established regarding hatchery operations and management and biological parameters relevant to reproduction of tambaqui in confinement. As a rule, broodfish are usually selected from production ponds and grown to maturity in dedicated tanks or ponds under natural conditions, a procedure not well advised from a genetic management standpoint. In the event of recurrent propagation of a limited number of females and males followed by grow-out and reproduction of their progeny, the chance for inbreeding increases markedly (see the Genetics, Genomics and Breeding section).

Tambaqui is reared in warm waters in which low dissolved oxygen content is common, so monitoring stocking density of broodstock is key to successful hatchery operations. However, there is once again no consensus on ideal stocking density for broodstock maintenance and development, and most farms operate using specific, locally defined procedures. Most aquaculture centres in Peru work using a stocking density of 200-400 g broodfish $\mathrm{m}^{-2}$ in monoculture systems. However, on some farms, this load is reduced to $90 \mathrm{~g} \mathrm{~m}^{-2}$ (Iquitos, Peru), $66 \mathrm{~g} \mathrm{~m}^{-2}$ (southeast Brazil) or $50 \mathrm{~g} \mathrm{~m}^{-2}$ (northeast Brazil), but exceptionally in Venezuela, stocking density of tambaqui broodfish can be as high as $700 \mathrm{~g} \mathrm{~m}^{-2}$. ${ }^{63}$ Woynarovich \& van Anrooy ${ }^{27}$ recommend stocking 10 - to $153.0-\mathrm{kg}$ broodfish into a $1000-\mathrm{m}^{2}$ pond. Streit et al. ${ }^{113}$ recommend stocking one fish of up to $3 \mathrm{~kg}$ live weight per $5 \mathrm{~m}^{2}$, reducing stocking density of larger fish to one fish per $10 \mathrm{~m}^{2}$.

Given that tambaqui is a migratory fish, reproduction under captive conditions requires artificial induction to achieve final maturation and spawning with use of hormonal administration. ${ }^{27,116,117}$
Broodstock selection methods are similar among hatcheries. The choice of females suitable for hormonal induction is based on external maturation characteristics, such as dilated and bulging belly, hyperaemic genital papilla, and ovarian biopsy; choice of males is assessed by semen fluidity, checked by light pressure on the urogenital papilla. ${ }^{113,116}$

\subsection{Induced spawning and artificial propagation}

Reproduction of fish is controlled by the hypothalamus-pituitarygonadal (HPG) hormonal axis and modulated by environmental factors such as temperature, precipitation and photoperiod. ${ }^{118,119}$ Hypothalamic neurons synthesize and release neurohormonesgonadotrophin-releasing hormone $(\mathrm{GnRH})$, gonadotrophin inhibitory hormone $(\mathrm{GnIH})$ and dopamine (inhibitory), among others. These hormones modulate the production of gonadotrophins in adenohypophyseal cells. ${ }^{120}$ The gonadotrophins, follicle-stimulating hormone (FSH) and luteinizing hormone ( $\mathrm{LH}$ ) are distributed via the bloodstream, reach the testicles and ovaries and control gonadal steroidogenesis. ${ }^{121}$

Once the HPG axis of fish was characterized, multiple protocols were tested and proven suitable for use as inducing agents promoting teleost reproduction. ${ }^{122}$ Human chorionic gonadotrophin (hCG), carp pituitary extract (CPE) and commercial GnRH preparations (Ovopel ${ }^{\circledR}$, Ovaprim ${ }^{\circledR}$ and buserelin acetate, among others) each have specific dosage and latency times. Inducing agents are diluted in a liquid vehicle (usually saline solution, $0.6 \%$ ) and injected intramuscularly at the base of the dorsal fin or, more commonly, intraperitoneally at the base of the pectoral or pelvic fin of broodfish. The most common and widely used inducing agent at tambaqui farms is CPE-carp pituitary glands commercially dehydrated, macerated and diluted in saline solution. The doses are applied according to fish body mass, usually in two doses: one preparatory and the other decisive. ${ }^{27,113,116,123}$ Chellappa et al. ${ }^{124}$ used CPE and hCG to induce spawning of tambaqui and reported positive response to both treatments. However, per cent fertilization and hatching were higher for the CPE treatment (70\% and $80 \%$, respectively) than for the hCG treatment $(50 \%$ and $60 \%$, respectively), and the authors thus concluded that CPE is more effective than hCG for inducing final maturation and ovulation in tambaqui.

CPE and Ovaprim (sGnRHa) have comparable effects on the release and concentration of semen of tambaqui. Per cent ovulation is also similar for both treatments; however, the highest fertilization rate was reported for eggs from fish treated with $\mathrm{CPE}$, an indication that Ovaprim effectively induces final maturation and spawning of tambaqui, but yields lower-quality eggs. ${ }^{125}$ Comparing CPE and Ovopel ${ }^{\circledR}(18-20 \mu \mathrm{g}$ of $\mathrm{mGnRHa}$ per pellet) protocols, Souza et al. ${ }^{126}$ reported that spawning responses of females treated with the 0.2 or 0.4 pellets of Ovope ${ }^{\circledR}$ were, respectively, $100.0 \%$ and $62.5 \%$, while treatment with CPE yielded $87.5 \%$ response, with no statistically significant difference among 
treatments. However, Ovopel ${ }^{\circledR}$ promoted faster spawning, calculated as an accumulated thermic unit (ATU - average water temperature $\times$ number of hours from induction until spawning), than CPE treatment, with similar mass of oocytes released, fertility and hatching. Ovopel ${ }^{\circledR}$ is also used to increase milt release in tambaqui cryopreservation programmes. ${ }^{127}$ Woynarovich \& Van Anrooy ${ }^{27}$ present similar, detailed protocols for Ovopel ${ }^{\circledR}$ and CPE. Table 2 lists and summarizes protocols and common inducers for final maturation and spawning of tambaqui.

Induced spawning and artificial propagation of tambaqui also can be accomplished by use of buserelin acetate, which yields spawning percentage, egg mass, ovulation and fertilization similar to those of CPE. However, ATU and the number of egg releases were higher for females treated with buserelin acetate than CPE. ${ }^{138}$ Positive results from use of buserelin acetate to induce spawning of tambaqui also were reported by Almeida et al. ${ }^{140}$ who monitored embryonic and larval development. Despite the various inducing agents available and experimentally demonstrated to induce spawning of tambaqui, CPE is still most commonly used because it is easily obtained and stored, easily handled (including calculation of dose) and proven effective. The widely used CPE protocol is based upon that previously established for carps, that is for females, $5.5 \mathrm{mg} \mathrm{kg}^{-1}$ of CPE (pituitary glands macerated and diluted in $0.7 \%-0.9 \%$ saline) and applied in two doses $\left(0.5 \mathrm{mg}\right.$ and $\left.5.0 \mathrm{mg} \mathrm{kg}^{-1}\right)$, at a 12-h interval; and for males, $2.5 \mathrm{mg} \mathrm{kg}^{-1} \mathrm{CPE}$ in a single dose. ${ }^{113}$ The CPE protocol for tambaqui also can stimulate successive spawns with viable eggs 75 days after the first induction. ${ }^{150}$

\subsection{Fertilization and incubation}

Particular induced spawning agents have specific administration intervals and ATU to effectively induce gametic maturation and spawning. The ATU varies with water temperature and estimates the moment at which the gametes will be ready for fertilization (in degree-hours, varying by inducing agent; Table 2). Ova and semen are obtained with the aid of abdominal massage (extrusion) and collected into separate containers. The concentration of tambaqui semen varies from $8.5 \times 10^{9}$ sperm cells ml ${ }^{-1}$ (Streit et al. ${ }^{113}$ ) to $19 \times 10^{9}$ sperm cells $\mathrm{ml}^{-1}$ (Leite et al. ${ }^{130}$ ), which is high compared to other freshwater teleosts. Males release reasonable semen volumes $\left(2.0 \sim 50 \mathrm{ml} \mathrm{kg}^{-1}\right)$ and can be stripped more than once, provided that stripping is done gently (Woynarovich \& Van Anrooy ${ }^{27}$; see Cryopreservation section for additional material). Female tambaqui may produce as much as $5 \sim 20 \%$ body mass in eggs, that is at least a few hundred grams, ${ }^{27}$ averaging 1,200 1,500 ova g ${ }^{-1}$ egg mass. ${ }^{113,130}$

Embryonic development begins upon fertilization by the spermatozoa; as soon as spermatozoa enters the micropyle, the fertilized egg starts the hydration process and gradual closing of the micropyle. ${ }^{153}$ The hydration period varies among teleosts, ordinarily as a function of (final) egg size. Fertilization of tambaqui gametes is usually carried out in containers (most often, plastic bowls) where oocytes and semen are mixed dry, with water added shortly afterwards. A high percentage of fertilization is achieved when $1.0 \mathrm{ml}$ of semen is added to $80 \mathrm{~g}$ of egg mass (circa 95,000 oocytes) ${ }^{113}$ Regarding the spermatozoa/oocytes ratio, a high fertilization rate is reached with around 100,000 spermatozoa per oocyte. ${ }^{130}$ Fertilized, hydrated eggs are transferred to conical, continuous flow, 60 200-L fibreglass incubation jars at a rate of $2 \pm 0.5 \mathrm{~g}(2,000 \pm 500 \mathrm{eggs})$ per litre. Tambaqui eggs have high dissolved oxygen requirements, so the stocking density of eggs should be carefully monitored. It is advisable that the volume of incubation jars does not exceed 40-200 L, with a water flow of 2 3 complete exchanges per hour. ${ }^{27}$ The flow velocity during incubation should be divided into three parts: in the first third, from 1 to $2 \mathrm{~L} / \mathrm{min}$; in the second third, from 3 to $4 \mathrm{~L} / \mathrm{min}$; and in the final third, from 5 to $6 \mathrm{~L} / \mathrm{min}^{113}$ The incubation period varies with water temperature, from $17.8 \mathrm{~h}$ (at $26^{\circ} \mathrm{C}$ ) to $12.8 \mathrm{~h}$ (at $29^{\circ} \mathrm{C}$ ), ${ }^{27}$ embryonic development takes about $14-18 \mathrm{~h}$ at a temperature of $25-29^{\circ} \mathrm{C}$, and hatching can occur around $12 \mathrm{~h}$ after incubation begins. ${ }^{154}$ The entire artificial reproduction process for tambaqui is detailed by Woynarovich \& Van Anrooy ${ }^{27}$ and Streit et al. ${ }^{113}$ Environmental, nutritional and other factors affect gamete quality. ${ }^{153}$

\section{4 | Larviculture}

Larval development of teleost fish begins upon hatching and ends with resorption of the yolk sac, opening of the mouth and onset of exogenous feeding. During this period, in addition to opening of the mouth, many events occur synchronously, including inflation of the swim bladder, eye pigmentation, fin development and flexion of the notochord. Cultured tambaqui larvae open the mouth about $36 \mathrm{~h}$ after hatch and can begin to feed on filtered zooplankton. ${ }^{154,155}$ The lighting system used during larviculture can affect tambaqui larvae's capacity to capture prey. ${ }^{156}$ There are many procedures and strategies to optimize tambaqui larval rearing, ranging from production in fertilized ponds to maintenance in laboratory tanks with recirculating water. $27,133,154,156-162$

Tambaqui larvae must be fed with live feed until they can be weaned to artificial feeds at about $100 \mathrm{mg}^{161}$ Usually, the live food consists of plankton or brine shrimp Artemia salina. Plankton can be collected from fertilized ponds and can be offered directly or selected by size. Pedreira et al. ${ }^{154}$ grew tambaqui larvae through 20 days under the following dietary treatments: plankton; plankton + ration; size-selected plankton (using 350 and $1000 \mu \mathrm{m}$ meshes); selected plankton + ration; and ration. The feed was given twice daily, ad libitum. The authors observed that treatments using live food resulted in more rapid larval growth. The addition of ration to the live food also improved growth performance, although the authors did not recommend ration as the sole food source through the first days of life. They concluded that the use of live food plus ration from the third day of exogenous feeding yielded higher survival and growth of tambaqui larvae.

Tambaqui larval development may be affected by nutrition during larviculture, although information is still limited, showing mainly that decapsulated Artemia salina cysts are more efficient than inert feeds 
TABLE 2 Induction of final maturation and spawning of Colossoma macropomum

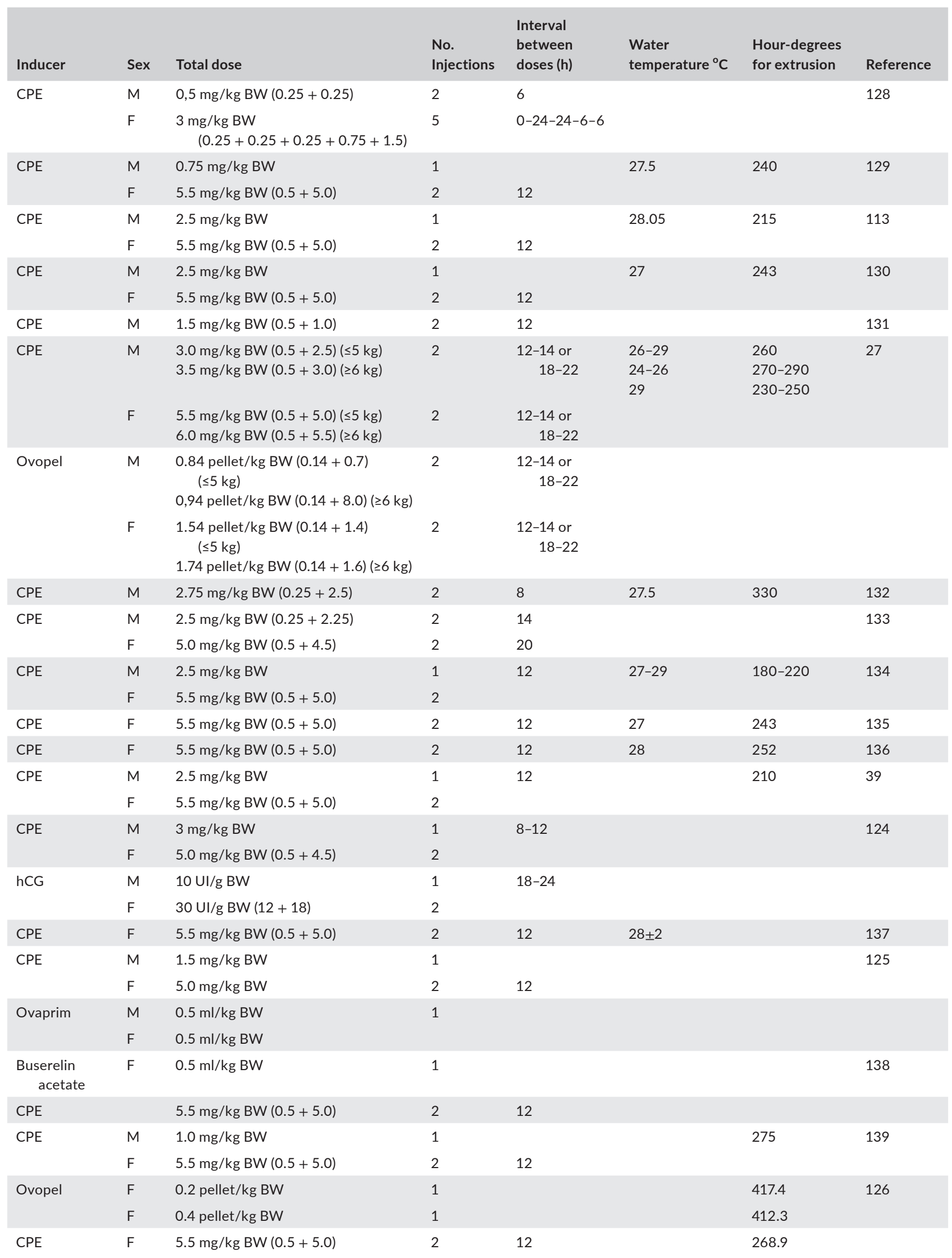


TABLE 2 (Continued)

\begin{tabular}{|c|c|c|c|c|c|c|c|}
\hline Inducer & Sex & Total dose & $\begin{array}{l}\text { No. } \\
\text { Injections }\end{array}$ & $\begin{array}{l}\text { Interval } \\
\text { between } \\
\text { doses (h) }\end{array}$ & $\begin{array}{l}\text { Water } \\
\text { temperature }{ }^{\circ} \mathrm{C}\end{array}$ & $\begin{array}{l}\text { Hour-degrees } \\
\text { for extrusion }\end{array}$ & Reference \\
\hline \multirow{2}{*}{$\begin{array}{l}\text { Buserelin } \\
\text { acetate }\end{array}$} & M & $0.08 \mu \mathrm{l} / \mathrm{kg}$ & 1 & & & & 140 \\
\hline & $\mathrm{F}$ & $0.7 \mu \mathrm{l} / \mathrm{kg}(0.20+0.50)$ & 2 & 7.5 & & & \\
\hline CPE & $M$ & $2.0 \mathrm{mg} / \mathrm{kg} \mathrm{BW}$ & 1 & . & & & 141 \\
\hline CPE & M & $1.5 \mathrm{mg} / \mathrm{kg} \mathrm{BW}$ & 1 & & & & 142 \\
\hline CPE & M & $2.75 \mathrm{mg} / \mathrm{kg} \mathrm{BW}(0.25+2.5)$ & 2 & 8 & & & 143 \\
\hline CPE & M & $2.0 \mathrm{mg} / \mathrm{kg} \mathrm{BW}$ & 1 & & & & 144 \\
\hline CPE & M & $1.0 \mathrm{mg} / \mathrm{kg} \mathrm{BW}$ & 1 & & & & 145 \\
\hline \multirow[t]{2}{*}{ CPE } & M & $2.0 \mathrm{mg} / \mathrm{kg} \mathrm{BW}$ & 1 & & & & 146 \\
\hline & $\mathrm{F}$ & $5.5 \mathrm{mg} / \mathrm{kg} \mathrm{BW}(0.5+5.0)$ & 2 & & & & \\
\hline CPE & M & $1.5 \mathrm{mg} / \mathrm{kg} \mathrm{BW}(0.5+1.0)$ & 2 & 12 & & & 147 \\
\hline Ovopel & M & $0.7 \mathrm{mg} / \mathrm{kg}$ BW & 1 & & & & 127 \\
\hline CPE & M & $2.75 \mathrm{mg} / \mathrm{kg} \mathrm{BW}(0.25+2.5)$ & 2 & 8 & & & 148 \\
\hline CPE & $M$ & $2.0 \mathrm{mg} / \mathrm{kg} \mathrm{BW}$ & 1 & & & & 149 \\
\hline CPE & $M$ & $2.5 \mathrm{mg} / \mathrm{kg} \mathrm{BW}$ & 1 & & & 240 & 150 \\
\hline \multirow[t]{2}{*}{ CPE } & $M$ & $1.5 \mathrm{mg} / \mathrm{kg} \mathrm{BW}$ & 1 & & & 240 & 151 \\
\hline & $\mathrm{F}$ & $\begin{array}{c}6.6 \mathrm{mg} / \mathrm{kg} \mathrm{BW}(0.6)+(6.0+5 \mathrm{ml} \\
\text { synthetic prostaglandin })\end{array}$ & 2 & 12 & & & \\
\hline \multirow[t]{2}{*}{ CPE } & $M$ & $2.5 \mathrm{mg} / \mathrm{kg} \mathrm{BW}$ & 1 & & & & 152 \\
\hline & $\mathrm{F}$ & $5.5 \mathrm{mg} / \mathrm{kg} \mathrm{BW}$ & 2 & & & & \\
\hline
\end{tabular}

Abbreviations: CPE, carp pituitary extract; hCG, human chorionic gonadotrophin.

for promoting larval growth. ${ }^{140}$ Due to the ease of purchase and regular supply, Artemia salina nauplii are widely used in larval fish culture, especially when producing large quantities of larvae. However, it is a high-cost input, and hence, it is important to establish the most cost-efficient feeding regime for promoting growth of tambaqui larvae. Sevilla \& Gunther ${ }^{161}$ studied the relationship between growth, feed utilization and feed ration during the first 15 feeding days for tambaqui larvae fed with Artemia nauplii. Maintenance, optimum and maximum feeding rations (1.23; 5.48 and 27.2\% body weight/ day, dry feed, respectively) and feed conversion ratios (0.4 and 0.78 optimum and maximum, respectively) were determined. They observed that at maximum feeding, the larvae grew 2.6 times faster that at optimum feeding, but the feeding costs increased 1.94 times. Depending on the cost structure at a particular hatchery, the most efficient production strategy can be designed to minimize the combined costs. ${ }^{161}$

Although Artemia salina nauplii are successfully used in tambaqui larviculture, they are saltwater crustaceans and have a limited lifetime in fresh water, which can be increased with the use of water with low salinity. ${ }^{162}$ Santos et al. ${ }^{163}$ working in recirculation systems (RAS) studied stocking densities of tambaqui larvae in slightly saline water $(2.01 \pm 0.41 \mathrm{~g}$ salt $/ \mathrm{L})$, and concluded that culture of $C$. macropomum larvae can be carried out successfully at stocking densities of up to 50 larvae/L during the first 30 days of rearing in slightly saline water in RAS.

\subsection{New technologies}

The importance of tambaqui for Brazilian aquaculture has led to numerous studies on the anatomy and physiology of the species, which proved fundamental for the development of techniques to boost commercial production. Studies of gonadal morphology, ${ }^{115,142,143,164,165}$ action of steroid hormones during the reproductive cycle in captive animals, ${ }^{115,164}$ embryonic development, ${ }^{140}$ sexual differentiation ${ }^{166}$ and molecular markers for germ cells, ${ }^{167}$ among others, made significant contributions to the development of techniques such as cryopreservation of tambaqui semen for use in induced spawning.

In the past decade, many studies have developed protocols for tambaqui semen cryopreservation, including evaluation of semen characteristics (volume, motility, sperm count), diluents, cryoprotectants, storage containers, and semen quality pre- and postfreezing, among other aspects, ${ }^{132,144-147,149,168-174}$ and a general protocol for the cryopreservation of tambaqui semen was then established. ${ }^{148}$ Cryopreservation has been used to establish germplasm banks to maintain and conserve tambaqui genetic resources. ${ }^{175}$ Reviews of cryopreservation of semen of Brazilian freshwater fish, including tambaqui, have been published by Viveiros \& Godinho ${ }^{176}$ and Garcia et al. ${ }^{177}$ Although protocols for cryopreservation of tambaqui semen are established, those for embryos and oocytes still lack good results. ${ }^{178} \mathrm{~A}$ cooling protocol for tambaqui embryos kept 
up to $8 \mathrm{~h}$ at $2^{\circ} \mathrm{C}$ has been suggested for embryos at the stages of blastospore closure ( $8 \mathrm{~h}$ post-fertilization) and appearance of the optical vesicle (13 $\mathrm{h}$ post-fertilization). ${ }^{139}$

Tambaqui farmers are interested in the possibility of producing monosex populations. Tambaqui females are on average $16 \%$ heavier than males at harvest ${ }^{115}$; hence, rearing all-female stocks can be more profitable. Effective feminization of tambaqui is achieved by feeding 30-day post-hatch larvae (14 $\mathrm{mm}$ total length) a diet supplemented with $120 \mathrm{mg}$ oestradiol $\left(E_{2}\right)$ per kg of feed for 6 weeks. ${ }^{179}$ However, an economic evaluation and consumer perception of hormone use in aquaculture operations must be considered before relying on sex-reversal techniques for improvement of routine commercial production.

Because triploid individuals are sterile and exhibit more rapid growth in many teleost species, triploidization via chromosome set manipulation has been evaluated for tambaqui. ${ }^{180}$ Triploidy induction using thermal shocks was successful, with higher hatching and triploid induction rates for heat shock $\left(41^{\circ} \mathrm{C}\right.$ for $\left.2 \mathrm{~min}\right)$ than for cold shock ( $6^{\circ} \mathrm{C}$ for $10 \mathrm{~min}$ ); however, the protocols must be improved to increase the percentage of triploidy. ${ }^{151}$

\section{6 | Perspectives on advances regarding tambaqui production}

Tambaqui is probably the best-studied native South American aquaculture species, with many reported studies and published papers. However, it is essential to reflect on how much this research has resulted in practical techniques to boost culture of this species. Concerning reproduction and larviculture, it seems that little progress has been made since the beginning of induced spawning and artificial propagation of tambaqui in the early 1970s through the late $1980^{109,110}$; the techniques and procedures used today are practically the same. The early ${ }^{110,111,123}$ and most recent production manuals ${ }^{27}$ need to be revised to incorporate recent technical advances regarding tambaqui reproduction. This is because most tambaqui hatcheries still work in a traditional fashion to induce artificial reproduction. However, new technologies-such as sperm cryopreservation, sex control, altering the time of sexual maturation, induced sterilization, use of gonadotrophin-releasing hormone analogs, broodstock pit-tagging or monitoring of pedigree to avoid inbred crossings-have not been assimilated into practice by hatchery managers.

Although detailed manipulation of the HPG axis is known for many cultured fish, that is not true for tambaqui, noting that the most commonly used spawn-inducing agent used by fish farmers is still CPE. Although commercial protocols for use of GnRH (Ovopel ${ }^{\circledR}$, Ovaprim and buserelin acetate) are in use by a few fish farms, it is necessary to standardize protocols so that they can be more broadly applied across the industry. Detailed analyses of use of these protocols on the production of viable larvae and the associated costs should be carried out. The formation, selection and maintenance of broodstocks are neglected at most fish farms, and available broodstock management protocols do not adequately address these issues. There is a lack of studies on protocols and optimized conditions for capturing and maintaining high-performance broodstocks (genetics, feed management and nutrition, space, water quality, etc.) focusing on industrial production. As a rule, most fish farmers choose broodfish from among the grow-out stock even without performance evaluation. As a result, many producers do not know how many reproductive cycles a particular male or female broodfish has had and its fry production recorded. Repeated selection of animals that did not respond positively to previous attempts at induced spawning is very common. This lack of control results in low reproductive performance and the need to maintain an exceedingly large number of broodstock. Likewise, it is necessary to update and standardize protocols for tambaqui larviculture, supported by studies on larval physiology and the development and implementation of specific nutritional protocols.

Among biotechnological approaches, those on cryopreservation of tambaqui semen have received most attention by researchers. These protocols still need standardization, and there is still a long way for the semen preserved and maintained in germplasm banks to be applied routinely at fish farms. ${ }^{177}$ The biotechnological approach should apply knowledge of the genetic characteristics of tambaqui broodstock, which is still incipient. Research with feminization and triploidy is limited, and there is still no technology developed for practical use by tambaqui farmers.

While the amount of research carried out on tambaqui is commendable, it is still insufficient to make its culture predictable, profitable and resilient to varying conditions. Most research results never went beyond laboratory scale and are so do not meet the demands of the industry. This core of scientific information needs to be made available to producers so that a more sustainable and profitable tambaqui industry can be realized. Efforts in this direction are being made by researchers from the Brazilian Agricultural Research Corporation (EMBRAPA), and a qualitative leap in the development of protocols for application in fish farming of this species is expected in the coming years. In addition, efforts are needed to transfer these technologies and make them accessible to producers. Likewise, it is necessary to involve several sectors, including fish farms, to support and adopt new technologies and train their technicians with a focus on technical and sustainable industrial production.

\section{4 | GENETICS, GENOMICS AND SELECTIVE BREEDING}

\section{1 | From cytogenetic to DNA studies}

The genetic studies of the so-called 'round characins' date back to the 1980s when cytogenetic characterization of tambaqui (C. macropomum), pacu (Piaractus messopotamicus) (previously Colossoma mitrei) and their interspecific hybrids was reported by Almeida-Toledo et al. ${ }^{181,182}$ (Supporting Information/Infographic 3). This cytogenetic study followed the first attempt to produce an interspecific hybrid 
between tambaqui and pacu. ${ }^{183}$ The development of this hybrid, named 'tambacu', was aimed at combining the high growth rate of tambaqui and the low temperature tolerance of pacu. Similarly, the interspecific cross between two Amazonian characins, tambaqui and pirapitinga (Piaractus brachypomus), named 'tambatinga', was aimed at yielding better-performance offspring. ${ }^{184-187}$ As the hybrids, a 'secondary farmed type', ${ }^{188}$ started being produced in aquaculture, additional cytogenetic investigations were undertaken to understand the biological response and behaviour of chromosomes during mitosis and meiosis. ${ }^{189-192}$

The characterization of wild relatives and confined farmed types of tambaqui using isozymes started during the 1990s. Leitão ${ }^{193}$ used nine isozyme systems to assess the genetic variability of wild and confined populations. ${ }^{194}$ With the passing of time, screening of DNA-based molecular markers led to advances in understanding of intra- and inter-population genetic variation. ${ }^{195}$ As nuclear DNA markers such as microsatellites were developed for tambaqui, ${ }^{196-199}$ new studies of genetic variability within and among tambaqui populations were reported. Three studies were published regarding levels of genetic variability within and genetic structure among wild populations of tambaqui across the Amazon basin, two using partial sequences of the mitochondrial DNA D-loop region and another using microsatellite markers. Using mtDNA, Santos et al. ${ }^{133}$ suggested that that tambaqui forms a panmictic population along the SolimoõesAmazon River channel. On the contrary, Farias et al. ${ }^{200}$ reported significant genetic differentiation $\left(\varphi_{\mathrm{CT}}=0.1209, p<0.001\right)$ between tambaqui populations in the main Amazon basin and in Bolivian subbasins on either side of the Madeira River rapids. A microsatellitebased assessment of landings at three important tambaqui fishery landing ports (Tefé, Manaus and Santarém) showed reasonable mean genetic diversity (expected heterozygosity, $H_{\mathrm{e}}=0.79$ and allelic richness, $A_{R}=8.6$ ), with populations showing a pattern of high gene flow associated with the lack of genetic structure. ${ }^{201}$ Results of these three studies showed no signature of genetic structure between populations sampled within the Amazon basin with either maternally inherited mitochondrial DNA or biparentally inherited microsatellites, suggesting that tambaqui form a panmictic population throughout the Amazon basin.

These results may be driven by the semi-migratory reproductive behaviour and feeding dispersal of the species. However, these studies cannot be entirely conclusive because the concept of 'population' should consider both ecological and demographic paradigms. ${ }^{202}$ Therefore, spawning assemblages should be sampled before mixing at feeding areas, and quantitative criteria and markers with broader genomic coverage, such as single nucleotide polymorphisms (SNPs), should be applied to reveal genetic structure at smaller geographic scales and to assess genomic signatures of local adaptation. ${ }^{203}$ The use of wild tambaqui by local artisanal fisheries and as a raw genetic material for selective breeding programmes depends on the long-term conservation of the wild genetic resources Hilsdorf and Hallerman, ${ }^{204}$ which in turn depends on ongoing and continuing genetic characterization of wild populations throughout its distribution.
When the farming and husbandry of tambaqui started drawing attention outside the Amazon region, broodfish were translocated to other warm Brazilian regions. Thus, propagation of this 'primary farmed type' (Mair \& Lucente ${ }^{188}$ ) has been established to produce fingerlings for local tambaqui farming. The genetic diversity of captive populations maintained in public and private hatcheries was assessed using multiple molecular markers, including random amplified polymorphic DNA (RAPD), ${ }^{192,205,206}$ mitochondrial DNA, ${ }^{207-209}$ inter-simple sequence repeat (ISSR), ${ }^{210}$ microsatellite $208,211-215$ and $\mathrm{SNP}^{216}$ markers. Altogether, it was shown that the genetic resources of farmed tambaqui broodstock in the Amazon region and across other South American regions underwent loss of genetic diversity, which can be attributed to the lack of effective breeding management and founder effects resulting from the species' high fecundity and small number of broodstock utilized.

\subsection{Selective breeding and genomics}

A better understanding of the genetic diversity of wild and captive populations and genetic parameter estimation for aquaculturally important traits are needed for planning an effective selective breeding programme. Despite the importance of tambaqui for South American aquaculture, only a few studies have reported components of variance and genetic parameters for weight at age and morphometric traits. Studying individuals from different fish farms having various degrees of domestication, Mello et al. ${ }^{217}$ showed high estimates a posteriori of mean heritability $\left(h^{2}\right)$ for body weight (0.44 and 0.42) and for daily weight gain (0.49 and 0.40) at 12 and 24 months, respectively. Using groups sourced from another commercial breeder, Perazza et al. ${ }^{218}$ reported moderate-to-high heritability estimates of 0.26 at 221 days and 0.49 at 623 days for body weight, and 0.41 at 623 days for daily weight gain. This study also estimated parameters for a new trait of interest for industrial fish processing, loin eye area (LEA), with $h^{2}=0.39$. These outcomes show significant potential for selective breeding programmes to yield large genetic gains and improved performance. ${ }^{219,220}$ Attempts to develop genetically superior strains for farming purposes have been implemented ${ }^{221}$; however, the advances in understanding of quantitative genetics have not markedly affected commercial tambaqui production, which still relies on non-selectively bred, captively propagated broodstock. Genetically improved strains are not yet commercially available.

Genomics is an interdisciplinary field that uses the tools of molecular genetics and bioinformatics to achieve advances in the understanding of the structure and function of genomes. Genomic tools currently available can address unknown issues of the tambaqui genome and accelerate the process of genetic improvement. For instance, the discovery of individuals lacking intermuscular bones at a fish farm in Brazil opened an avenue of new technological advances, ${ }^{222}$ such as the use of ultrasound as a tool to detect animals lacking intermuscular bones and to measure LEA. ${ }^{222,223}$ Subsequent studies constructed the first high-resolution genetic linkage map of 
a Neotropical fish species using genotyping by sequencing (GBS), ${ }^{224}$ followed by another high-density genetic linkage map for association analysis of sex-linked QTLs ${ }^{225}$ and a genome-wide association study (GWAS) to seek the molecular mechanism underlying lack of intermuscular bones in tambaqui. ${ }^{226}$

Recent studies, including two genome assemblies, have contributed to our understanding of the tambaqui genome. Machado et al. ${ }^{227}$ used RNA-seq technology to generate an extensive liver transcriptome of tambaqui. The authors reported and annotated a total of 43,098 transcripts, which will address issues concerning different facets of tambaqui farming. Ferraz et al. ${ }^{228}$ presented a draft genome assembly for tambaqui and demonstrated its utility for studies of nutritional physiology. The authors focused on metabolism of long-chain (C20-24) polyunsaturated fatty acids (LCPUFA) that are physiologically important nutrients for vertebrates. Previous studies had shown that tambaqui has all the desaturase and elongase enzymes needed to convert C18 polyunsaturated fatty acids into LC-PUFA. Elongation of very-long-chain fatty acid 4 (elovl4) proteins, which participate in the biosynthesis of very-long-chain (>C24) saturated fatty acids (VLC-SFA) and verylong-chain polyunsaturated fatty acids (VLC-PUFA), had not been characterized. Hence, the authors investigated the repertoire and function of two fatty acid elongation genes, elovl $4 a$ and elovl $4 b$. Elovl $4 a$ and elovl $4 b$ have open reading frames of 948 and 912 base pairs, encoding putative proteins of 315 and 303 amino acids, respectively. Functional characterization in yeast showed that both elovl4 enzymes have activity towards all the PUFA substrates assayed $(18: 3 n-3,18: 2 n-6,18: 4 n-3,18: 3 n-6,20: 5 n-3,20: 4 n-6$, $22: 5 n-3,22: 4 n-6$ and 22:6n-3), producing elongated products of up to C36. Moreover, both elovl4 enzymes were able to elongate $22: 5 n-3$ to $24: 5 n-3$, a key elongation step required for the synthesis of docosahexaenoic acid. Other transcriptome investigations are being applied to understand molecular signals leading to sex differentiation in tambaqui (Lobo et al. ${ }^{166}$ ) and differential patterns of expression of Rex6 retrotransposable elements in samples from clear and blackwaters of Amazon rivers, which may help further understanding of insertion and selection sequences in the genome of tambaqui. ${ }^{229}$ In addition, microRNA characterization of tambaqui was carried out to understand the role of these endogenous non-coding riboregulators of gene expression regarding the physiology and expression of traits of aquaculture interest. ${ }^{230}$ Future climate change scenarios predicted by global models may directly affect the long-term survival of wild fish populations and the productivity of farmed stocks. Next-generation sequencing (NGS) tools have made possible studies of the transcriptome, that is the sequences of all messenger RNA molecules, termed RNAseq, in tissues of fish exposed to extreme climate scenarios and to thereby observe differentially expressed genes. Fé-Gonçalves et al. ${ }^{231,232}$ used RNA-seq to show that differentially expressed genes revealed signatures of local thermal adaptation, which will promote understanding of molecular processes putatively underlying responses to climate change, and identified candidate genes for use in marker-assisted selection (MAS).
The growth of tambaqui production has drawn the attention to several potential disease issues in farming operations (see section below on Diseases). As most farmed tambaqui stocks come from unselected stocks, there is unexplored potential for selecting tambaqui for resistance to diseases caused by key pathogens and parasites, as has been shown, for example, for farmed. ${ }^{233}$ The first step to initiate a breeding experiment is to assess whether the targeted trait has phenotypic variation and is heritable, and then to determine how it can be included as a breeding objective. However, unlike growth that is easily measured as weight at age, selective breeding for disease resistance is challenging and complex, given that it is rather difficult to acquire precise and informative disease resistance measurements or related data via controlled challenge experiments or by taking advantage of uncontrolled field outbreaks. Moreover, to avoid compromising biosecurity within the breeding nucleus, fish breeding programmes use disease databases built up from performance of relatives of the selection candidates, as opposed to selection for growth that uses records from the candidates themselves. ${ }^{234}$

Several studies estimating genetic parameters of tambaqui resistance to bacteria and parasites have been published to date. Ariede et al. ${ }^{235}$ carried out a challenge assay with pathogenic Aeromonas hydrophila inoculated intraperitoneally into 576 individuals from 18 full-sib families and registered binary survival (BS) and time of death (TD) within the population. The experiment also assessed whether resistance to $A$. hydrophila is correlated with growth performance in the juvenile phase. Results showed high phenotypic variation, as BS and TD differed considerably among families (BS $=26 \%-89 \%$ and TD = 10.7-69.2 h). Genetic parameter estimates showed moderate values for heritability for BS $(0.17 \pm 0.06)$ and TD $(0.23 \pm 0.09)$. Genetic correlations between resistance to $A$. hydrophila and growth of juvenile of tambaqui did not differ significantly from zero. The authors thus found significant genetic variation for A. hydrophila resistance under moderate genetic control; therefore, selection of superior genotypes is a feasible approach for reducing the impact of this disease in tambaqui culture.

An innovative protocol for evaluating resistance against the parasite Ichthyophthirius multifiliis (ich) was developed by Lira et al. ${ }^{236}$ using thermal oscillations to imitate the primary stressor that naturally precedes outbreaks of this pathogen in tambaqui. Using an experimental cohabitation challenge, the traits evaluated were survival status (SS) and time of death (TD) of fish presenting clinical signs of ich infestation. Total cumulative survival rate differed significantly among families (16-100\%). TD varied from 217 to $254 \mathrm{~h}$ post-cohabitation, a clear sign of significant phenotypic variation for resistance against the parasite. The quantitative genetic analysis demonstrated high values for heritability of SS $(0.46 \pm 0.09)$ and TD $(0.60 \pm 0.18)$. Overall, the genetic estimates suggest that these traits are under strong genetic influence and should respond to selection, which represents a sustainable and effective approach to decrease mortality and improve the production of tambaqui.

Reviews of the literature have shown that heritability for disease resistance in fish tends to vary from moderate to high, which demonstrates the potential of improving this trait by selective 
breeding. ${ }^{237,238}$ Hence, disease challenge experiments to evaluate the genetic basis of resistance of tambaqui to other pathogens, such as Neoechinorhynchus buttnerae and Flavobacterium columnare, would be useful. Results of such assessments would address whether resistance is specific to each disease or general, whether disease resistance is correlated with growth rate, and how disease resistance can be included in a selective breeding programme for tambaqui.

The main hurdles to including disease resistance traits in selective breeding programmes are the high cost of routine disease challenge assays for phenotypic characterization and the difficulty in obtaining data from relatives of the selected candidates, because animals evaluated in disease challenge need to be sacrificed because of biosecurity issues to avoid contamination of the breeding nucleus. This practice decreases the genetic progress for each generation due to the lower accuracy of estimated breeding values (EBVs) when using only sib information instead of the selection candidates themselves. ${ }^{239}$ Therefore, marker-assisted selection (MAS) or genomic selection (GS) become fundamental approaches to disease resistance selection programmes, as recently reported for several aquaculture species. ${ }^{240}$ However, initial studies to understand the genetic architecture or building knowledge of underlying quantitative trait loci (QTL) associated with disease resistance traits in tambaqui are stil needed, particularly genome-wide association studies (GWAS) assessing numerous molecular markers. Therefore, the application of MAS to select candidates based on whether they bear favourable alleles close to large-effect QTL, or using GS to obtain higher prediction accuracy of breeding values for candidates which is based on marker effects estimated in a training population evaluated for both phenotypes and genotypes, is promising approaches. ${ }^{241}$

In total, genetic findings on tambaqui follow the advances of molecular techniques over the years. New approaches take advantage of available DNA technologies for long-read sequencing, designated 'third-generation sequencers'. These new technologies, such as the PacBio sequencer and Nanopore Sequencer, can yield genome assemblies of unprecedented quality. ${ }^{242} \mathrm{~A}$ few draft Neotropical fish genomes have become available, such as those for Astyanax mexicanus, ${ }^{243}$ Arapaima gigas ${ }^{244,245}$ and Pygocentrus nattereri. ${ }^{246} \mathrm{~A}$ high-quality genome assembly and annotation for tambaqui was assembled with PacBio reads and scaffolded with the high-density genetic map, ${ }^{224}$ yielding a highly contiguous assembly; it then was submitted to NCBI for annotation, where it passed all quality checks and subsequently was made available in a genome data viewer for this species. ${ }^{247}$ Added to this was the development of a multispecies SNP array, the Affymetrix SerraSNP array, for two serrasalmid species (Piaractus mesopotamicus and Colossoma macropomum) with validation of $74.17 \%(n=21,963)$ and $71.25 \%(n=21,072)$ of polymorphic SNP variants for the respective species. ${ }^{248}$

Despite the sizeable harvests of farmed tambaqui in Brazil, this represents less than what would be realized by use of a selectively bred strain with better performance, larger LEA, no intermuscular bones, improved disease resistance and other valued traits. Therefore, to achieve international standing as a commodity food, the sector needs to produce fingerlings from highly productive tambaqui strains developed by classical methods of selective breeding and genome-based selection methods to fast-track genetic improvement of this species, conserving wild populations as raw genetic resources for use in further genetic improvement. ${ }^{249}$

\section{5 | NUTRITION AND FEEDING}

Tambaqui is an omnivorous fish, feeding mainly on fruits and seeds from the riparian forest but also on snails, shrimps, insects and small fish $^{2,250}$ (Supporting Information/Infographic 4). Because of its distinctive molariform teeth, tambaqui is well adapted to crumble and ingest seeds and fruits from the jauari (Astrocarium jauari) and the belly spurge (Hevea spruceana, a rubber tree) throughout the rise of river waters in seasonally flooded forests. ${ }^{1,251,252}$ Tambaqui also have branchial gill rakers adapted to rather efficient filtering of zooplankton. ${ }^{3}$

Farmed fish thrive on diets with adequate, balanced macronutrients and energy content, and tambaqui is no exception. ${ }^{253}$ Proteins make up to $65-75 \%$ of farmed animals' dry weight, being the primary nutrients in their diets. ${ }^{254-256}$ The first studies on the dietary protein requirement of tambaqui were carried out by Macedo, ${ }^{257,258}$ which comprises pioneering research on nutritional requirements of the Neotropical round characins. The dietary protein requirement of juvenile tambaqui for optimized growth performance is $22 \%$ crude protein (CP) for fish ranging from 5 to $30 \mathrm{~g}$, and $17 \%$ for fish ranging from 20 to $300 \mathrm{~g}$ live weight. Further studies have defined dietary $\mathrm{CP}$ requirement of tambaqui, with results ranging from 25 to 50 (see Table 3). ${ }^{259-265}$

Vieira et al. ${ }^{266}$ reported highest growth performance under farm conditions for juvenile tambaqui (2.05 9.06 g) fed diets containing $32 \%$ CP. A recent study reported higher growth performance and reduced excretion of nitrogen metabolites for juvenile tambaqui (2 20 g) fed diets containing 30\% CP, ${ }^{267}$ and maximized growth rate for juvenile tambaqui $(6.5 \sim 74.6 \mathrm{~g})$ fed diets containing $29 \%$ digestible protein. ${ }^{268}$

Tambaqui feeding behaviour allows the species to be farmed using diets containing $75-85 \%$ plant protein. However, the inclusion of plant protein in aquafeed formulation and use depends on many variables, such as macronutrient proportions, amino acid composition, animal age and strain, water temperature and content of dietary non-protein energy sources. ${ }^{254,269,270}$ Rodrigues $^{271}$ reported that results of studies on dietary protein requirements of fish between 1979 and 2012 showed significant divergences, which results not only from the virtual lack of knowledge on biological and nutritional value of the non-protein energy sources and the energy-to-protein ratios of diets but possibly also from the role of genetic variability-driven responses (Tave ${ }^{272}$ ), given that tambaqui has been used in intensive farming systems for no more than a few decades, selective breeding programmes for the species are still few, and no solid results have been reported to date. Further, experimental conditions evolved markedly within this period, which 
TAB LE 3 Dietary protein requirements with dietary energy levels for tambaqui (Colossoma macropomum)

\begin{tabular}{|c|c|c|c|c|}
\hline Weight range ${ }^{a}(g)$ & $\begin{array}{l}\text { Protein requirement } \\
\mathrm{g} \mathrm{kg}^{-1}\end{array}$ & $\begin{array}{l}\text { Energy level } \\
\text { kcal kg }^{\mathrm{d}}\end{array}$ & $\begin{array}{l}\text { Energy-to-protein ratio }{ }^{\mathrm{h}} \\
\text { kcal g }^{-1}\end{array}$ & Reference \\
\hline $2.0-9.0$ & $320^{b}$ & - & - & 266 \\
\hline $0.44-30.6$ & $316^{\mathrm{b}}$ & $3000^{e}$ & $9.5: 1$ & 264 \\
\hline $1-50$ & $481^{b}$ & $4585^{e}$ & $9.4: 1$ & 260 \\
\hline $6.5-174.5$ & $290^{c}$ & $3300-3324^{f}$ & $11.4-11.5: 1$ & 268 \\
\hline $30-145$ & $300^{b}$ & $2700^{e}$ & $9.0: 1$ & 259 \\
\hline $30-250$ & $250^{b}$ & $3100^{g}$ & $12.4: 1$ & 261 \\
\hline $46-75$ & $300^{\mathrm{b}}$ & $3860-4040^{f}$ & $12.9-13.5: 1$ & 265 \\
\hline $50-100$ & $360^{b}$ & $3407^{e}$ & 9.5: 1 & 263 \\
\hline
\end{tabular}

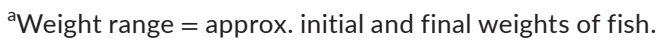

${ }^{\mathrm{b}}$ Crude protein.

${ }^{c}$ Digestible protein.

${ }^{\mathrm{d}}$ Energy levels of diets.

${ }^{\mathrm{e}}$ Digestible energy.

${ }^{f}$ Gross energy values.

${ }^{g}$ Metabolizable energy values.

${ }^{\mathrm{h}}$ Calculated.

may have affected the results of trials. This uncertainly emphasizes the importance of continuing studies on nutrition for the species, especially regarding selection of feed ingredients based upon results of digestibility trials.

Considering that fish do not have specific dietary protein requirements, but rather need a balanced pool of dietary essential amino acids, ${ }^{254,255}$ experimental trials based upon the concept of ideal protein ${ }^{273}$ or, as currently redefined, the essential nitrogen concept are fundamental for the advancement of knowledge on the nutrition and feeding of tambaqui. In this regard, Lima et al. ${ }^{274}$ reported that it is possible to reduce dietary protein contents from 32 to $24.5 \%$ if the diet of postlarvae tambaqui $(0.44 \mathrm{~g})$ is supplemented with a balanced pool of essential amino acids. In the same line of research, Marchão et al. ${ }^{275}$ reported that juvenile tambaqui ( $22.9 \mathrm{~g}$ ) require $1.58 \%$ dietary lysine, that is diets containing $5.7 \%$ lysine within the crude protein. Bonfim et al. ${ }^{276}$ recommended $0.323 \%$ of digestible tryptophan in diet for the maximum deposition of body protein.

Energy is not a nutrient by definition, but it plays a key role in fish nutrition because of its biochemical and physiological importance to maintenance, growth and reproduction of animals. ${ }^{277,278}$ The determination of the optimal dietary energy level and its correlation with dietary protein content is fundamental for optimizing practical fish nutrition and feed management, given that dietary energy deficiency can lead to use of protein as energy source. ${ }^{279,280}$ On the contrary, excess dietary energy reduces feed consumption and, consequently, ingestion of nutrients. ${ }^{255}$ In a review on nutritional requirements of tambaqui, Guimarães \& Martins ${ }^{281}$ pointed out that the species has great ability to use various non-protein energy sources and a tendency to increase body fat deposition. While a protein sparing effect driven by manipulation of dietary energy sources, mainly carbohydrates, is well documented for many fish, it has not been demonstrated for tambaqui.

Understanding of metabolic interactions between proteins, lipids and carbohydrates is key to evaluating the dietary lipid requirement of fish. That is, the dietary lipid requirement and use by fish depend on the content and quality of other dietary macronutrients, and no clear, precise definition of tambaqui's dietary lipid requirements is available. However, Camargo et al. ${ }^{282}$ reported a linear response to increasing levels of dietary, metabolizable energy $(2,850-3,300 \mathrm{kcal}$ $\mathrm{EM} \mathrm{kg}{ }^{-1}$ ) on growth performance of juvenile tambaqui (30.17 g), suggesting the highest values, $12.50-13.75 \mathrm{kcal} \mathrm{EM} \mathrm{g}^{-1}$, as the dietary energy requirement of the species. Oliveira et al. ${ }^{283}$ reported a protein requirement of $30 \%$ crude protein (CP) and an energy-toprotein ratio around $9.0 \mathrm{kcal}^{\mathrm{DE} \mathrm{g} \mathrm{CP}} \mathrm{CP}^{-1}$ for juvenile tambaqui (1.0$125.0 \mathrm{~g}$ live weight).

Even though only a few studies report specific, dietary fatty acid requirements of tambaqui, such studies highlight that total lipid and fatty acid composition varies greatly between wild and farmed fish and that dietary fatty acids play a key role in growth, flesh quality and disease resistance of the species. ${ }^{281,283}$ For instance, tambaqui fed varying dietary linoleic-to-linoleic acid (LA/ALA) ratios had no significant effects on growth, but significantly influenced carcass fatty acid deposition. ${ }^{284}$ This study also reported that tambaqui can elongate and desaturate linoleic acid (LA, 18:2n-6) and linoleic acid (ALA, 18:3n-3) to their corresponding long-chain polyunsaturated fatty acids, such as arachidonic acid (ARA, 20n:4-6), eicosapentaenoic acid (EP, 20:5n-3) and docosahexaenoic acid (DHA, 22:6n-3), 
as has been reported for most freshwater fish. Results of a recent molecular study demonstrated that tambaqui express all desaturase and elongase activities (ie fads2, elol5 and elovl2) required to convert LA and ALA to ARA, EPA and DHA. ${ }^{228,285}$ Thus, the NRC ${ }^{255}$ recommendations of supplying 5-20 $\mathrm{g} \mathrm{LNA} \mathrm{kg}^{-1}$ diet (based on total lipid content) and the importance of $n-6$ fatty acids in the nutrition and feeding of Neotropical fish species such as tambaqui are supported.

Non-protein feed ingredients rich in carbohydrates and lipids can be used to increase dietary energy content, attaining optimal energy-to-protein ratio. ${ }^{286}$ Because of the importance of balance between these dietary macronutrients in fish production and metabolic pathways, de Almeida et al. ${ }^{287}$ and Sandre et al. ${ }^{288}$ evaluated, respectively, dietary protein-to-lipid and carbohydrate-to-lipid ratios for tambaqui and demonstrated that the species exhibits highest survival and growth when fed diets containing carbohydrate levels close to $40-46 \%$.

Optimized productivity, maximization of profits and reduction in environmental impacts of commercial fish farming rely on the knowledge of coefficients of digestibility of ingredients used in formulation of fish diets, and tambaqui is no exception. ${ }^{255,289,290}$ Buzollo et al. ${ }^{291}$ studied the apparent digestibility coefficient (ADC) of protein and energy of ingredients ordinarily used to formulate commercial diets for tambaqui and reported that corn gluten has high apparent digestibility coefficients for crude protein ( $A D C_{C P}$ ) (98.09\%) and gross energy ( $\mathrm{ADC}_{\mathrm{GE}}$ ) $(96.91 \%)$. Corn meal $(94.5 \%)$ and wheat bran (86.08\%) presented the highest $A D C_{C P}$ of all dietary energy sources. Regarding dietary lipid sources, corn oil (95.7\%), fish oil (93.61\%), soya bean oil (93.31\%) and corn meal (88.70\%) presented the highest $\mathrm{ADC}_{\mathrm{GE}}$. Tambaqui juveniles efficiently use the amino acids of protein and energy-rich ingredients. Corn meal and wheat bran presented high ADCs for total amino acids, 95 and $92 \%$, respectively. Regarding dietary protein sources, corn gluten meal and soya bean meal presented the highest ADCs for tambaqui, 97.6 and $96.6 \%$, respectively (Table 4). ${ }^{292}$

The natural foods of tambaqui are very rich in vitamins and minerals, and tambaqui farming is prevalent in regions with waters of high primary productivity. This may suggest why studies on dietary requirements of minerals and vitamins of tambaqui are scarce; that is, no dietary vitamin or mineral deficiency signs have been reported for pond-farmed tambaqui. Oliveira et al. ${ }^{283}$ and Guimarães $\&$ Martins ${ }^{281}$ reviewed reported information on vitamin and mineral requirements of tambaqui, but such reports are based on few studies. As for most teleosts, most studies target ascorbic acid requirements. ${ }^{293}$ Chagas \& Val, ${ }^{294}$ for instance, evaluated the effect of L-ascorbic acid on the productive performance and haematological parameters of juvenile tambaqui and reported that $100 \mathrm{mg} \mathrm{kg}^{-1}$ was sufficient to maximize production and maintain homeostasis. Aride et $\mathrm{al}^{295}$ studied the relationship between acid ascorbic and iron in diets for tambaqui and reported that the supplementation of acid ascorbic improved haematological parameters and tissue absorption of iron and that iron deficiency resulted in highly predictable anaemia. Sousa ${ }^{296}$ tested increasing digestible phosphorus levels in diets for small juvenile tambaqui $(0.51 \mathrm{~g})$ and recommended inclusion of $0.71 \% \mathrm{P}$ in diets, which corresponds to an estimated level of $1.04 \%$ of total dietary $P$.

The search for alternative feed ingredients, which can support higher performance and reduce production costs, is a major constraint for the fish feed industry, especially in the Amazon region. The use of locally available feed ingredients can improve diet (feed) efficiency and boost economic viability for farming and husbandry of tambaqui. ${ }^{252}$ Most studies on alternative dietary feed ingredients for tambaqui evaluated only the chemical composition and substitution of conventional by alternative ingredients focusing on the animals' production. However, the evaluation of the digestibility coefficients of ingredients, independently of origin and nutritional contribution, is fundamental for enabling use of alternative ingredients in aquafeeds. In that regard, Silva et al. ${ }^{297}$ evaluated the ADC of palm kernel (Elaeis guineenses) meal by-product for tambaqui in two weight classes, 4.4 and $115.2 \mathrm{~g}$, and reported an $\mathrm{ADC}_{\mathrm{CP}}$ of $63.29 \%$. Silva et al. ${ }^{298}$ determined the ADC of whole banana meal in diets for tambaqui (100.3 g) and reported ADC above $90 \%$ for protein, gross energy and dry matter with the inclusion of up to $8 \%$ of the ingredient in the diet (Tables 5 and 6).

The steady growth of aquaculture production in Brazil has encouraged feed mills to manufacture species-specific diets for the farming and husbandry of native species. However, despite the high number of feed mills producing fish feeds, ${ }^{306}$ most formulated and processed diets claim to meet 'round characins' feeding and nutritional requirements, including tambaqui and pacu-Piaractus mesopotamicus-and their reciprocal hybrids. Only one brand is commercially available and labelled as specifically formulated for tambaqui. Despite the benefits to tambaqui production resulting from availability of manufactured diets, the feed formulae are usually kept as proprietary information by feed companies, making difficult the comparison of performance of fish on a nutrient content meeting requirements-based approach.

Feeding and nutrition are the major costs associated with farming of any fish. From the very first attempts to study nutritional requirements of tambaqui 40 years ago, studies on the nutrition of the species targeted dietary protein requirement of fingerlings and juveniles, and the results were not consistent. As of the early 2000s, studies on amino acid requirements have gained emphasis, but are still incipient. Trials on the use of feed additives, such as digestive enzymes, digestibility and use of alternative feedstuffs, have been carried out, but information on physiological mechanisms underlying nutrient absorption and use remains scarce at best. Tambaqui has peculiar feeding habits and nutritional requirements, so additional, targeted investigations are needed to develop cost-effective diets for each life stage to increase the economic viability and sustainable development of tambaqui farming. 


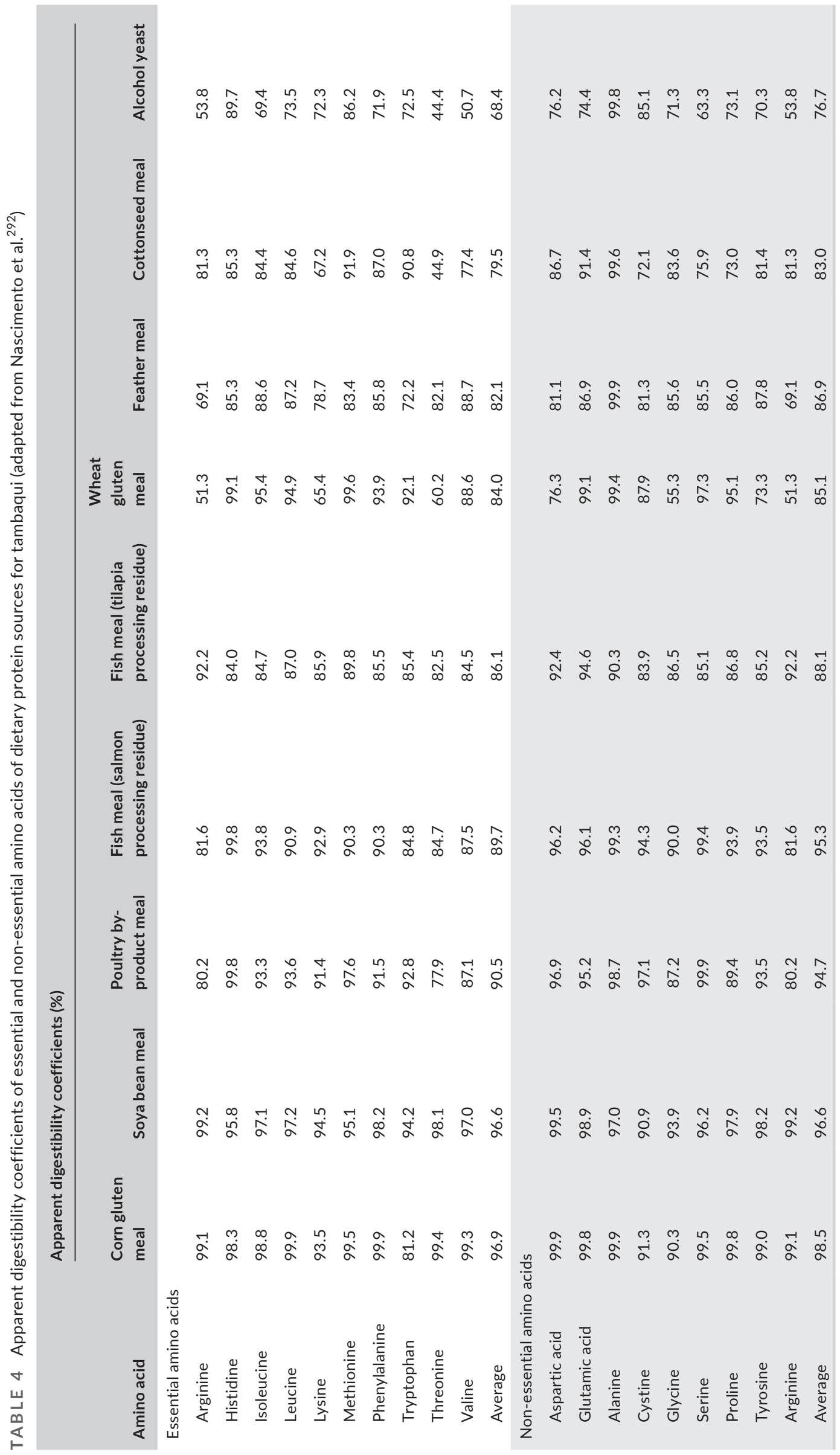


TAB LE 5 Digestibility coefficient of selected feed ingredients for tambaqui (Colossoma macropomum)

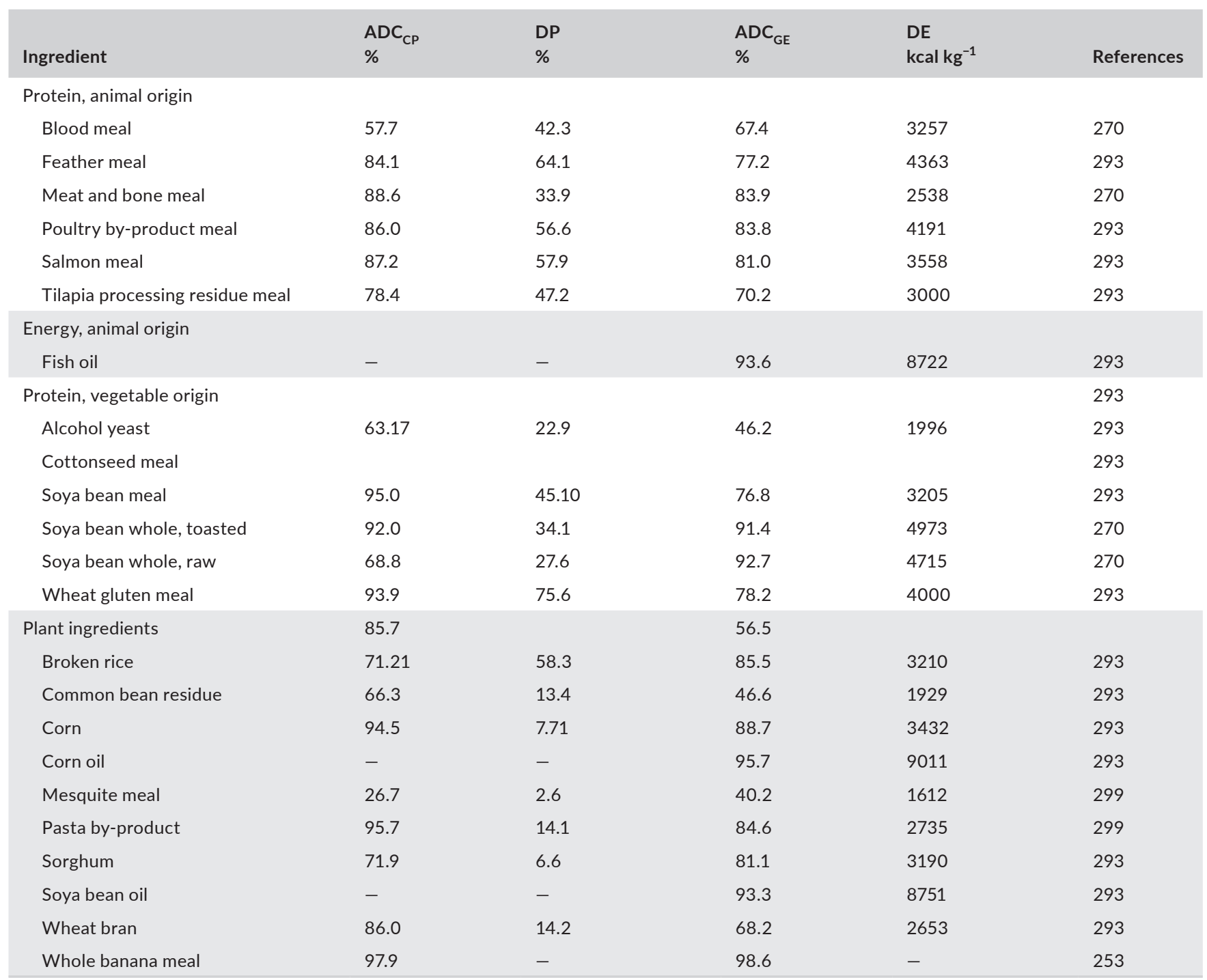

Abbreviations: $\mathrm{ADC}_{\mathrm{CP}}$, apparent digestibility coefficient for crude protein; $\mathrm{ADC}_{\mathrm{GE}}$, apparent digestibility coefficient for gross energy; $\mathrm{DP}$, digestible protein; DE, digestible energy.

TAB LE 6 Alternative feedstuffs tested for tambaqui (Colossoma macropomum)

\begin{tabular}{|c|c|c|c|c|}
\hline Alternative feedstuff & $\begin{array}{l}\text { Average initial weight } \\
\text { (g) }\end{array}$ & Level of inclusion (\%) & Replaced ingredient & Reference \\
\hline Licuri meal (Syagrus coronata) $^{a}$ & 3.1 & $100 \%$ & Corn & 300 \\
\hline Cassava (Manihot esculenta) & 10.6 & 15 or $45 \%$ & - & 301 \\
\hline Pejibaye (Bactris gasipaes) meal ${ }^{a}$ & 32.4 & $100 \%$ & Corn meal & 302 \\
\hline Leucaena leaf (Leucaena leucocephala) meal & 41.1 & $24 \%$ & - & 304 \\
\hline
\end{tabular}

${ }^{\text {a }}$ Percentage of replacement.

\section{6 | DISEASES AND HEALTH MANAGEMENT}

Most pathogens affecting tambaqui farming operations have been found in wild specimens collected from Amazonian lakes and rivers. $^{307-309}$ (Supporting Information/Infographic 5).
Nevertheless, outbreaks of acute mortality associated with pathogens have not been reported for wild tambaqui populations. This section discusses the pathogen-host relationship and the impact of prevalent parasitic and bacterial diseases of tambaqui in farming environments. 


\section{1 | Parasites}

\subsubsection{Neoechinorhynchus buttnerae}

The acanthocephalan Neoechinorhynchus buttnerae is regarded as the most relevant pathogen of farmed tambaqui. ${ }^{310,311}$ The life cycle of this parasite involves the presence of an intermediate host (zooplankton) and a definitive host (tambaqui). ${ }^{312}$ Outbreaks of this parasite do not cause sizeable mortalities, but do cause economic losses to farming, ${ }^{313,314}$ because parasitized fish continue to feed normally, but nutrients are sequestered and used by the helminth, hampering feed conversion rate and growth of the fish. The parasitized tambaqui does not show change in behaviour or evident clinical signs, but disease diagnosis is simple and easy for N. buttnerae, as it is a macroparasite detectable by the naked eye inside the fish intestine, so routine health monitoring at the fish farm is necessary. Critical control points for the prevention of acanthocephalosis at tambaqui farms are as follows: (i) acquisition of acanthocephalan-free fish with a sanitary certification; (ii) a water source free of tambaqui, which is the natural host for this acanthocephalan; and (iii) implementation of careful preventive measures between production cycles by drying and disinfecting the ponds.

Recent in vitro studies have reported the potential of natural plant extracts ${ }^{315}$ organic acids, essential oils ${ }^{316}$ and oleoresins $s^{317}$ to kill the acanthocephalan, and in vivo studies have shown that a commercial phytobiotic ${ }^{318}$ and plant essential oils ${ }^{319}$ have reduced the burden of parasitism at different levels. Recent in vitro studies have reported the potential of natural plant extracts, ${ }^{315}$ organic acids, essential oils ${ }^{316}$ and oleoresins ${ }^{317}$ to kill the acanthocephalan, and in vivo studies have shown that a commercial phytobiotic $^{318}$ and plant essential oils ${ }^{319}$ have reduced the burden of parasitism at different levels. However, there is still no consensus on the effectiveness of acanthocephalosis control in farmed tambaqui based only on fish medication, mainly because it is a disease caused by infected zooplankton that are dispersed threedimensionally throughout the farming environment, making disease prevalence and relapse imminent if preventive measures are not in effect.

\subsection{2 | Ichthyophthirius multifiliis}

The ciliated protozoan Ichthyophthirius multifiliis is among most important parasites of farmed fish, causing massive mortality in farming operations worldwide, ${ }^{320,321}$ including tambaqui farms. ${ }^{157}$ Predisposing factors for mortality have long been known, including stress due to sudden environmental changes, especially water temperature, which lead to failure of the fish immune system. ${ }^{320}$ This parasite is relevant to tambaqui farming mainly when it is farmed outside of its environmental comfort zone, that is a region of stable, warm climate. During health monitoring of 20 fish farms in the Amazon region between 2018 and 2020, no I. multifiliis outbreaks were reported at tambaqui farms (G.R.M. Valladão,
Laboratório de Parasitologia e Patologia de Organismos Aquáticos, Universidade Nilton Lins, Manaus, Brazil; unpublished data). In contrast, a study carried out at the same time period reported the importance of ichthyophthiriasis in tambaqui farmed outside the Amazon region. ${ }^{236}$

Ichthyophthiriasis, or white spot disease (of fish), is characterized by high morbidity and mortality rates, and is the leading cause of fish death related to respiratory collapse. However, it is also common to find secondary systemic bacterial infections in intensely parasitized fish. Several molecules have been studied in different fish for treatment of this parasite. ${ }^{26,322}$ However, fish farmers and professionals have not been able to apply recommended treatments to ponds because of the lack of registration of medications for aquaculture purposes. Nonetheless, late diagnosis at fish farms hampers the effectiveness of chemical treatments. Therefore, white spot disease is a seasonal and regional concern for the tambaqui farming industry, given the low resistance of the species to ichthyophthiriasis in regions with broad thermal variation or abrupt change of seasons. Effective, innovative prevention and control strategies for this tambaqui parasite are an immediate need.

\section{2 | Monogenoidea}

Monogenoid parasites plague almost all marine and freshwater farmed fish worldwide, wild and farmed tambaqui included, especially in Brazil and Peru. ${ }^{323-328}$ Monogeneans mainly affect tambaqui gills, which is problematic because respiratory collapse is the main cause of fish mortality caused by parasites. The prevalence of monogeneans in tambaqui farming environments is close to $100 \%$ Godoi et al., ${ }^{329}$ and the intensity of parasitism varies with environmental factors. Warmwater fish farming generally is carried out under low dissolved oxygen contents, and the host-parasite relationship may vary greatly with water temperature, parasite load and management practices. Thus, fish having even a light gill parasite infestation may be prone to mortality due to respiratory collapse.

In one of the few studies associating the impact of climate change with tambaqui diseases, Costa $\& \mathrm{Val}^{330}$ reported that the rate of parasitism by monogeneans rapidly increased in the extreme climate change scenario; rise in temperature and carbon dioxide is predicted to affect the monogenean-tambaqui relationship. Recent studies report promising effects of different treatment protocols against monogenean infection in tambaqui. ${ }^{331-333}$ However, none of the treatments has reached the market as a registered product for the species.

\subsection{1 | Perulernaea gamitanae}

The crustacean Perulernaea gamitanae (Lernaeidae) was described for the first time parasitizing wild tambaqui in the Amazon River near Iquitos, Peru. ${ }^{309}$ P. gamitanae shows high host specificity to tambaqui and its hybrids. ${ }^{334-336}$ and high specificity of the 
infection site to the oral and opercular cavities. This parasitosis does not affect feed consumption or growth performance of affected fish, but decreases the post-harvest quality of fish products, which present haemorrhagic areas in the oral cavity and adjacent region. ${ }^{337}$ Tambaqui is commercialized as whole fish or in halves ('bandas') with heads (see section on Processing methods). Therefore, the presence of macroscopic parasites and lesions in the product displeases consumers. Treatment of crustacean parasites in aquaculture is usually carried out using pesticides, for example diflubenzuron. ${ }^{338,339}$ However, the impact of use of such molecules on fish health and the consumer is little known, and therefore, pesticide use is not advisable. Removal of heads of fish at processing is the only strategy to sell tambaqui infected by $P$. gamitanae because this parasite occurs only in the oral cavity and is not zoonotic, thereby not affecting food safety. Nonetheless, additional studies are needed to better understand the pathogenesis of infestation and to develop prevention strategies.

\section{3 | Myxozoans}

This group of parasites, which is diverse and well known because they cause outbreaks throughout global aquaculture, includes the genera Myxobolus sp., Myxidium sp., Sphaerospora sp. and Henneguya sp. $^{340}$ Myxosporeans have been routinely detected in both wild and farmed tambaqui. ${ }^{341-343}$ However, little is known regarding harmful effects of parasitism by myxosporeans and how these parasites cause mortality in South American fish. Videira et al. ${ }^{343}$ detected a severe infection by myxosporeans at a tambaqui farm during a mortality outbreak; however, the parasites were not proven as the causative agent of mortality. Between the years 2018 and 2020, numerous myxosporeans have been detected on farms during monitoring of tambaqui health without a history of mortality, clinical signs or behavioural changes (G.M.R. Valladão, G.R.M. Valladão, Laboratório de Parasitologia e Patologia de Organismos Aquáticos, Universidade Nilton Lins, Manaus, Brazil; unpublished data). Therefore, studies on the pathogenicity of myxosporeans are to determine which species of this vast group of parasites are relevant to tambaqui and to provide the basis for prevention and control methods.

\section{4 | Bacteria}

\subsection{1 | Flavobacterium columnare}

Flavobacterium columnare causes the common columnaris disease of several farmed fish worldwide ${ }^{344}$ and has been isolated from farmed tambaqui presenting whitish, integumentary lesions. ${ }^{345,346}$ Although F. columnaris had proven to be one of the most relevant and harmful diseases for tambaqui, associated with mortality outbreaks after transport or handling of young fish, only recently has the Koch postulate been fulfilled for this species. ${ }^{347}$ After complaints from producers and analysis of tambaqui mortality outbreaks in recent years (2018 to 2020; G.M.R. Valladão, Laboratório de Parasitologia e Patologia de Organismos Aquáticos, Universidade Nilton Lins, Manaus, Brazil; unpublished data), the stress of handling young fish associated with the loss of scales caused by seines is recognized as a factor predisposing them to columnaris disease outbreaks up to $96 \mathrm{~h}$ after transport. Effective prevention strategies, such as adding $0.8 \%$ sodium chloride to transport water, are thus necessary to control columnaris infection. ${ }^{347}$ On the contrary, addition of antibiotics or chemotherapeutants to transport water has not been shown effective to prevent columnaris disease and mortality. To date, there are no vaccines nor commercial treatments registered for the control of bacteriosis in general in tambaqui farming operations, a problem that needs to be addressed.

\section{5 | Motile Aeromonads}

The occurrence of haemorrhagic septicaemia caused by several Aeromonas species is common in farmed fish worldwide, ${ }^{348-350}$ including tambaqui. ${ }^{351}$ However, few studies of the pathogenesis of different Aeromonas species in tambaqui are available. Recently, Gallani et al. ${ }^{351}$ fulfilled Koch's postulates for A. hydrophila isolated from the kidney of infected tambaqui. The same postulates were applied to the other two aeromonads, A. jandaei and A. caviae, isolated from infected tambaqui, corroborating that haemorrhagic septicaemia spreads among healthy fish. ${ }^{347}$ Indeed, several aeromonads ( $A$. dhakensis, A. caviae, A. veronii, A. hydrophila and A. jandaei) with pathogenic potential were isolated from tambaqui gills and described by Fernando-Ramos et al. ${ }^{352}$ Aeromonads are opportunistic bacteria ordinarily found in the aquatic environment and soil; hence, stressful management of fish, poor environmental quality and primary diseases are predisposing factors for haemorrhagic septicaemia. Tambaqui infected by A. hydrophila can present darkened skin, ulcers, haemorrhage, lethargy, hypo/anorexia and different degrees of mortality at different life stages. ${ }^{351}$ While several synthetic and natural disinfectants and antibiotics show promise for controlling this bacteriosis (Gallani et al. ${ }^{351}$ ), there are no registered products available on the market for prevention (eg a vaccine) or specific treatment for tambaqui.

In summary, the production of tambaqui can be affected by important pathogens, many of which are already known around the world. However, treatment of diseases is one of the leastdeveloped areas of tambaqui culture, which calls for attention from the veterinary pharmaceutical industry and regulatory agencies in producer countries. Based on considerations of the pathogenhost relationship, climate change and anthropogenic changes in the aquatic environment can affect the natural response of tambaqui to pathogens, which can contribute to occurrence of outbreaks and emergence of new diseases. Prevention and control based on safe, effective methods still need to be developed for the main pathogens of tambaqui. Moreover, successful selective breeding programmes, especially those that incorporate genomic data, likely can result in cumulative and permanent improvement 
of pathogen resistance in tambaqui, similar to other cases in model and aquaculture species. ${ }^{233,241,353}$

\section{7 | PROCESSING METHODS}

Tambaqui is traditionally commercialized as a whole, fresh or frozen product, and has high acceptance by the consumer market. ${ }^{76}$ (Supporting Information/Infographic 6). Even in markets outside the Amazon basin, tambaqui products attract consumer interest because of its high quality and unique gastronomic qualities. Over recent decades, many studies have contributed to post-harvest processing technologies for tambaqui. During the 1980s and 1990s, studies focused on evaluating the chemical composition of whole tambaqui, fillet, ribs, mid-sagittal plane cut with head, processing of by-products, and mechanically separated meat (MSM), also called 'fish pulp'.

Castelo et al. ${ }^{40}$ assessed the chemical and physical-chemical characteristics of abdominal fat and compared them with those of intramuscular fat. Palmitic, oleic and stearic acids were the primary fatty acids found, which varied quantitatively and qualitatively according to the time of year when slaughter took place. The authors also found a substantial increase in saturated fatty acids after deodorization and the development of rancidity. The abdominal fat was thermally unstable and that the deodorization process led to the destruction of natural antioxidants. Comparing abdominal fat with soya bean oil used in the frying of potato chips, sensory evaluation and consumer acceptance did not show a statistical difference, indicating the potential use of deodorized tambaqui abdominal cavity fat for cooking purposes. Ortíz \& Bello ${ }^{354}$ evaluated the composition and stability of tambaqui fatty acids in mechanically separated meat (MSM) during frozen storage. At highest concentration was palmitic acid observed, followed by oleic acid. Further, tambaqui MSM is rich in omega-6 polyunsaturated fatty acids (linoleic and arachidonic) content. The fatty acids were affected by storage temperature, with the highest values of free fatty acids observed at 4 months of storage at $-10^{\circ} \mathrm{C}$. The authors stressed that MSM is a sustainable and profitable way of using processing waste, yielding nutritional quality equivalent to red meat. However, further studies would be needed to ensure its stability. During storage, losses in the functionality of proteins, enzymatic and bacterial deterioration, and formation of various volatile compounds may occur, which can cause oxidative rancidity, among other problems.

Aguiar $^{355}$ assessed the nutritional composition of regional Amazon foods to help regional diet development. Raw tambaqui fillet presented $66.3 \%$ moisture, $24.8 \%$ protein, $3.1 \%$ ash, $5.8 \%$ lipids and $151.4 \mathrm{kcal} / 100 \mathrm{~g}$ of energy. Whole tambaqui presented $72.7 \%$ moisture, $19 \%$ protein, $1.4 \%$ ash, $6.9 \%$ lipids and $138.10 \mathrm{kcal} / 100 \mathrm{~g}$ of energy. Izquierdo et al. ${ }^{356}$ showed that all essential amino acids are present in the meat of tambaqui. The main minerals found were phosphorus, calcium, and, to a lesser extent, iron. These authors reinforced the point that the nutritional composition of tambaqui products may vary depending on the fish's diet, sex, habitat, age and size.
These first investigations of tambaqui fillet and carcass nutritional values during the 1980 s to the 2000 s focused on the tambaqui originating from fisheries, and to a lesser extent from cultivation commercialized mostly at the regional market. As tambaqui farming expanded and other markets were opened, new tambaqui product conservation technologies were investigated. Almeida et al. ${ }^{357}$ evaluated the useful life of tambaqui preserved on ice, performing a sensory analysis of raw and cooked fish over time. Raw fish retained superior quality (Class A) for 22 days. If cooked, products remained Class $A$ for 31 days. Both raw and cooked products remained in sound quality (Class B) for up to 40 days. At 43 days, both achieved 'quality of current consumption', and at 49 days, they were considered putrid. These outcomes certified that tambaqui can be conserved and traded for 40 days after slaughter if kept between layers of ice. The $\mathrm{pH}$ and the total volatile nitrogenous bases (N-BVT) of the muscle increased with the storage time, showing these parameters to be adequate indices to determine product quality. The authors pointed out that the variation in useful life span would also depend on capture and storage conditions.

The studies so far focused on conservation of tambaqui products in natura on ice for quick post-harvest commercialization. However, increased demand for tambaqui products led to search for new tambaqui products. For instance, Izquierdo et al. ${ }^{358}$ and Sleder et al. ${ }^{359}$ developed sausages using mixtures of tambaqui MSM. The authors found that the higher the proportion of mechanically separated meat, the greater the fat content and, concomitantly, the greater the amount of essential fatty acids. In the sensory evaluation, the formulation containing the highest amount of tambaqui MSM was the most accepted, evidencing the possibility of using tambaqui processing residue to develop new products.

In addition, other value-added tambaqui products became strategic for market expansion. Cartonilho \& Jesus ${ }^{360}$ evaluated different cuts of tambaqui, such as ribs, loin, and steak, stored frozen at $-25^{\circ} \mathrm{C}$ in polyethylene packages for 180 days. The yields obtained were $19.6 \%$ for ribs, $27.7 \%$ for the loin, and $16.4 \%$ for steak. The loin and steaks cuts were classified as low fat, and the rib cut as semi-fat, according to the classification proposed by Ref. 361 Thiobarbituric acid reactive substances (TBARs) values increased over the storage period and showed higher lipid oxidation in the fatter cut (rib). Thus, only lowering the storage temperature was not enough to prevent the process of lipid oxidation from developing, suggesting that storage in vacuum packaging could be an alternative. Bearing in mind full use of tambaqui processing residues, Leitão ${ }^{362}$ developed a method to obtain flour from the skin. This by-product was nutritionally evaluated for use in food products. Bread, toasts and cookies were made with $10 \%$ tambaqui skin flour to replace wheat flour to increase these foods' protein content and were well accepted.

Mechanically separated meat from tambaqui was used by Kato et al. ${ }^{363}$ to prepare nutritious rice, pasta, salad and pie. The authors evaluated the acceptance of these products by students at a primary school to supply part of the students' daily nutritional needs 
and to favour the formation of good eating habits by students, with economic valuation of local ingredients. The results showed high acceptance rates (57.5-94.4\%), demonstrating that mechanically separated meat of tambaqui is an efficient way to incorporate fish into school meals. The authors also emphasized the need for the implementation of nutritional education programmes aimed at incorporation of fish products.

Increasing consumer demand for healthy and ready-to-eat products opened opportunities to develop new tambaqui products to boost consumption and enter new markets. The sous vide technique (controlled cooking under vacuum, resulting in a ready-to-eat product) has shown great potential. Ramos et al. ${ }^{364}$ evaluated quality parameters of sous vide products of tambaqui raised in cages. Tambaqui raw material was prepared using basil sauce and $5 \%$ sodium lactate treated under pasteurization in a water bath at $65^{\circ} \mathrm{C}$ for $12.5 \mathrm{~min}$ followed by rapid cooling in water at $0^{\circ} \mathrm{C}$ and storage under refrigeration. Results showed that sous vide preparation of tambaqui reduced coliforms at $45^{\circ} \mathrm{C}$ and psychrotrophic microorganisms, extending product shelf life.

Currently, the perception of consumers regarding animal farming has been changing. Concern about animal welfare regarding pre-slaughter and slaughter practices is an emerging issue. There is need for studies on pre-slaughter procedures, which could directly interfere with rigour mortis and increase the fish product's shelf life. Mendes et al. ${ }^{366}$ evaluated the advantages of recovery from pre-slaughter stress in tambaqui. The fish were placed into ponds to recover from the stress of transportation for $48 \mathrm{~h}$, and then were slaughtered by asphyxia and hypothermia. Analysis after slaughter showed that N-BVT content and $\mathrm{pH}$ were higher in fish slaughtered by asphyxiation. Sensory analyses indicated that quality of fish products slaughtered just after transport was lower than that for fish that recovered from pre-slaughter stress. Thus, post-transport recovery contributes to preserving the freshness and quality of tambaqui slaughtered on an industrial scale. Further study would be needed, however, to determine the economic viability of this recommendation.

There has been a trend of seeking complete utilization of all residues from fish processing. Thus, use of tambaqui waste has be explored to add value to so-called 'low-value products'. Silva et al. ${ }^{367}$ carried out a trial using head, skin and bones to extract collagen. The process yielded high-quality gelatine, a valuable multifunctional in gredient used in foods, pharmaceuticals, cosmetics and photographic films. This process turns out to be a profitable and environmentalfriendly process for utilizing tambaqui processing residues.

The nutritional quality of fish products has aroused concerns for consumers, leading to changes in production practices mainly associated with fish feeding. Cortegano et al. ${ }^{368}$ assessed the effect of supplementing the ration with Schizochytrium sp. microalgae flour on the composition and fatty acid content of tambaqui meat, comparing them with those obtained when using a non-supplemented ration. The authors observed no difference in the gross composition of fish meat. However, there was an increase in long-chain polyunsaturated fatty acid content from the omega- 3 series, docosahexaenoic acid
(DHA) from 14.81 to $38.60 \mathrm{mg} / \mathrm{g}$, and an increase in the omega-3: omega-6 ratio from 0.16 to 0.51 in fish meat. This study showed the possibility of marketing a sustainability-oriented product with greater nutritional value.

The search for healthier and less-formulated foods has contributed to the commercialization of fish fillets due to their high nutritional value and easier preparation. However, shorter shelf life is a major disadvantage when compared to other meats. Thus, Vieira et al., ${ }^{369}$ aiming to minimize microbial deterioration in chilled tambaqui fillets, studied the application of an edible chitosan coating and clove essential oil for the ability to reduce growth of pathogenic agents (Escherichia coli 0157: H7, Listeria monocytogenes, Salmonela enteritidis, Staphylococcus aureus and Pseudomonas aerugom). The results showed that the coating exerted an antimicrobial effect, proving more effective against $L$. monocytogenes and S. aureus, increasing the useful life of chilled tambaqui fillets and making this a potential alternative to improve the safety of aquaculture products and, consequently, expand the market.

Over the past 40 years, tambaqui products have been studied progressively, characterized for chemical composition, quality, conservation and diversification of derived products. The challenges for building relevant and systematic knowledge about tambaqui processing are many. ${ }^{370}$ Therefore, further investigation is needed on: (i) best pre-slaughter management and slaughter methods, which will be pivotal to obtaining highest-quality meat and derived products; (ii) standardization of tambaqui cuts, which is strategic to attract consumer fidelity; (iii) development of loin deboning techniques or even generating intermuscular bone-free loin strain by selective breeding (see the Genetics, genomics and selective breeding section) to add value to this favoured cut; (iv) developing packaging systems for advancing microbial food safety and longer shelf life; and (v) continuous assessment of the consumer market and preferences to support development of new products. Tambaqui has the potential to become an international fish commodity due to its excellent culture performance and its potential for the production of various processed by-products, suggesting following of the marketing path adopted by the poultry industry.

\section{CONCLUDING REMARKS}

South American aquaculture is dominated by production of nonnative species. However, the native tambaqui has the potential to make an even more significant contribution to regional aquaculture production. Most production has taken place in extensive or semiintensive systems, and can be intensified by more widespread adoption of intensive pond systems and use of cages in reservoirs. While induced spawning protocols have been developed, larviculture systems can be improved to grow the supply of high-quality seed stocks. Methods for production of all-female monosex stocks would be valued by farmers. Because this is a newly domesticated fish with a large geographic range, tambaqui presumably harbours considerable quantitative genetic variation for valued traits, including growth 
rate, morphometric traits, and parasite and disease resistance. Yet, quantitative genetic and molecular tools have not been systematically applied to breeding, an omission that we regard as worthy of further and sustained investment. Applied nutrition studies will contribute to the development of high-quality and cost-effective aquafeeds. Improved health management will decrease losses, especially as production intensifies. Improved processing and storage techniques will better maintain product quality through the marketing chain. Development of new value-added tambaqui products will create new market opportunities.

While targeted advancements are needed in these scientific and technical areas, considerable effort must be allocated to effective technical outreach and aquaculture extension so that advancements will be more readily adopted by farmers. This critical task is incumbent upon regional agricultural universities and ministries of agriculture.

\section{ACKNOWLEDGEMENTS}

The authors wish to acknowledge all the financial supporters for their research as follows: Coordenação de Aperfeiçoamento de Pessoal de Nível Superior-Brasil (CAPES), Conselho Nacional de Desenvolvimento Científico e Tecnológico (CNPq), Fundação de Amparo à Pesquisa do Estado de São Paulo (FAPESP), Fundação de Amparo à Pesquisa do Estado de Minas Gerais (FAPEMIG), Fundação de Amparo à Pesquisa do Estado do Amazonas (FAPEAM) and U.S Department of Agriculture under the National institute for Food and Agriculture. AWSH (304662/2017-8), DTH (311559/2018-2), LST (312051/2018-2), RGM (305493/2019-1) are recipients of CNPq productivity scholarship.

\section{CONFLICT OF INTEREST}

The authors declare no competing or financial conflicts of interests.

\section{AUTHOR CONTRIBUTIONS}

This work was conceived by all authors in their respective areas of expertise. $\mathrm{EH}$ edited the review, and AWSH developed the infographics and organized the final version of the review.

\section{ETHICS APPROVAL}

Not applicable.

\section{PATIENT CONSENT}

Not applicable.

\section{PERMISSION TO REPRODUCE MATERIAL}

Applicable.

\section{CLINICAL TRIAL REGISTRATION}

Not applicable.

\section{DATA AVAILABILITY STATEMENT}

Not applicable.

\section{ORCID}

Alexandre Wagner Silva Hilsdorf (D) https://orcid. org/0000-0001-9565-8072

Eric Hallerman (D) https://orcid.org/0000-0002-5839-858X

Gustavo Moraes Ramos Valladão (D) https://orcid. org/0000-0002-3875-6247

Micheli Zaminhan-Hassemer (iD) https://orcid.

org/0000-0001-5879-9132

Diogo Teruo Hashimoto (D) https://orcid.org/0000-0002-8808-2498

Jony Koji Dairiki (D) https://orcid.org/0000-0002-1899-6657

Leonardo Susumu Takahashi (D) https://orcid.

org/0000-0002-5820-188X

Francielly Corrêa Albergaria (D) https://orcid.

org/0000-0001-5641-2889

Maria Emília de Sousa Gomes (D) https://orcid.

org/0000-0002-2338-2684

Rossana Luiza Leite Venturieri (D) https://orcid.

org/0000-0002-3050-8310

Renata Guimarães Moreira (D) https://orcid.

org/0000-0001-8139-1776

José Eurico Possebon Cyrino (D) https://orcid.

org/0000-0002-8942-0102

\section{REFERENCES}

1. Araújo-Lima C, Goulding M. So fruitful a fish. Ecology, conservation, and aquaculture of the Amazon's tambaqui. New York, USA: Columbia University Press; 1997.

2. Goulding M. The fish and the forest: Exploration in Amazonian Natural History. California, USA: University of California Press; 1980.

3. Goulding M, Carvalho ML. Life history and management of the tambaqui (Colossoma macropomum, Characidae): an important Amazonian food fish. Rev Bras Zool. 1982;1(2):107-133. doi:10.1590/S0101-81751982000200001

4. Cagauan AG. Red-bellied pacu in the Philippines. J Environ Sci Manag. 2007;10(1):42-47.

5. Froese R \& Pauly D eds. FishBase. World Wide Web electronic publication. 2019; Accessed September 30, 2020. www.fishbase. org, version. (12/2019).

6. GBIF (Global Biodiversity Information Facility). Colossoma macropomum (Cuvier, 1816) GBIF Backbone Taxonomy. Checklist dataset, 2019.

7. FAO (Food and Agriculture Organization of the United Nations). Colossoma macropomum introduced to Thailand from Hong Kong, Singapore. Introduced Species Fact Sheets. 2020; Accessed September 6, 2020. http://www.fao.org/fishery/introsp/3885/ en

8. Nico $L \&$ Neilson $M$ Colossoma macropomum (Cuvier, 1816): Nonindigenous Aquatic Species Database, U.S. Geological Survey, Gainesville, FL, 2020. Accessed October 30, 2020. https://nas. er.usgs.gov/queries/FactSheet.aspx?SpeciesID $=418$

9. Honda SEM. Contribuição ao conhecimento da biologia de peixes do Amazonas. II. Alimentação de tambaqui, Colossoma bidens (Spix). Acta Amaz. 1974;4:47-53.

10. Araújo-Lima CARM, Ruffino ML. Migratory fishes of the Brazilian Amazon. In: Joachim C, Brian H, Carmen R, Baer A, eds. Migratory Fishes of South America: Biology, Fisheries and Conservation Status. World Fisheries Trust/World Bank/IDRC; 2004:233-306. 
11. Lucas CM. Within flood season variation in fruit consumption and seed dispersal by two characin fishes of the Amazon. Biotropica. 2008;40:581-589. doi:10.1111/j.1744-7429.2008.00415.x

12. Verissimo J. A Pesca na Amazônia. Livraria Clássica de Alves; 1895.

13. Lopes GCDS, Catarino MF, Lima ÁCD, Freitas CEDC. Small-scale fisheries in the Amazon basin: general patterns and diversity of fish landings in five sub-basins. B Inst Pesca. 2016;42:889-900. doi:10.20950/1678-2305.2016v42n4p889

14. Ihering RV. A method for inducing fish to spawn. Progress Fish Cult. 1937;4(34):15-16.

15. Hernández A, Muñoz-Lara D, Feraz de Lima J, et al. Estado actual del cultivo de Colossoma y Piaractus en Brasil, Colombia, Panamá, Perú, y Venezuela. Bol Red Acuic. 1992;6:3-28.

16. Silva JWB, Gurgel JJS. Situação do cultivo de Colossoma no âmbito do Departamento Nacional de Obras Contra as Secas (DNOCS). In: Hernández A, ed. Cultivo do Colossoma. Guadalupe, Ltda. 1989:229-258.

17. Guimarães SF. Alguns aspectos da aquicultura interior na região Norte de Brasil com ênfase na criação de tambaqui (Colossoma macropomum) e pirapitinga (Piaractus brachypomus): Situação atual e perspectivas. In: Souza, RHS, ed. Criação de Piaractus e Colossoma no Brasil, II Reunião do Grupo de Trabalho de Colossoma e Piaractus. Brazil: IBAMA; 1999:63-105.

18. Silva JWB, Figueiredo JJCB. Situação da criação de Colossoma e Piaractus no Nordeste Brasileiro: Janeiro de 1988 a Junho 1991. In: Souza, RHS, ed. Criação de Piaractus e Colossoma no Brasil, II. Reunião do Grupo de Trabalho de Colossoma e Piaractus. IBAMA; 1999:108-148.

19. Saint-Paul U. The neotropical serrasalmid Colossoma macropomum, a promising species for fish culture in Amazonia. Anim Res Dev. 1985;22:7-35.

20. Saint-Paul U. Potential for aquaculture of South American freshwater fishes: a review. Aquaculture. 1986;54:205-240.

21. Hernández RA. Cultivo de Colossoma (The Farming of Colossoma). Red Regional de Entidades y Centros de Acuicultura de America Latina; 1989.

22. Campos-Baca LE, Kohler CC. Aquaculture of Colossoma macropomum and related species in Latin America. Am Fish Soc Symp. 2005;46:541-561.

23. IBGE (Instituto Brasileiro de Geografia e Estatística). Produção Pecuária Municipal. 2020; Accessed November 09, 2020. https:// sidra.IBGE..gov.br/tabela/3940

24. FAO (Food and Agriculture Organization of the United Nations). Fisheries Global Information System (FIGIS). Fisheries Division, FAO. 2020.

25. Flores-Nava A, Brown A. Peces nativos de água dulce de América del Sur de interés para la acuicultura: Una síntesis del estado de desarrollo tecnológico de su cultivo. Serie Acuicultura en Latinoamérica. , 1st edn. FAO. 2010.

26. Valladão GMR, Gallani SU, Ikefuti CV, Da Cruz C, Levy-Pereira N, Rodrigues MVN. Essential oils to control ichthyophthiriasis in pacu, Piaractus mesopotamicus (Holmberg): Special emphasis on treatment with Melaleuca alternifolia. J Fish Dis. 2016;39(10):11431152. doi:10.1111/jfd.12447

27. Woynárovich A, Van Anrooy R. Field guide to the culture of tambaqui (Colossoma macropomum, Cuvier, 1816). FAO Fisheries and Aquaculture Technical Paper 624. FAO; 2019:1-121.

28. Val AL, de Oliveira AM. Colossoma macropomum-A tropical fish model for biology and aquaculture. J Exp Zool A Ecol Integr Physiol. 2021;335(9-10):761-770. doi:10.1002/jez.2536

29. Lovshin LL. Progress report on fisheries development in Northeast Brazil. Research and Development Series No. 9. International Center for Aquaculture, Agricultural Experiment Extension, Auburn University, AL, USA. April, 1975.

30. Lovshin LL, Silva AB, Fernandez JA, Carneiro-Sobrinho A. Preliminary pond culture test of pirapitinga Colossoma bidens, and tambaqui Colossoma macropomum, from the Amazon River basin. FAO Informes De Pesca. 1974;1(159):185-193.

31. Lovshin LL. Situación del cultivo de Colossoma sp. en Sud America. Rev Latinoam Acuicult. 1980;5:27-32.

32. Honda SEM, Correa CM, Castelo FP, Zapelini EA. Aspectos gerais do pescado no Amazonas. Acta Amaz. 1975;5(1):87-94. doi:10.1590/1809-43921975051087

33. Werder U, Saint-Paul U. Feeding trials with herbivorous and omnivorous Amazonian fishes. Aquaculture. 1978;15:175-177. doi:10. 1016/0044-8486(78)90062-5

34. Werder U, Saint-Paul U. Experiências de alimentação com tambaqui (Colossoma macropomum), pacu (Mylossoma sp), jaraqui (Semaprochilodus theraponura) e matrinchã (Brycon melanopterus). Acta Amaz. 1979;9(3):617-619. doi:10.1590/1809-43921979093617

35. Merola N, Souza JH. Preliminary studies on the culture of the pacu, Colossoma mitrei, in floating cages: effect of stocking density and feeding rate on growth performance. Aquaculture. 1988;68:243248. doi:10.1016/0044-8486(88)90356-0

36. Melo LAS, Izel ACU, Rodrigues FM. Criação de tambaqui (Colossoma macropomum) em viveiros de argila/barragens no Estado do Amazonas. Empresa Brasileira de Pesquisa Agropecuária (EMBRAPA), Documentos 18. EMBRAPA Amazônia Ocidental, Manaus, AM. 2001.

37. Izel ACU, Melo LAS. Criação de tambaqui (Colossoma macropomum) em tanques escavados no Estado do Amazonas. Empresa Brasileira de Pesquisa Agropecuária (EMBRAPA):2004.32.th. ed. EMBRAPA Amazônia Ocidental, Manaus, AM (Infoteca-E); 2004.

38. Inoue LAKA, Bezerra AC, Miranda WS, Muniz AW, Boijink CL. Cultivo de tambaqui em gaiolas de baixo volume: efeito da densidade de estocagem na produção de biomassa. Cien Anim Bras. 2014;15(4):437-443. doi:10.1590/1089-6891v15i426758

39. Morais IS, O'Sullivan FLA. Biologia, habitat e cultivo do tambaqui Colossoma macropomum (Cuvier, 1816). Sci Amazon. 2017;6(1):81-93.

40. Castelo FP, Amaya DR, Strong FC III. Aproveitamento e características da gordura cavitária do tambaqui, Colossoma macropomum Cuvier 1818. Acta Amazon. 1980;10(3):557-576. doi:10.1590/1809-43921980103557

41. Ferrari VA, Lucas AFB. Gaspar LA (1991) Desempenho do tambaqui Colossoma macropomum Cuvier, 1818, em monocultura experimental sob condições de viveiro-estufa e viveiro convencional ( $1^{\text {a }}$ fase) e em viveiro convencional ( $2^{\text {a }}$ fase) no Sudeste do Brasil. Bol Téc CEPTA. 1991;4(2):23-37.

42. Lovshin LL. The Colossomids. In: Nash CE, Novotny AL, eds. World Animal Science: Production of Aquatic Animals: Fishes. Elsevier Science; 1995:153-159.

43. Peralta M, Teichert-Coddington DR. Comparative production of Colossoma macropomum and Tilapia nilotica in Panama. J World Aquac. 1989;20(4):236-239. doi:10.1111/j.1749-7345.1989.tb010 08.x

44. Teichert-Coddington DR. Effects of stocking ratio on semiintensive polyculture of Colossoma macropomum and Oreochromis niloticus in Honduras. Central Am Aquac. 1996;143:291-302.

45. Liao IC, Su HM, Chang EY. Techniques in finfish larviculture in Taiwan. Aquaculture. 2001;200:1-31. doi:10.1016/S0044 $-8486(01) 00692-5$

46. Hancz C. Performance of the Amazonian tambaqui, Colossoma macropomum, in pond polyculture. Aquac Eng. 1993;12:245-254. doi:10.1016/0144-8609(93)90015-4

47. Sá MFP, Barbieri G, Verani JR. Análise do comportamento de Cyprinus carpio, Prochilodus cearensis e Colossoma macropomum em experimento de policultivo, embasado nos fatores de condição. Bol Inst Pesca. 2000;26(2):181-188.

48. Tafur-Gonzales J, Alcántara-Bocanegra F, Del Águila-Pizarro M, Cubas-Guerra R, Mori-Pinedo L, Chuu-Koo F. Paco Piaractus brachypomus y gamitana Colossoma macropomum criados en 
policultivo con el bujurqui-tucunaré, Chaetobranchus semifasciatus (Cichlidae). Folia Amazónica. 2009;18(1-2):97-104. doi:10.24841/ fa.v18i1-2.336

49. EMATER-AM (Empresa de Assistência Técnica e Extensão Rural do Estado do Amazonas). Sistema de Produção para a Criação do Tambaqui no Amazonas. EMATER-AM, Manaus, AM, Brazil. 1992.

50. Chellapa S, Chellappa NT, Barbosa WB, Huntingford FA, Beveridge MCM. Growth and production of the Amazonian tambaqui in fixed cages under different feeding regimes. Aquac Int. 1995;3:11-21. doi:10.1007/BF00240917

51. Cavalcanti RM. Verificação das potencialidades do camarão de água doce Macrobrachium jelskii (Miers, 1877) com o cultivo em viveiros de tambaqui Colossoma macropomum no município de Alto Alegre no Estado de Roraima. Rev Eletrônica Ambient. 2014;6:4553. doi:10.24979/222

52. Flickinger DL, Costa GA, Dantas DP, Moraes-Valenti P, Valenti WC. The budget of nitrogen in the grow-out of the Amazon river prawn (Macrobrachium amazonicum Heller) and tambaqui (Colossoma macropomum Cuvier) farmed in monoculture and in integrated multitrophic systems. Aquac Res. 2019;50(11):3444-3461.

53. Flickinger DL, Dantas DP, Proença DC, David FS, Valent WC. Phosphorus in the culture of the Amazon river prawn (Macrobrachium amazonicum) and tambaqui (Colossoma macropomum) farmed in monoculture and in integrated multitrophic systems. J World Aquac Soc. 2019;51(4):1002-1023. doi:10.1111/ jwas.12655

54. Flickinger DL, Costa GA, Dantas DP, et al. The budget of carbon in the farming of the Amazon river prawn and tambaqui fish in earthen pond monoculture and integrated multitrophic systems. Aquac Rep. 2020;17:1000340. doi:10.1016/j.aqrep.2020.100340

55. Franchini AC, Costa GA, Pereira AS, Valenti WC, Moraes-Valenti P. Improving production and diet assimilation in fish-prawn integrated aquaculture, using iliophagus species. Aquaculture. 2020;521:735048. doi:10.1016/j.aquaculture.2020.735048

56. Dantas DP, Flickinger DL, Costa GA, Batlouni SR, Moraes-Valenti $P$, Valenti WC. Technical feasibility of integrating Amazon river prawn culture during the first phase of tambaqui grow-out in stagnant ponds, using nutrient-rich water. Aquaculture. 2020;516:734611. doi:10.1016/j.aquaculture.2019.734611

57. Merola N, Pagán-Fon FA. Pond culture of the Amazon fish tambaqui, Colossoma macropomum: A pilot study. Aquac Eng. 1988;7:113125. doi:10.1016/0144-8609(88)90009-X

58. Superintendência da Zona Franca de Manaus (SUFRAMA). Projeto Potencialidades Regionais Estudo De Viabilidade Econômica: Piscicultura. SUFRAMA, Manaus, AM. 2003.

59. Sipaúba-Tavares LH, Braga FMS. The feeding activity of Colossoma macropomum larvae (tambaqui) in fishponds with water hyacinth (Eichhornia crassipes) fertilizer. Braz J Biol. 2007;67(3):459-466. doi:10.1590/S1519-69842007000300010

60. Gomes LC, Silva CR. Impact of pond management on tambaqui, Colossoma macropomum (Cuvier), production during growth-out phase. Aquac Res. 2009;40:825-832. doi:10.1111/ j.1365-2109.2009.02170.x

61. Souza ASL, Souza RAL, Peret AC, Melo NFAC, Rodrigues Filho JLR. Effect of organic and chemical fertilizers on the growth rate of tambaqui fish (Colossoma macropomum) (Pisces; Characidae) in floodplain fish ponds in the eastern Amazon, Pará State, Brazil. Bol Téc Cient CEPNOR. 2014;13(1):55-62. doi:10.1111/j.1365-2109.2009.02170.x

62. Izel ACU, Crescêncio R, O'Sullivan FALA, Chagas EC, Boijink $\mathrm{CL}$, Silva Jl. Produção intensiva de tambaqui em tanques escavados com aeração. Empresa Brasileira de Pesquisa Agropecuária (EMBRAPA)2013, Circular Técnica 39th edi. EMBRAPA Amazônia Ocidental, Manaus, AM; 2013.

63. Campos-Baca LEE. Cultivo de la gamitana en Latinoamérica. Instituto de Investigaciones de la Amazonía Peruana (IIAP) y
Universidad Nacional de la Amazonía Peruana (UNAP), Iquitos, Perú. 2015.

64. Castro AL, Souza NH, Barros LCG. Avaliação do sistema de produção de tambaqui intensivo em viveiro de terra com aeração. Empresa Brasileira de Pesquisa Agropecuária (EMBRAPA):2002. Comunicado Técnico 09th edi. EMBRAPA Tabuleiros Costeiros, Aracajú, SE; 2002.

65. Sousa RGC, Rocha MM, Pontuschka RB, Barbosa HTR. Effects of mechanical aeration on tambaqui farming (Colossoma macropomum) in excavated tanks. Acta Fish Aquat Res. 2017;5(3):122-128. doi:10.2312/ActaFish.2017.5.3.122-128

66. Beveridge MCM. Cage and pen fish farming: Carrying capacity models and environmental impact. FAO Fisheries Technical Paper.FAO; 1984:255-259.

67. Beveridge MCM. Cage Aquaculture, 3rd edn. Blackwell Publishing Ltd.; 2004.

68. Merola N, Souza JH. Cage culture of the Amazon fish tambaqui, Colossoma macropomum, at two stocking densities. Aquaculture. 1988;71:15-21. doi:10.1016/0044-8486(88)90269-4

69. Brandão FR, Gomes LC, Chagas EC, Araujo LD. Densidade de estocagem de juvenis de tambaqui durante a recria em tanquesrede. Pesq Agropec Bras. 2004;39(4):357-362. doi:10.1590/S0100 -204X2004000400009.

70. Gomes LC, Brandão FR, Chagas EC, Ferreira MFB, Lourenço JNP. Efeito do volume do tanque-rede na produtividade de tambaqui (Colossoma macropomum) durante a recria. Acta Amaz. 2004;34(1):111-113. doi:10.1590/S0044-59672004000100014

71. Silva CA. Boas práticas de manejo na criação de tambaquis em tanques-rede. Empresa Brasileira de Pesquisa Agropecuária (EMBRAPA):2015. Circular Técnica 77th edit. EMBRAPA Tabuleiros Costeiros, Aracajú, SE. 2015.

72. Arbeláez-Rojas GA, Fracalossi DM, Fim JDI. Composição corporal de tambaqui, Colossoma macropomum, e matrinxã, Brycon cephalus, em sistemas de cultivo intensivo, em igarapé, e semi-intensivo, em viveiros. Rev Bras Zootec. 2002;31(3):1059-1069. doi:10.1590/ S1516-35982002000500001

73. Poleo G, Aranbarrio JV, Mendoza L, Romero O. Cultivo de cachama blanca en altas densidades y en dos sistemas cerrados. Pesq Agropec Bras. 2011;46(4):429-437. doi:10.1590/S0100-204X2 011000400013

74. Silva ALB, Chagas EC, Gomes LC, Arapulo LD, Silva CR, Brandão FR. Toxicity and sublethal effects of potassium permanganate in tambaqui (Colossoma macropomum). J World Aquac Soc. 2013;37(3):318-321. doi:10.1111/j.1749-7345.2006.00043.x

75. Barroncas MF, Pereira-Filho M, Gomes LC, Roubach R, Ono EA. Efeitos da troca de água sobre os índices zootécnicos e qualidade dos efluentes na criação intensiva do tambaqui (Colossoma macropomum) em viveiros escavados. Rev Bras Eng Pesca. 2015;8(1):49-71.

76. Sousa RGC, Freitas HCP, Oliveira CM, Lima SAO, Mereles MA, Freitas CEC. Meat of Tambaqui from fish farming leads the popular preference when compared to wild specimens (RondôniaBrasil). Braz J Dev. 2020;6(3):11736-11753. doi:10.34117/bjdv6 n3-148

77. Silva WS, Ferreira AL, Neves LC, et al. Effects of stocking density on survival, growth and stress resistance of juvenile tambaqui (Colossoma macropomum) reared in a recirculating aquaculture system (RAS). Aquac Int. 2021;29:609-621. doi:10.1007/s10499-02100647-z

78. Arbelaéz-Rojas GA, Fracalossi DM, Fim JDI. Composição corporal de tambaqui, Colossoma macropomum, e matrinxã, Brycon cephalus, em sistemas de cultivo intensivo, em igarapé, e semi-intensivo, em viveiros. Rev Bras Zootec. 2002;31(3):1059-1069. doi:10.1590/ S1516-35982002000500001

79. Belchior EB, Dalchiavon FC. Economic viability of tambaqui production in the municipality of Ariquemes-RO. Bol Inst Pesca. 2017;43(3):373-384. doi:10.20950/1678-2305.2017v43n3p373 
80. Costa J, Freitas R, Gomes AL, Bernardino G, Carneiro DJ, Martins MI. Effect of stocking density on economic performance for Colossoma macropomum (Cuvier, 1816), juveniles in earthen ponds. Lat Am J Aquat Res. 2016;44(1):165-170. doi:10.3856/vol44-issue 1-fulltext-18

81. Gomes LC, Chagas EC, Martins-Júnior H, Roubach R, Ono EA, Lourenço JNP. Cage culture of tambaqui (Colossoma macropomum) in a central Amazon floodplain lake. Aquaculture. 2006;253(1-4):374-384. doi:10.1016/j.aquaculture.2005.08.020

82. Craveiro J, Salvatierra M, Silva Neto G, Tribuzy K, Freitas C. A system to optimize fish production: a case study of semi-intensive Colossoma macropomum (Osteichthyes, Serrasalmidae) aquaculture. Lat Am J Aquat Res. 2019;47(3):492-501. doi:10.3856/vol47 -issue3-fulltext-11

83. Botelho HA, Leira MH, Melo CCV, Café MB, Freitas RTF. Determinação da curva de crescimento e alometria de pacu (Piaractus mesopotamicus), tambaqui (Colossoma macropomum) e seus híbridos. Agrarian. 2019;12(43):97-103.

84. Lima CAS, Machado-Bussons MRF, Pantoja-Lima J. Classificação dos sistemas de produção e grau de impacto ambiental das pisciculturas no estado do Amazonas, Brasil. Rev ColombCienc Anim. 2019;11(1):14p. doi:10.24188/recia.v11.n1.2019.707

85. Pedroza Filho MX, Matos FT, Moro GV, Lima AF. Desafios da intensificação produtiva de tambaqui em sistemas de tanque-rede. Bol Ativos Aquic. 2017;12:1-7.

86. Gomes LC, Araújo-Lima CARM, Roubach R, Chippari-Gones AR, Lopes NP, Urbinati EC. Effect of fish density during transportation on stress and mortality of juvenile tambaqui Colossoma macropomum. J World Aquac Soc. 2003;34(1):76-84. doi:10.1111/ j.1749-7345.2003.tb00041.x

87. Ismiño-Orbe RA, Araújo-Lima CARM, Gomes LC. Excreção de amônia por tambaqui (Colossoma macropomum) de acordo com variações na temperatura da água e massa do peixe. Pesa Agropec Bras. 2003;38(10):1243-1247. doi:10.1590/S0100-204X200300 1000015

88. Costa OTF, Ferreira DJS, Mendonça FLP, Fernandes MN Susceptibility of the Amazonian fish, Colossoma macropomum (Serrasalminae), to short-term exposure to nitrite. Aquaculture. 2004;232(1-4), 627-636. doi:10.1016/S0044-8486(03)00524-6

89. Penna MAH, Villacorta-Correa MA, Walter T, Petrere-Junior M. Growth of the tambaqui Colossoma macropomum (Cuvier) (Characiformes: Characidae): which is the best model? Braz J Biol. 2005;65(1):129-139.

90. Jimezez-Montealegre R, Avnimelech Y, Verreth JAJ, Verdegem MC. Nitrogen budget and fluxes in Colossoma macropomum ponds. Aquac Res. 2005;36(1):8-15. doi:10.1111/j.1365-2109.2004.01174.x

91. Aride PHR, Roubach R, Nozawa SR, Val AL. Val AL Tambaqui growth and survival when exposed to different photoperiods. Acta Amaz. 2006;36(3):381-384. doi:10.1590/S0044-5967200600 0300015

92. Silva ADR, Santos RB, Bruno AMSS, Soares EC. Cultivo de tambaqui em canais de abastecimento sob diferentes densidades de peixes. Acta Amaz. 2006;43(4):517-524.

93. Centeno L, Silva-Acuña R, Barrios R, Luco RS, Matute C, Pérez JL. Características hematológicas de la cachama (Colossoma macropomum) en tres etapas de crecimiento cultivadas en el estado Delta Amacuro, Venezuela. Zootecnia Trop. 2007;25(4):237-243.

94. Aride PHR, Roubach R, Val AL. Tolerance response of tambaqui Colossoma macropomum (Cuvier) to water pH. Aquac Res. 2007;38:588-594. doi:10.1111/j.1365-2109.2007.01693.x

95. Mendonça OO, Vidal Júnior MV, Polese MF, Santos MVB, Rezende FP, Andrade DR. Morphometrical development of tambaqui (Colossoma macropomum, Cuvier, 1818) under different photoperiods. Rev Bras Zootec. 2012;41(6):1337-1341.

96. Fiúza LS, Aragão NM, Ribeiro Júnior HP, et al. Effects of salinity on the growth, survival, haematological parameters and osmoregulation of tambaqui Colossoma macropomum juveniles. Aquac Res. 2015;46(Suppl 1):1-9. doi:10.1111/are.12224

97. Souza-Bastos LR, Bastos LP, Carneiro PCF, Freire CA. Acute salt exposure of the freshwater Characiformes: pacu (Piaractus mesopotamicus, Holmberg 1887), tambaqui (Colossoma macropomum, Cuvier 1818), and their hybrid "tambacu". Aquaculture. 2016;465:352-358. doi:10.1016/j.aquaculture.2016.09.028

98. Sylvain FE, Cheaib B, Llewellyn M, et al. pH drop impacts differentially skin and gut microbiota of the Amazonian fish tambaqui (Colossoma macropomum). Sci Rep. 2016;6(1):32032. doi:10.1038/ srep32032

99. Paz AL, Val AL. Manipulation of growth of the Amazonian fish tambaqui, Colossoma macropomum (Characiformes: Serrasalmidae): Analysis of physiological and zootechnical aspects. Acta Amaz. 2018;48(3):197-206. doi:10.1590/1809-4392201800181

100. Mesquita RCT, Galvão JA, Savbay-da-Silva LK, Eloy LR, Godoy LC, Streit DP Jr. Protocol for tambaqui production based on stocking density and sex. Rev Bras Hig Sanid Anim. 2018;12(2):146-155. doi: 10.5935/1981-2965.20180014

101. Fernandes EM, de Almeida LCF, Hashimoto DT, et al. Survival of purebred and hybrid Serrasalmidae under low water temperature conditions. Aquaculture. 2018;497:97-102. doi:10.1016/j.aquac ulture.2018.07.030

102. Wood CM, Gonzalez RJ, Ferreira MS, Braz-Mota S, Val AL. The physiology of the tambaqui (Colossoma macropomum) at $\mathrm{pH}$ 8.0. J Comp Physiol B. 2018;188:393-408. doi:10.1007/s0036 0-017-1137-y

103. Mourad MMN, Costa AC, Freitas RTF, Serafini MA, Reis Neto RV, Felizardo VO. Weight and morphometric growth of pacu (Piaractus mesopotamicus) tambaqui (Colossoma macropomum) and their hybrids from spring to winter. Pesq Vet Bras. 2018;38(3):544-550. doi:10.1590/1678-5150-PVB-4808

104. Ruiz-Jarabo I, Amanajás RD, Baldisserotto B, Mancera JM, Val AL. Tambaqui (Colossoma macropomum) acclimated to different tropical waters from the Amazon basin shows specific acutestress responses. Comp Biochem Physiol Part A Mol Integr Physiol. 2020;245:110706. doi:10.1016/j.cbpa.2020.110706

105. Vieira EF, Isaac VJ, Fabré NN. Biologia reprodutiva do tambaqui Colossoma macropomum Cuvier, 1818 (Teleostei Serrasalmideo) no Baixo Amazonas Brasil. Acta Amaz. 1999;29(4):625-638.

106. Barthem RB, Fabré NN. Biologia e diversidade dos recursos pesqueiros da Amazônia. In: A pesca e os recursos pesqueiros na Amazônia brasileira/Coordenado por Mauro Luis Ruffino. IBAMA/ ProVárzea. 2004;17-51.

107. Araújo-Lima C, Gomes L. Tambaqui Colossoma macropomum. In: Baldisseroto B, Gomes L, eds. Espécies Nativas para Piscicultura no Brasil. Editora UFSM; 2005:175-214.

108. Santos GM, dos Santos GM, Ferreira EJG, Zaunon JAS. Peixes comerciais de Manaus, 2nd edn. IBAMA/AM, ProVárzea. 2006.

109. Da Silva A, Carneiro A, Melo F. Contribuição ao estudo sobre o uso da hipófise da curimata común Prochilodus ceaerensis na reprodução artificial do tambaqui Colossoma macropomum, Cuvier 1818. Editor Centro de Pesquisas Ictiologias Rodolpho Von Ihering, Departamento Nacional de Obras Contra as Secas (DNOCS), Fortaleza, Brazil, 1976.

110. Woynarovich E. Propagação artificial e criação de alevinos de tambaqui Colossoma macropomum. CODEVASF; 1986.

111. Woynárovich A, Woynárovich E. Reproduccion artificial de las especies Colossoma y Piaractus - Una guia detallada para la produccion de alevinos de gamitana, paco y caraña, Editorial Taller. Publicación del FONDEPES. Lima, Peru. 1998.

112. Eufracio Villón P, Palomino Ramos A. Manual de Cultivo de Gamitana:2004. Fondo Nacional de Desarrollo Pesquero (FONDEPES); 2004.

113. Streit DP Jr, Povh JA, Fornari DC, et al. técnicas para a reprodução do tambaqui:2012, 1st edn. EMBRAPA Meio-Norte; 2012. 
114. Souza JSL, Almeida FL. Desenvolvimento gonadal de tambaqui Colossoma macropomum. Anais da IX Jornada de Iniciação Cientifica da Embrapa Amazônia Ocidental - Manaus, 100 - 320, 2012.

115. Almeida FL, Lopes JS, Crescencio R, Izel ACU, Chagas EC Boijink C. Early puberty of farmed tambaqui (Colossoma macropomum): Possible influence of male sexual maturation on harvest weight. Aquaculture. 2016;452:224-232. doi:10.1016/j.aquac ulture.2015.10.031

116. Woynarovich E. Manual de piscicultura:1993. Traduzido por Melo MJ. Brasília: CODEVASF, IL. CDU 639.311. 1993.

117. Zaniboni FE, Barbosa NDC. Priming hormone administration to induce spawning of some Brazilian migratory fish. Rev Bras Biol. 1996;56:655-659.

118. Alix M, Olav SK, Anderson KC. From gametogenesis to spawning: How climate-driven warming affects teleost reproductive biology. J Fish Biol. 2020;97(3):607-632. doi:10.1111/jfb.14439

119. Servili A, Canario AVM, Mouchel O, Muñoz-Cueto JA. Climate change impacts on fish reproduction are mediated at multiple levels of the brain-pituitary-gonad axis. Gen Comp Endocrinol. 2020;291:113439. doi:10.1016/j.ygcen.2020.113439

120. Trudeau VL, Somoza GM. Multimodal hypothalamo-hypophysial communication in the vertebrates. Gen Comp Endocrinol. 2020;293:113475. doi:10.1016/j.ygcen.2020.113475

121. Lubzens E, Young G, Bobe J, Cerdà J. Oogenesis in teleosts: How fish eggs are formed. Gen Comp Endocrinol. 2010;165:367-389. doi:10.1016/j.ygcen.2009.05.022

122. Mylonas CC, Fostier A, Zanuy S. Broodstock management and hormonal manipulations of fish reproduction. Gen Comp Endocrinol. 2010;165(3):516-534. doi:10.1016/j.ygcen.2009.03.007

123. Woynárovich E, Horváth L. Propagação artificial de peixes de águas tropicais, Brasília:1983. FAO/CODEVASF/CNPq. 1983.

124. Chellappa S, Cacho MSRF, Huntingford FA, Beveridge M. Observations on induced breeding of the Amazonian fish tambaqui, Colossoma macropomum (Cuvier) using CPE and HCG treatments. Aquac Res. 1996;27(2):91-94. doi:10.1111/j.1365-2109.1996.tb00971.x

125. Acuña JJA, Rangel JLH. Efectos del extracto hipofisiario de carpa común y el análogo de la GNRH sobre la maduración final de oocito y el desove de la cachama negra (Colossoma macropomum). Rev Cient. 2009;19(5):486-494.

126. Souza FN, Martins EDFF, Corrêa Filho RAC, et al. Ovopel ${ }^{\circledR}$ and carp pituitary extract for induction of reproduction in Colossoma macropomum females. Anim Reprod Sci. 2018;195:53-57. doi:10.1016/j. anireprosci.2018.05.005

127. Garcia RRF, Vasconcelos ACN, Povh JA, et al. Functional integrity of Colossoma macropomum (Cuvier, 1816) sperm cryopreserved with enriched extender solutions. Neotrop Ichthyol 2015;13(3):599606. doi:10.1590/1982-0224-20140142

128. Alcantara-Bocanegra F, Guerra-Flores H. Avances en la produccion de alevinos de gamitana, Colossoma macropomum y paco, C. brachypomum por reproduccion inducida. Folia Amazón. 1988;1(1-2):1-12

129. Santos AM, Sousa RGC. Monitoramento do desempenho reprodutivo do tambaqui cultivado em Presidente Médici (Rondônia). Sci Amazon. 2015;4(3):13-20

130. Leite LV, Melo M, Oliveira F, et al. Determinação da dose inseminante e embriogênese na fertilização artificial de tambaqui (Colossoma macropomum). Arq Bras Med Vet Zootec. 2013;65(2):421429. doi:10.1590/S0102-09352013000200018

131. Castro JS, Braz-Mota S, Campos DF, Souza SS, AI V. High temperature, $\mathrm{pH}$ and hypoxia cause oxidative stress and impair the spermatic performance of the Amazon fish Colossoma macropomum. Front Physiol. 2020;11:772. doi:10.3389/fphys.2020.00772

132. Maria AN, Azevedo HC, Santos JP, Carneiro PCF. Hormonal induction and semen characteristics of tambaqui Colossoma macropomum. Zygote. 2011;20(1):39-43. doi:10.1017/S0967199410000559
133. Santos SS, Lopes JP, Santos-Neto MA, Santos LS. Larvicultura do tambaqui em diferentes densidades de estocagem. Rev Bras Eng Pesca. 2007;2(3):18-25.

134. SENAR (Serviço Nacional de Aprendizagem Rural). Piscicultura: Reprodução, larvicultura e alevinagem de peixes nativos. SENAR; 2017.

135. Sevignani D, Buzzacaro E, Fortuna NB. Monitoramento da hora-grau necessária para extrusão de ovócitos de reprodutoras de Colossoma macropomum. Sci Electron Arch. 2020;3:57-63. doi:10.36560/1362020946

136. Morais RM, Souto NC, Silva LAS, Pádua DMC. Concentração espermática e fertilização artificial de ovócitos do híbrido tambacu (Colossoma macropomum x Piaractus mesopotamicus). Sci Agrar Parana. 2018;17(1):144-148.

137. Galo J, Ribeiro R, Streit D Jr, et al. Oocyte quality of tambaqui (Colossoma macropomum) during the reproductive season. Braz J Biol. 2015;75(2):279-284. doi:10.1590/1519-6984.10113

138. Konzen-Freitas AR, Abreu JG, Abreu JS, Dantas VLQ, Corrêa Filho RAC, Povh JÁ. Tambaqui females (Colossoma macropomum) spawn after hormonal induction with buserelin acetate. Anim Reprod Sci. 2020;22:106594. doi:10.1016/j.anireprosci.2020.106594

139. Pessoa NO, Evangelista JSAM, de Sousa Filho FGM, de Sousa MLNM, Lourenço AV, Sampaio CMS. Resfriamento de embriões de tambaqui (Colossoma macropomum) em diferentes tempos de estocagem. Revi Bras Hig Sanid Anim. 2013;7(2):323-344.

140. Almeida CAL, Vieira JS, Zancanela VT, et al. Desenvolvimento embrionário e o efeito de diferentes dietas no desempenho de póslarvas de tambaqui. Interciencia. 2019;44(11):637-643.

141. Vieira M, Carvalho M, Salmito-Vanderley C, et al. Características do sêmen de tambaqui (Colossoma macropomum) em latitude equatorial. Arch De Zootec. 2011;60(232):1263-1270.

142. Gregorin EG, Felizardo VO, Melo CCV, Freitas RTF, Souza UN, Costa AC. Parâmetros qualitativos do sêmen e morfologia comparada da cabeça e peça intermediária do espermatozoide de pirapitinga (Piaractus brachypomus), pacu (Piaractus mesopotamicus) e tambaqui (Colossoma macropomum). Bol Ind Anim. 2019;76:1-8. doi:10.17523/bia.2019.v76.e1437

143. Maria AN, Azevedo HC, Santos JP, Silva CA, Carneiro PCF. Semen characterization and sperm structure of the Amazon tambaqui Colossoma macropomum. J Appl Ichthyol. 2010;26(5):779-783. doi:10.1111/j.1439-0426.2010.01542.x

144. Carneiro PCF, Azevedo HC, Santos JP, Maria AN. Cryopreservation of tambaqui (Colossoma macropomum) semen: extenders, cryoprotectants, dilution ratios and freezing methods. CryoLetters. 2012;33(5):385-393.

145. Varela Junior AS, Corcini CD, Gheller SMM, et al. Use of amides as cryoprotectants in extenders for frozen sperm of tambaqui, Colossoma macropomum. Theriogenology. 2012;78:244-251. doi:10.1016/j.theriogenology.2012.02.029

146. Maria AN, Carvalho ACM, Araújo RV, Santos JP, Carneiro PCF Azevedo HC. Use of cryotubes for the cryopreservation of tambaqui fish sêmen (Colossoma macropomum). Cryobiology. 2015;70:109-114. doi:10.1016/j.cryobiol.2015.02.004

147. Pastrana YM, Streit DP Jr, Garcia RRF, Becker BS, Rodrigues JL, Godoy L. A fructose-based extender protects Colossoma macropomum spermatozoa against chilling injuries. Aquac Res. 2018;50(2):521-528. doi:10.1111/are.13923

148. Maria AN, Azevedo HC, Carneiro PCF. Protocolo para criopreservação do sêmen de tambaqui (Colossoma macropomum):2011. Comunicado Técnico 112th edi. EMBRAPA, 2011.

149. Pinheiro JPS, Leite-Castro LV, Oliveira FDCED, Linhares FRA, Lopes JT, Salmito-Vanderley CSB. Qualidade do sêmen de tambaqui (Colossoma macropomum) criopreservado em diferentes concentrações de gema de ovo. Ciênc Anim Bras. 2016;17(2):267-273. doi:10.1590/1089-6891v17i225386 
150. Pires LB, Corrêa Filho RAC, Sanches EA, et al. Colossoma macropomum females can reproduce more than once in the same reproductive period. Anim Reprod Sci. 2018;196:138-142. doi:10.1016/j. anireprosci.2018.07.006

151. Sato LS, Jorge PH, Mastrochirico-Filho VA, et al. Triploidy in tambaqui Colossoma macropomum identified by chromosomes of fish larvae. J Aquac Mar Biol. 2020;9(3):65-69.

152. Galo JM, Streit DP Jr, Corcini CD, Varela AS Jr, Jardim RD, Ribeiro RP. Protein profile as a quality indicator of cryopreserved semen from tambaqui Colossoma macropomum (Cuvier, 1818). Braz J Biol. 2020;80(4):752-762. doi:10.1590/1519-6984.219140

153. Bobe J, Labbé C. Egg and sperm quality in fish. Gen Comp Endocrinol. 2010;165(3):535-548.

154. Pedreira MM, Schorer M, Ferreira AL. Utilização de diferentes dietas na primeira alimentação de larvas de tambaqui. Rev Bras Saúde Prod Anim. 2015;16(2):440-448. doi:10.1590/S1519-9940201500 0200018

155. Johnston IA, Vieira VL. Larval development in the tambaqui (Colossoma macropomum) and curimatã-pacu (Prochilodus marggravii). Fish Physiol Biochem. 1996;43-55.

156. Pedreira MM, Sipaúba-Tavares LH. Effect of light green and dark brown colored tanks on survival rates and development of tambaqui larvae, Colossoma macropomum (Osteichthyes, Serrasalmidae). Acta Sci. 2001;23(2):521-525.

157. Tavares-Dias M, Araújo CSO, Porto SMA, Viana GM, Monteiro PC Sanidade do tambaqui Colossoma macropomum nas fases de larvicultura e alevinagem: 2013. 78th ed. EMBRPA Amapá-Documentos (INFOTECA-E) 2013.

158. Jomori RK, Luz RK, Takata R, Fabregat TEHP, Portella MC. Água levemente salinizada aumenta a eficiência da larviculturade peixes neotropicais. Pesq Agrop Bras. 2013;48(8):809-815. doi:10.1590/ S0100-204X2013000800001

159. Morais IDSD, Reis VR, De Almeida FL. The influence of the water $\mathrm{pH}$ on the sex ratio of tambaqui colossoma macropomum (CUVIER, 1818). Aquac Rep. 2020;17:100334. doi:10.1016/j. aqrep.2020.100334

160. Campos EC, Oliveira CAL, Araújo FCT, et al. Genetic parameters and response to selection for growth in tambaqui. Animal. 2020;14(9):1777-1785. doi:10.1017/S1751731120000488

161. Sevilla A, Gunther J. Growth and feeding level in pre-weaning tambaqui Colossoma macropomum Larvae. J World Aquac Soc. 2007;31:218-224. doi:10.1111/j.1749-7345.2000.tb00356.x

162. Beux LF, Zaniboni-Filho E. Influência da baixa salinidade na sobrevivência de náuplios de Artemia sp. Bol Inst Pesca. 2006;32:73-77.

163. Santos FAC, Julio GSC, Luz RK. Stocking density in Colossoma macropomum larviculture, a freshwater fish, in recirculating aquaculture system. Aquac Res. 2021;52:1185-1191. doi:10.1111/ are.14976

164. Lima RLVA. Determinação de esteróides e eletrólitos plasmáticos em fêmeas adultas de tambaqui Colossoma macropomum (Cuvier, 1818) Pisces, Teleostei durante a maturação gonadal. Master of Science Thesis. Universidade de São Paulo, São Paulo; 1997.

165. Nakaghi LSO, Mitsuiki D, Santos HSL, Pacheco MR, Ganeco LN Morphometry and morphology of nucleus of the Sertoli and interstitial cells of the tambaqui Colossoma macropomum (Cuvier, 1881) (Pisces: Characidae) during the reproductive cycle. Braz J Biol. 2003;63(1):97-104. doi:10.1590/S1519-69842003000100013

166. Lobo IKC, Nascimento ÁR, Yamagishi MEB, et al. Transcriptome of tambaqui Colossoma macropomum during gonad differentiation: Different molecular signals leading to sex identity. Genomics. 2020;112:2478-2488. doi:10.1016/j.ygeno.2020.01.022

167. Vasconcelos ACN, Streit DP, Octavera A, et al. Isolation and characterization of a germ cell marker in teleost fish Colossoma macropomum. Gene. 2019;683:54-60. doi:10.1016/j.gene.2018.10.027

168. Menezes JTB, Queiroz LJD, Doria CRC, Menezes JB Jr. Avaliação espermática pós-descongelamento em tambaqui, Colossoma macropomum (Cuvier, 1818). Acta Amaz. 2008;38(2):365-368. doi:10.1590/S0044-59672008000200023

169. Leite LV, Oliveira F, Nunes LT, Nunes JF, Salmito-Vanderley CSB. Sperm cryopreservation of tambaqui in powdered coconut water (ACPTM) added of egg yolk. Rev Bras Eng Pesca. 2011;6:23-29. doi:10.18817/repesca.v6i2.421

170. Viveiros ATM, Moura AAAN, Nunes JF. Características do sêmen de tambaqui (Colossoma macropomum) em latitude equatorial Arch. Zootec. 2011;60(232):1263-1270. doi:10.4321/S0004-05922 011000400041

171. Carvalho MAM, Linhares FRA, Nunes JF, Salgueiro CCM, Costa RZ, Sales RO. Água de coco como diluente para o sêmen de peixes de água doce de fertilização externa. Rev Bras Hig Sanid Anim. 2014;8(4):203-222.

172. Melo-Maciel M, Leite-Castro L, Leite J, et al. Aloe vera in the cryopreservation of tambaqui (Colossoma macropomum) sperm. Arq Bras Med Vet Zootec. 2015;67(3):945-949. doi:10.1590/1678-4162-7807

173. Pires LB, Sanches EA, Romagosa E, et al. Sperm quality of Colossoma macropomum after room-temperature and cold storage. J Appl Ichthyol. 2019;35(3):747-753. doi:10.1111/jai.13864

174. Galo JM, Streit-Jr DP, Corcini CD, Varela-Jr JRD, Ribeiro RP. Protein profile as a quality indicator of cryopreserved semen from Tambaqui Colossoma macropomum (Cuvier, 1818). Braz J Biol. 2020;80(4):752-762. doi:10.1590/1519-6984.219140

175. Streit DP Jr, Fornari DC, Povh JAL, et al. Germplasm banking and its role in the development of the fish genetic improvement programme In Brazil. CryoLetters. 2015;36(6):399-404.

176. Viveiros ATM, Godinho HP. Sperm quality and cryopreservation of Brazilian freshwater fish species: a review. Fish Physiol Biochem. 2008;35(1):137-150. doi:10.1007/s10695-008-9240-3

177. Garcia RRF, Streit DP, Cabrita E, Godoy LC. Semen cryopreservation in Brazilian freshwater fish: Advances and main challenges. Cryopreservation in Eukaryotes. Tech Publishing; 2016:57-73.

178. Digmayer M. Influência da baixa temperatura e diferentes crioprotetores em oócitos e embriões de Colossoma macropomum e Piaractus brachypomus. Master of Science Thesis. Programa de PósGraduação em Zootecnia da Universidade Estadual de Maringá -Área de concentração Produção Animal; 2013.

179. Reis VR, Almeida FL. Effect of 17-oestradiol on the sex ratio of tambaqui, Colossoma macropomum. Aquac Res. 2019;50:154-161. doi:10.1111/are.13878

180. Tiwary BK, Kirubagaran R, Raym AK. The biology of triploid fish. Rev Fish Biol Fisheries. 2004;14(4):391-402. doi:10.1007/s1116 0-004-8361-8

181. Almeida-Toledo LF, Foresti F, Toledo-Filho SA, Bernardino G, Ferrari VA, Alcantara RCG. Cytogenetic studies in Colossoma mitrei, C. macropomum and their interspecific hybrid. In: Tiews K, ed. Selection, Hybridization and Genetic Engineering in Aquaculture. Heenemann Verlagsgesellschaft; 1987:189-195.

182. Almeida-Toledo LF, Foresti F, Ramos SM, Ormanezi R, Carolsfeld VJS, Toledo Filho AS. Estudos citogenéticos de híbridos entre fêmeas de pacu (Piaractus mesopotamicus) e machos de tambaqui (Colossoma macropomum). Bol Téc CEPTA. 1988;1:1-17.

183. Bernardino G, Mendonça JOJ, Ribeiro LP, Alcantara RCG, Ferrari VA, Fijan N. Primeira produção do tambacu. In: Síntese dos Trabalhos realizados com Espécies do gênero Colossoma (Projeto Aqüicultura/Brasil 3-7-76-0001 -CIID), CEPTA; 1986:11-12.

184. Silva JWB, Caminha MIO, Nobre MIS, Barros Filho FMB. Resultados de um ensaio sobre o cultivo do híbrido do tambaqui, Colossoma macropomum Cuvier, 1818, com a pirapitinga, C. brachypomum Cuvier, 1818, realizado no Centro de Pesquisas Ictiológicas "Rodolpho von Ihering" (Pentecoste, Ceará, Brasil). Ciênc Agron. 1986;2:7-18.

185. Pinheiro MHP, Silva JWB, Nobre MIS, Pinheiro FA. Cultivo do híbrido tambaqui, Colossoma macropomum Cuvier, 1818, com a 
pirapitinga, C. brachypomum Cuvier, 1818, na densidade de 5.000 peixes/ha. Ciênc. Agron. 1991;22(1/2):77-87.

186. Hashimoto DT, Senhorini JA, Foresti F, Porto-Foresti F. PortoForesti F (2012) Interspecific fish hybrids in Brazil: Management of genetic resources for sustainable use. Rev Aquac. 2012;4(2):108118. doi:10.1111/j.1753-5131.2012.01067.x

187. Ramirez-Mora JN, Useche MC, Niño PA, Leal C, Baldisserotto B. Production of cachama reciprocal hybrids in earth ponds. Ciênc Rural. 2019;49(11):e20180113. doi:10.1590/0103-8478cr20180113

188. Mair G, Lucente D. What are" farmed types" in aquaculture and why do they matter? FAO Aquac Newsl. 2020;61:40-42.

189. Calcagnotto D, Almeida-Toledo LF, Bernardino G, ToledoFilho SA. Biochemical genetic characterization of F1 reciprocal hybrids between neotropical pacu (Piaractus mesopotamicus) and tambaqui (Colossoma macropomum) reared in Brazil. Aquaculture. 1999;174(1-2):51-57. doi:10.1016/S0044-8486(99)00005-8

190. Santos VHD, Foresti F, Oliveira C, Almeida-Toledo LFD, ToledoFilho DAS. Bernardino G Synaptonemal complex analysis in the fish species Piaractus mesopotamicus and Colossoma macropomum, and in their interspecific hybrid. Caryologia. 2002;55(1):7379. doi:10.1080/00087114.2002.10589260

191. Nirchio M, Fenocchio AS, Swarça AC, et al. Cytogenetic characterization of hybrids offspring between Colossoma macropomum (Cuvier, 1818) and Piaractus brachypomus (Cuvier, 1817) from Caicara del Orinoco, Venezuela. Caryologia. 2003;56(4):405-411. doi:10.1080/00087114.2003.10589351

192. Ribeiro RP, Rodriguez-Rodriguez MP, Resende EK, et al. Genetic characteristics of tambaqui broodstocks in the state of Rondônia, Brazil: Implications on production and conservation, Semina. Ciênc Agrár. 2016;37(4Suppl1):2375-2386. doi:10.5433/1679-0359

193. Leitão MAB. Estudo comparativo da estrutura genética de populações naturais e artificiais de tambaqui Colossoma macropomum (Cuvier, 1818): sistemas isozímicos (Comparative study of the genetic structure of natural and artificial populations of tambaqui Colossoma macropomum (Cuvier, 1818): isozyme systems). Master of Science dissertation, INPA-FUA (National Institute of Amazonian Research), Manaus. 1998.

194. Santos CHDA, Leitão MAB, Sousa CFS, Santana GX, Paula-Silva MN, Almeida-Val VMF. Genetic variability of wild and captivity populations of Colossoma macropomum (Cuvier, 1818. Acta Sci Biol Sci. 2012;34(2):191-197. doi:10.4025/actascibiolsci.v34i2.7149

195. Schlötterer C. The evolution of molecular markers - just a matter or fashion? Nat Rev Genet. 2004;5(1):63-69.

196. Santos MDCF, Hrbek T, Farias IP. Microsatellite markers for the tambaqui (Colossoma macropomum, Serrasalmidae, Characiformes), an economically important keystone species of the Amazon River floodplain. Mol Eco Resour. 2009;9(3):874-876. doi:10.1111/j.1755-0998.2008.02331.x

197. Santana GX, Santos CHA, Sousa CFS, et al. Isolation of novel microsatellite markers for tambaqui (Colossoma macropomum, Cuvier 1818), an important freshwater fish of the Amazon. Conservation Genet Resour. 2012;4(1):197-200. doi:10.1007/s12686-011-9507-3

198. Hamoy IG, Santos S. Multiplex PCR panel of microsatellite markers for the tambaqui, Colossoma macropomum, developed as a tool for use in conservation and broodstock management. Genet Mol Res. 2012;11(1):141-146. doi:10.4238/2012.January.26.1

199. Ariede RB, Freitas MV, Hata ME, et al. Microsatellites associated with growth performance and analysis of resistance to Aeromonas hydrophila in tambaqui Colossoma macropomum. Front Genet. 2018:9:3. doi:10.3389/fgene.2018.00003

200. Farias IP, Torrico JP, García-Dávila C, Santos MDCF, Hrbek T, Renno $J F$. Are rapids a barrier for floodplain fishes of the Amazon basin? A demographic study of the keystone floodplain species Colossoma macropomum (Teleostei: Characiformes). Mol Phylogenet Evol. 2010;56(3):1129-1135. doi:10.1016/j.ympev.2010.03.028
201. Fazzi-Gomes P, Guerreiro S, Palheta GDA, Melo NFAD, Santos S, Hamoy I. High genetic diversity and connectivity in Colossoma macropomum in the Amazon basin revealed by microsatellite markers. Genet Mol Biol. 2017;40(1):142-146. doi:10.1590/1678-4685-GMB-2015-0222

202. Waples RS, Gaggiotti O. What is a population? An empirical evaluation of some genetic methods for identifying the number of gene pools and their degree of connectivity. Mol Ecol. 2006;15(6):14191439. doi:10.1111/j.1365-294X.2006.02890.x

203. Martínez JG, Machado VN, Caballero-Gaitán SJ, et al. SNPs markers for the heavily overfished tambaqui Colossoma macropomum, a Neotropical fish, using next-generation sequencing-based de novo genotyping. Conservation Genet Resour. 2017;9(1):29-33. doi:10.1007/s12686-016-0610-3

204. Hilsdorf AWS, Hallerman EM. Genetic Resources of Neotropical Fishes, 1st edn. Springer International Publishing; 2017.

205. Lopera-Barrero NM, Rodriguez-Rodriguez MP, Fornari DC et al. Genetic variability of broodstocks of tambaqui (TeleosteiCharacidae) from the northeast region of Brazil, Semina. Ciênc Agrár. 2015;36(6):4013-4021. doi:10.5433/1679-0359

206. De Queiroz CA, Sousa NR, da Silva GF, Inoue LAKA. Impacts of stocking on the genetic diversity of Colossoma macropomum in central Amazon, Brazil. In EMBRAPA Amazônia Ocidental - Resumo em anais de congresso (ALICE). Genet Mol Res. 2016;15(2):1-9.

207. Aguiar J, Schneider H, Gomes F, et al. Genetic variation in native and farmed populations of tambaqui (Colossoma macropomum) in the Brazilian Amazon: regional discrepancies in farming systems. An Acad Bras Ciênc. 2013;85(4):1439-1447.

208. Aguiar JDP, Gomes PFF, Hamoy IG, Santos SEBD, Schneider H, Sampaio I. Loss of genetic variability in the captive stocks of tambaqui, Colossoma macropomum (Cuvier, 1818), at breeding centres in Brazil, and their divergence from wild populations. Aquac Res. 2018;49(5):1914-1925. doi:10.1111/are.13647

209. Melo ER, Nascimento AíP, Corrêa STB, et al. Genetic characterization of tambaqui stocks from two pisciculture stations in the lower São Francisco River, Semina. Ciênc Agrár. 2020;41(6Supl2):3 323-3334. doi:10.5433/1679-0359

210. Oliveira CDST, Moreira RFC, Soares Filho AA, Fonteles SBA Evangelista-Barreto NS. Genetic diversity in natural populations of Colossoma macropomum in the Brazilian Amazon region and in populations farmed in Northeast Brazil based on ISSR markers. Aquacult Int. 2019;27(5):1423-1434. doi:10.1007/s10499-01900395-1

211. Santos CHA, Santana GX, Leitão CSS, Paula-Silva MN, AlmeidaVal VMF. Loss of genetic diversity in farmed populations of Colossoma macropomum estimated by microsatellites. Anim Genet. 2016;47(3):373-376. doi:10.1111/age.12422

212. Fazzi-Gomes PF, Melo NF, Palheta G, et al. Characterization of the genetic resources of farmed tambaqui in northern Brazil. J Agric Sci. 2017;9(10):76-84.

213. Neto AM, Ayres DR, Junior DPS, et al. Genetic diversity of tambaqui broodstocks in stock enhancement programs. Semina. Ciênc Agrár. 2017;38(3):1655-1659. doi:10.5433/1679-0359

214. Gonçalves RA, Santos CHDAD, Sá-Leitão CS, Souza ÉMS, AlmeidaVal VMF. Genetic basis of Colossoma macropomum broodstock: Perspectives for an improvement program. J World Aquac Soc. 2019;50(3):633-644. doi:10.1111/jwas.12564

215. Urrea-Rojas AM, Souza FP, Lima ECS, et al. Genetic diversity of tambaqui (Teleostei-Characidae) broodstocks from northern region of Brazil using microsatellite markers, Semina. Ciênc Agrár. 2020;41(6Suppl 2):3249-3258. doi:10.5433/1679-0359

216. Gómez-Agudelo JF. Estudos de variabilidade genética em lotes cultivados de tambaqui (Colossoma macropomum) na América do Sul (Studies of genetic variability in cultivated lots of tambaqui (Colossoma macropomum) in South America). Master of Science 
Dissertation, Centro de Aquicultura da Universidade Estadual Paulista, CAUNESP, Jaboticabal; 2020.

217. Mello FD, Oliveira CAL, Streit D Jr, et al. Estimation of genetic parameters for body weight and morphometric traits of tambaqui Colossoma macropomum. J Fish Sci. 2016;10(2):96-100.

218. Perazza CA, Ferraz JBS, Almeida-Val VMF, Hilsdorf AWS. Genetic parameters for loin eye area and other body traits of an important Neotropical aquaculture species, Colossoma macropomum (Cuvier, 1818). Aquac Res. 2019;50(10):2907-2916. doi:10.1111/are.14245

219. Marcos R, Ribeiro RP, Abreu JSD, et al. Growth curve of selectively bred and non-selectively bred tambaqui (Colossoma macropomum). An Acad Bras Ciênc. 2020;92(3). e20190099. doi:10.1590/0001-3765202020190099

220. Silva ACC, Barros AFD, Mendonça FMF, et al. Performance and economic viability of tambaqui, Colossoma macropomum, selectively bred for weight gain. Acta Amaz. 2020;50(2):108-114. doi:10.1590/1809-4392201901992

221. Resende EKD. Pesquisa em rede em aquicultura: bases tecnológicas para o desenvolvimento sustentável da aqüicultura no Brasil. Aquabrasil. Rev Bras Zootec. 2009;38:52-57.

222. Perazza CA, Menezes JTB, Ferraz JBS, Pinaffi FLV, Silva LA, Hilsdorf AWS. Lack of intermuscular bones in specimens of Colossoma macropomum: An unusual phenotype to be incorporated into genetic improvement programs. Aquaculture. 2020;472:5760. doi:10.1016/j.aquaculture.2016.05.014

223. Perazza CA, Pinaffi FLV, Silva LA, Hilsdorf AWS. Evaluation of ultrasound imaging to predict loin eye area in tambaqui. Bol Inst Pesca. 2015;41(Special):803-809.

224. Nunes JDRDS, Liu S, Pértille F, et al. Large-scale SNP discovery and construction of a high-density genetic map of Colossoma macropomum through genotyping-by-sequencing. Sci Rep. 2017;7:46112. doi:10.1038/srep46112

225. Varela ES, Bekaert M, Ganeco-Kirschnik LN, et al. A high-density linkage map and sex-linked markers for the Amazon Tambaqui Colossoma macropomum. BMC Genom. 2021;22:709. doi:10.1186/ s12864-021-08037-8

226. Nunes JRS, Pértille F, Andrade SCS, et al. Genome-wide association study reveals genes associated with the absence of intermuscular bones in tambaqui (Colossoma macropomum). Anim Genet. 2020;51(6):899-909. doi:10.1111/age.13001

227. Machado AM, Ferraz R, Ribeiro RA, Ozorio R, Castro LF. From the Amazon: a comprehensive liver transcriptome of the teleost tambaqui, Colossoma macropomum. Data in Brief. 2019;23:103751. doi:10.1016/j.dib.2019.103751

228. Ferraz RB, Machado AM, Navarro JC, et al. The fatty acid elongation genes elovl $4 a$ and elovl $4 b$ are present and functional in the genome of tambaqui (Colossoma macropomum). Comp Biochem Physiol B Biochem Mol Biol. 2020;245:110447. doi:10.1016/j. cbpb.2020.110447

229. Barbosa CM, Mareco EA, Silva MDP, Martins C, Alves-Costa FA. Differential expression of a retrotransposable element, Rex6, in Colossoma macropomum fish from different Amazonian environments. Mob Genet Elements. 2014;4(4):e30003. doi:10.4161/ mge. 30003

230. Gomes F, Watanabe L, Nozawa S, et al. Identification and characterization of the expression profile of the microRNAs in the Amazon species Colossoma macropomum by next generation sequencing. Genomics. 2017;109(2):67-74. doi:10.1016/j.ygeno.2017.02.001

231. Fé-Gonçalves LM, Araújo JDA, Santos CHDA, Val AL, Almeida-Va VMF. How will farmed populations of freshwater fish deal with the extreme climate scenario in 2100? Transcriptional responses of Colossoma macropomum from two Brazilian climate regions. Therm Biol. 2020;89:102487. doi:10.1016/j.jtherbio.2019.102487

232. Fé-Gonçalves LM, Araújo JDA, Santos CHDAD, AlmeidaVal VMFD. Transcriptomic evidences of local thermal adap tation for the native fish Colossoma macropomum (Cuvier,
1818). Genet Mol Biol. 2020;43(3):e20190377. doi:10.1590/ 1678-4685-GMB-2019-0377

233. Yáñez JM, Houston RD, Newman S. Genetics and genomics of disease resistance in salmonid species. Front Genet. 2014;5:415. doi:10.3389/fgene.2014.00415

234. Bishop SC, Woolliams JA. Genomics and disease resistance studies in livestock. Livest Sci. 2014;166:190-198. doi:10.1016/j. livsci.2014.04.034

235. Ariede RB, Freitas MV, Agudelo JFG, et al. Genetic (co)variation between resistance to Aeromonas hydrophila and growth in tambaqui (Colossoma macropomum). Aquaculture. 2020;523735225. doi:10.1016/j.aquaculture.2020.735225

236. Lira LV, Ariede RB, Freitas MV, et al. Quantitative genetic variation for resistance to the parasite Ichthyophthirius multifiliis in the Neotropical fish tambaqui (Colossoma macropomum). Aquac Rep. 2020;17:100338. doi:10.1016/j.aqrep.2020.100338

237. Gjedrem T, Rye M. Selection response in fish and shellfish: a review. Rev Aquac. 2018;10(1):168-179. doi:10.1111/raq.12154

238. Ødegård J, Baranski M, Gjerde B, Gjedrem T. Methodology for genetic evaluation of disease resistance in aquaculture species: challenges and future prospects. Aquac Res. 2011;42:103-114. doi:10.1111/j.1365-2109.2010.02669.x

239. Falconer DS, Mackay TFC. Introduction to Quantitative Genetics, 4th edn. Longman; 1996.

240. You X, Shan X, Shi Q. Research advances in the genomics and applications for molecular breeding of aquaculture animals. Aquaculture. 2020;526:735357. doi:10.1016/j.aquaculture.2020.735357

241. Houston RD. Future directions in breeding for disease resistance in aquaculture species. Rev Bras Zootec. 2017;46(6):545-551. doi:10.1590/S1806-92902017000600010

242. Van Dijk EL, Jaszczyszyn Y, Naquin D, Thermes C. The third revolution in sequencing technology. Trends Genet. 2018;34(9):666681. doi:10.1016/j.tig.2018.05.008

243. Hinaux H, Poulain J, Da Silva C, et al. De novo sequencing of Astyanax mexicanus surface fish and Pachón cavefish transcriptomes reveals enrichment of mutations in cavefish putative eye genes. PLoS One. 2013;8(1):e53553. doi:10.1371/journ al.pone.0053553

244. Vialle RA, Souza JEF, Lopes KP, et al. Whole genome sequencing of the pirarucu (Arapaima gigas) supports independent emergence of major teleost clades. Genome Biol Evol. 2018;10(9):2366-2379. doi:10.1093/gbe/evy130

245. Du K, Wuertz S, Adolfi M, et al. The genome of the arapaima (Arapaima gigas) provides insights into gigantism, fast growth and chromosomal sex determination system. Sci Rep. 2019;9:5293. doi:10.1038/s41598-019-41457-x

246. Schartl M, Kneitz S, Volkoff $\mathrm{H}$, et al. The piranha genome provides molecular insight associated to its unique feeding behavior. Genome Biol Evol. 2019;11(8):2099-2106. doi:10.1093/gbe/evz139

247. Hilsdorf AWS, Uliano-Silva M, Coutinho LL, Montenegro $\mathrm{H}$, Almeida-Val VMF, Pinhal D. Genome assembly and annotation of the tambaqui (Colossoma macropomum): an emblematic fish of the Amazon River Basin. Gigabyte. 2020;1:1-14. doi:10.46471/gigab yte.29

248. Mastrochirico-Filho VA, Ariede RB, Freitas MV, et al. Development of a multi-species SNP array for serrasalmid fish Colossoma macropomum and Piaractus mesopotamicus. Sci Rep. 2021;11:19289. doi:10.1038/s41598-021-98885-x

249. Houston RD, Bean TP, Macqueen DJ, et al. Harnessing genomics to fast-track genetic improvement in aquaculture. Nat Rev Genet. 2020;21(7):389-409. doi:10.1038/s41576-020-0227-y

250. Almeida-Val VMF, Val AL. A adaptação de peixes aos ambientes de criação. In: Val AL, Honczaryc A, eds. Criando peixes na Amzônia. INPA; 1995:45-49.

251. Silva JAM. Nutrientes, energia e digestibilidade aparente de frutos e sementes consumidos pelo tambaqui (Colossoma macropomum 
Cuvier, 1818) nas florestas inundáveis da Amazônia Central. Master of Science Thesis. Programa de Pós-graduação em Biologia Tropical e Recursos Naturais do INPA/UFAM. Manaus/AM; 1996.

252. Silva JAM, Pereira-Filho M, de Oliveira-Pereira MI. Seasonal variation of nutrients and energy in tambaqui's (Colossoma macropomum Cuvier, 1818) natural food. Rev Bras Biol. 2000;60(4):599-605. doi:10.1590/S0034-71082000000400009

253. Dairiki JK, Silva TBA. Revisão de literatura: exigências nutricionais do tambaqui - compilação de trabalhos, formulação de ração adequada e desafios futuros:2011. 91th ed. Manaus, EMBRAPA Amazônia Ocidental, Documento 2011.

254. Wilson RP. Amino acids and proteins. In: Halver JE, ed. Fish Nutrition, 3rd edn. Academic Press; 2002.

255. NRC (National Research Council). Nutrient Requirements of Fish and Shrimp. National Academy Press; 2011.

256. Macedo EM, Castagnolli N, Cyrino JEP. Nível proteico ideal na nutrição do tambaqui Colossoma macropomum Cuvier (Pisces, Characidae). In: Santos WJ, Arruda BKG, Dutra-de-Oliveira JE, Lopes N, Sayeg D, Tosello A Campos J Jr, editors. Proceedings of the 11th International Congress of Nutrition, Abstracts and Free Contributions, 1st edn. International Congress of Nutrition XI. 1978:307.

257. Macedo EM. Necessidades Proteicas na Alimentação do Tambaqui (Colossoma macropomum Cuvier, 1818 Pisces Characidae). Master of Science Thesis. Universidade Estadual Paulista Júlio de Mesquita Filho (UNESP), Campus de Jaboticabal, SP, Brasil; 1979.

258. Macedo-Viegas EM, Castagnolli N, Carneiro DJ. Níveis de proteína bruta em dietas para o crescimento do tambaqui Colossoma macropomum, Cuvier, 1818 (Pisces Characidae). Rev Unimar. 1996;18:321-333.

259. Merola N, Cantelmo OA. Growth, feed conversion and mortality of cage reared tambaqui, Colossoma macropomum, fed various dietary feeding regimes and protein levels. Aquaculture. 1987;66:223-233.

260. Van Der Meer MB, Machiels MAM, Verdegem MCJ. The effect of dietary protein level on growth, protein utilization and body composition of Colossoma macropomum (Cuvier). Aquac Res. 1995;26:901-909.

261. Vidal Junior MV, Donzele JL, Da Silva Camargo AC, De Andrade DR, Dos Santos LC. Níveis de proteína bruta para tambaqui (Colossoma macropomum), na fase de 30 a 250 gramas. 1. Desempenho dos tambaquis. (Levels of Crude Protein for Tambaqui (Colossoma macropomum), in the Phase of 30 to 250 grams 1. The Tambaquis Performance). Rev Bras Zootec. 1998;27:421-426.

262. Gutiérrez FW, Quispe M, Valenzuela L, Contreras G, Zaldívar J. Utilización de la proteína dietaría por alevinos de la gamitana, Colossoma macropomum, alimentados con dietas isocalóricas. Rev Peru Biol. 2010;17(2):219-223.

263. Santos L, Filho PM, Sobreira C, Ituassús D, Da Fonseca FA. Exigência protéica de juvenis de tambaqui (Colossoma macropomum) após privação alimentar. Acta Amaz. 2010;40(3):597-604.

264. Lima CS, Bonfim MAD, De Siqueira JC, Ribeiro FB, Lanna EAT Crude protein levels in the diets of tambaqui, Colossoma macropomum (cuvier, 1818), fingerlings. Rev Caatinga. 2016;29(1):183-190. doi:10.1590/1983-21252016v29n121rc

265. Oishi C, Nwanna LC, Pereira FM. Optimum dietary protein requirement for Amazonian tambaqui, Colossoma macropomum Cuvier, 1818, fed fish meal free diets. Acta Amaz. 2010;40(4):757776. doi:10.1590/S0044-59672010000400017

266. Vieira JLM. Níveis de proteína bruta no desempenho de juvenis de tambaqui criados em tanques-rede durante a fase de recria. Nutritime. 2017;14(2):5038-5045.

267. Amancio ALDL, Silva MRD, Jordão J, Fonseca SBD, Silva JHVD. Dietary protein requirements for tambaqui Colossoma macropomum (Cuvier, 1818) juvenile. Rev Ciênc Agron. 1818;2019(50):259266. doi:10.5935/1806-6690.20190030

268. Buzollo H, Sandre LCG, Neira LM, Nascimento TMT, Jomori RK, Carneiro DJ. Digestible protein requirements and muscle growth in juvenile tambaqui (Colossoma macropomum). Aquac Nutr. 2019;25:669-679. doi:10.1111/anu.12888

269. Abimorad EG, Carneiro DJ. Digestibility and performance of pacu (Piaractus mesopotamicus) juveniles fed diets containing different protein, lipid, and carbohydrate levels. Aquac Nutr. 2007;13(1):1-9. doi:10.1111/j.1365-2095.2007.00438.x

270. Gatlin DM, Barrows FT, Brown P, et al. Expanding the utilization of sustainable plant products in aquafeeds: a review. Aquac Res. 2007;38(6):551-579. doi:10.1111/j.1365-2109.2007.01704.x

271. Rodrigues APO. Nutrição e alimentação do tambaqui (Colossoma macropomum). Bol Inst Pesca. 2014;40(1):135-145.

272. Tave D. Genetics for Fish Hatchery Managers. AVI Publishing Co.; 1986.

273. Ogino C. Requirements of carp and rainbow trout for essential amino acids. Bull Jpn Soc Sci Fish. 1980;46:171-174.

274. Lima CS, Bomfim MAD, De Siqueira JC, Lanna EAT, Ribeiro FB, Firmo DS. Crude protein reduction with amino acid supplementation in tambaqui fingerling diets. Semina Ciênc Agrár. 2015;36(6):4531-4540. doi:10.5433/1679-0359

275. Marchão RS, Ribeiro FB, De Siqueira JC, et al. Digestible lysine requirement for tambaqui (Colossoma macropomum) juveniles using the diet dilution technique. Aquac Rep. 2020;18:100482. doi:10.1016/j.aqrep.2020.100482

276. Bonfim MAD, Marchão RS, Ribeiro FB, Siqueira JC, Silva LR, Takishita SS. Digestible tryptophan requirement for tambaqui (Colossoma macropomum) fingerlings. Rev Cien Agron. 2020;51(2):e20196724. doi:10.5935/1806-6690.20200025

277. Pezzato LE, Barros MM, Fracalossi DM, Cyrino JEP. Nutrição de peixes. In: Cyrino JEP, Urbinati EC, Fracalossi DM, Castagnolli $\mathrm{N}$, eds. Tópicos Especiais em Piscicultura de Agua Doce Tropical Intensiva. TecArt; 2004:75-169.

278. Lopes PRS, Pouey JLOF, Enke DBS, Martins CR, Timm G. Desempenho de alevinos de jundiá Rhamdia quelen alimentados com diferentes níveis de energia na dieta. Biodivers Pampeana. 2006:4:32-37.

279. Mommsen TP, Walsh PJ. Biochemical and environmental perspectives on nitrogen metabolism in fishes. Experientia. 1992:48:583-593.

280. Wood CM. Ammonia and urea metabolism and excretion. In: Evans DH, ed. Physiology of Fishes. CRC Press; 1993:379-425.

281. Guimarães IG, Martins GP. Nutritional requirement of two Amazonian aquacultured fish species, Colossoma macropomum (Cuvier, 1816) and Piaractus brachypomus (Cuvier, 1818): a mini review. J Appl Ichthyol. 2015;31:57-66. doi:10.1111/jai.12976

282. Camargo ACS, Júnior MVV, Donzele JL, de Andrade DR, dos Santos LC. Níveis de energia metabolizável para tambaqui (Colossoma macropomum) dos 30 aos 180 gramas de peso vivo. 1. Composição das carcaças. $R$ Bras Zootec. 1998;27(3):409-415.

283. Oliveira ACB, Miranda EC, Correa R. Exigências nutricionais e alimentação do tambaqui. In: Fracalossi DM, Cyrino JEP, eds. Nutriaqua: nutrição e alimentação de espécies de interesse para a aquicultura brasileira. Sociedade Brasileira de Aquicultura e Biologia Aquática; 2012:231-240.

284. Paulino RR, Pereira RT, Fontes TV, et al. Optimal dietary linoleic acid to linolenic acid ratio improved fatty acid profile of the juvenile tambaqui (Colossoma macropomum). Aquaculture. 2018;488:916. doi:10.1016/j.aquaculture.2018.01.014

285. Ferraz RB, Kabeya N, Lopes-Marques M, et al. A complete enzymatic capacity for long-chain polyunsaturated fatty acid biosynthesis is present in the Amazonian teleost tambaqui, Colossoma macropomum. Comp Biochem Physiol B Biochem Mol Biol. 2019;227:90-97. doi:10.1016/j.cbpb.2018.09.003

286. Watanabe Wade O, Ellis SC, Chaves J. Effects of dietary lipid and energy to protein ratio on growth and feed utilization of juvenile mutton snapper Lutjanus analis fed isonitrogenous diets 
at two temperatures. J World Aquacult Soc. 2007;32(1):30-40 doi:10.1111/j.1749-7345.2001.tb00919.x

287. De Almeida LC, Avilez IM, Honorato CA, Hori TSF, Moraes G. Growth and metabolic responses of tambaqui (Colossoma macropomum) fed different levels of protein and lipid. Aquac Nutr. 2011;17(2):253-262. doi:10.1111/j.1365-2095.2010.00759.x

288. Sandre LCG, Buzollo H, Nascimento TMT, Neira LM, Jomori RK, Carneiro DJ. Productive performance and digestibility in the initial growth phase of tambaqui (Colossoma macropomum) fed diets with different carbohydrate and lipid levels. Aquac Rep. 2017;6:28-34. doi:10.1016/j.aqrep.2017.02.003

289. Pezzato LE, Miranda EC, Barros MM, Pinto LGQ, Furuya WM Pezzato AC. Digestibilidade aparente de ingredientes pela tilápia do Nilo (Oreochromis niloticus). Rev Bras Zootec. 2002;31(4):15951604. doi:10.1590/S1516-35982002000700001

290. Abimorad EG, Carneiro DJ. Métodos de coleta de fezes e determinação dos coeficientes de digestibilidade da fração protéica e da energia de alimentos para o pacu Piaractus mesopotamicus (Holmberg, 1887). Rev Bras Zootec. 2004;33(5):1101-1109. doi:10.1590/S1516-35982004000500001

291. Buzollo H, Sandre LCG, Neira LM, Jomori RK, Carneiro DJ. Apparent digestibility coefficients of feedstuff used in tambaqui diets. Bol Inst Pesca. 2018;44:1-7.

292. Nascimento TMT, Buzollo H, Sandre LCG, Neira LM, Abimorad EG, Carneiro DJ. Apparent digestibility coefficients for amino acids of feed ingredients in tambaqui (Colossoma macropomum) diets. Rev Bras Zootec. 2020;49:20190032. doi:10.37496/rbz4920190032

293. Baker EM. Vitamin C requirements in stress. Am J Clin Nutr. 1967;20(6):583-590.

294. Chagas EC, Val AL. Efeito da vitamina $C$ no ganho de peso e em parâmetros hematológicos de tambaqui. Pesqu Agropecu Bras. 2003;38(3):397-402.

295. Aride PHR, Ferreira MS, Duarte RM, et al. Ascorbic acid (Vitamin C) and iron concentration in tambaqui, Colossoma macropomum, iron absorption. J World Aquac Soc. 2010;41(s2):291-297.

296. Sousa TJR. Exigência de fósforo para tambaqui (Colossoma macropomum) em diferentes faixas de peso. Master of Science Dissertation. Centro de ciências Agrárias e Ambientais Programa de PósGraduação em Ciência Animal. Universidade Federal do Maranhão; 2017.

297. Silva RS, Santo RVE, Barbosa AVC, et al. Digestibilidade aparente do farelo de palmiste em tambaqui (Colossoma macropomum). Ara Bras Med Vet Zootec. 2019;71(5):1595-1600. doi:10.1590/1678-4162-10968

298. Silva AF, Copattia CE, Oliveira EP, et al. Effects of whole banana meal inclusion as replacement for corn meal on digestibility, growth performance, haematological and biochemical variables in practical diets for tambaqui juveniles (Colossoma macropomum). Aquac Rep. 2020;17:100307. doi:10.1016/j.aqrep.2020.100307

299. Bicudo AJ, Araujo TA, Braga LG, Tonini WC, Hisano H. Apparent digestibility of conventional and alternative feedstuffs by hybrid tambacu juveniles. An Acad Bras Ciênc. 2018;90:471-478.

300. Campeche DFB, Melo JFB, Balzana L, Souza RC, Figueiredo RACR. Farelo de licuri em dietas para alevinos de tambaqui (Colossoma macropomum Cuvier 1818). Ara Bras Med Vet Zootec. 2014;66(2):539-545. doi:10.1590/1678-41625920

301. Aride PHR, Oliveira AT, Ferreira MS, Baptista RB, Santos SM, Pantoja-Lima J. Growth and hematological responses of tambaqui fed different amounts of cassava (Manihot esculenta). Arq Bras Med Vet. 2016;68(6):1697-1704. doi:10.1590/1678-4162-8704

302. Mori-Pinedo LA, Pereira M, Oliveira-Pereira MID. Substituição do fubá de milho (Zea mays, L.) por farinha de pupunha (Bactris gasipaes, HBK) em rações para alevinos de tambaqui (Colossoma macropomum, Cuvier 1818). Acta Amaz. 1999;29:447.

303. Lopes JM, Pascoal LAF, Silva Filho FP, et al. Farelo de babaçu em dietas para tambaqui. Rev Bras Saúde Prod Anim. 2010;11:519-526.
304. Pereira Junior G, Pereira Filho M, Roubach R, Barbosa PS, Farinha $\mathrm{SE}$. de folha de leucena (Leucaena leucocephala Lam. de wit) como fonte de proteína para juvenis de tambaqui (Colossoma macropomum Cuvier. Acta Amaz. 1818;2013(43):227-234. doi:10.1590/ S0044-59672013000200014

305. Dairiki JK, Correa RB, Inoue LAKA, Morais IDSD. Feijão-caupi autoclavado na nutrição de juvenis de tambaqui. Pesq Agropec Bras. 2013;48:450-453.

306. Valenti WC, Barros HP, Moraes-Valenti P, Bueno GW, Cavalli RO. Aquaculture in Brazil: past, present and future. Aquac Rep. 2021;19:100611. doi:10.1016/j.aqrep.2021.100611

307. Golvan YJ, d'Amazonie A. Redescription d' Oligacanthorhynchus iheringi Travassos 1916 et description de Neoechinorhynchus buttnerae n. sp. (Neoacanthocephala-Neoechinorhynchidae). Ann Parasitol Hum Comp. 1956;31(5-6):500-524.

308. Kritsky DC, Thatcher VE, Kayton RJ. Neotropical Monogenoidea. 2. The Anacanthorinae price, 1967, with the proposal of four new species of Anacanthorus Mizelle \& Price, 1965 from Amazonian fishes. Acta Amaz. 1979;9(2):355-361.

309. Thatcher VE, Paredes V. A parasitic copepod, Perulernaea gamitanae gen. et $s p$. nov. (Cyclopoida: Lernaeidae), from the nasal fossae of a Peruvian Amazon food fish. Amazoniana. 1985;9(2): 169-175.

310. Valladão GMR, Gallani SU, Jerônimo GT, Seixas AT. Challenges in the control of acanthocephalosis in aquaculture: special emphasis on Neoechinorhynchus buttnerae. Rev Aquac. 2019;12(3):13601372. doi:10.1111/raq.12386

311. Castro LDA, Jerônimo GT, Silva RMD, Santos MJ, Ramos CA, Porto SMDA. Occurrence, pathogenicity, and control of acanthocephalosis caused by Neoechinorhynchus buttnerae: a review. Rev Bras Parasitol Vet. 2020;29(3):e008320. doi:10.1590/S1984-29612 020070

312. Lourenço FS, Morey GAM, de Malta JCO. The development of Neoechinorhynchus buttnerae (Eoacanthocephala: Neoechinorhynchidae) in its intermediate host Cypridopsis vidua in Brazil. Acta Parasit. 2018;63(2):354-359. doi:10.1515/ ap-2018-0040

313. Silva-Gomes AL, Coelho-Filhho JG, Viana-Silva W, Braga-Oliveira MI, Bernardino G, Costa Jl. The impact of Neoechinorhynchus buttnerae (Golvan, 1956) (Eoacanthocephala: Neochinorhynchidae) outbreaks on productive and economic performance of the tambaqui Colossoma macropomum (Cuvier, 1818), reared in ponds. Lat Am J Aquat Res. 2017;45(2):496-500. doi:10.3856/vol45-issue2fulltext-25

314. Jerônimo GT, Pádua SBD, Belo MADA, et al. Neoechinorhynchus buttnerae (Acanthocephala) infection in farmed Colossoma macropomum: A pathological approach. Aquaculture. 2017;469:124-127. doi:10.1016/j.aquaculture.2016.11.027

315. Lopes NP, da Conceição Gomes AG, Farias RC, Caldas MAC, Lopes G. Efeito do extrato pirolenhoso de Cinnamomum zeylanicum e Mimosa caesalpiniifolia sobre o parasita Neoechinorhynchus buttnerae. Braz J of Dev. 2020;6(4):20798-20808. doi:10.34117/bjdv6 n4-306

316. Seixas AT, Gallani SU, Fernandes IM, Fernandes IEC, Jerônimo GT, Pilarski F. Effect of nutraceuticals on acanthocephalan Neoechinorhynchus buttnerae and its toxicity to the host tambaqui Colossoma macropomum. J Helminthol. 2020;94:E102. doi:10.1017/ S0022149X19000956

317. Seixas AT, Gallani SU, Noronha LDS, et al. Copaifera oleoresins as a novel natural product against acanthocephalan in aquaculture: Insights in the mode of action and toxicity. Aquac Res. 2020;51:4681-4688. doi:10.1111/are.14813

318. Sebastião FDA, Braga de Oliveira MI, Rocha MJS, et al. Effect of a food additive in the control of the acanthocephalan Neoechinorhynchus buttnerae in Colossoma macropomum. Aquac Res. 2020;52(2):635-642. doi:10.1111/are.14920 
319. Costa CMDS, da Cruz MG, Lima TBC, et al. Efficacy of the essential oils of Mentha piperita, Lippia alba and Zingiber officinale to control the acanthocephalan Neoechinorhynchus buttnerae in Colossoma macropomum. Aquac Rep. 2020;18:100414. doi:10.1016/j. aqrep.2020.100414

320. Wei JZ, Li H, Yu H. Ichthyophthiriasis: Emphases on the epizootiology. Lett Appl Microbiol. 2013;57(2):91-101. doi:10.1111/ lam.12079

321. Martins ML, Cardoso L, Marchiori N, Benites de Pádua S. Protozoan infections in farmed fish from Brazil: diagnosis and pathogenesis. Rev Bras Parasitol Vet. 2015;24(1):1-20. doi:10.1590/S1984-29612015013

322. Von Gersdorff JL. The fish parasite Ichthyophthirius multifiliis host immunology, vaccines and novel treatments. Fish Shellfish Immunol. 2017;67:586-595. doi:10.1016/j.fsi.2017.06.044

323. Fischer C, Malta JCDO, Varella AMB. A fauna de parasitas do tambaqui, Colossoma macropomum (Cuvier, 1818) (Characiformes: Characidae) do médio rio Solimões, estado do Amazonas (AM) e do baixo rio Amazonas, estado do Pará (PA), e seu potencial como indicadores biológicos. Acta Amaz. 2003;33(4):651-662. doi:10.1590/S0044-59672003000400012

324. Cohen SC, Kohn A. On Dactylogyridae (Monogenea) of four species of characid fishes from Brazil. Check List. 2009;5(2):351-356. doi:10.15560/5.2.351

325. Santos EF, Tavares-Dias M, Pinheiro DA, Neves LR, Marinho RGB, Dias MKR. Fauna parasitária de tambaqui Colossoma macropomum (Characidae) cultivado em tanque-rede no estado do Amapá, Amazônia oriental. Acta Amaz. 2013;43(1):105-111.

326. Alcántara-Bocanegra F, Verdi-Olivares L, Murrieta-Morey G, Rodríguez-Chu L, Chu-Koo F. Águila-Pizarro M Parásitos de alevinos de gamitana (Colossoma macropomum) y pacu (Piaractus brachypomus) cultivados en el C.I. Quistococha, Loreto, Perú. Cienc Amazón. 2015;5(1):42-49. doi:10.22386/ca.v5i1.89

327. Vargas LM, Sandoval CN, Casas AE, Pizango PG, Manchego AS. Parásitos y lesiones histopatológicas en branquias de gamitanas (Colossoma macropomum) juveniles bajo crianza semiintensiva. Rev Investig Vet Perú. 2015;26(4):577-586. doi:10.15381/rivep. v26i4.11222

328. Rocha MJS, Jerônimo GT, Costa OTFD, et al. Changes in hematological and biochemical parameters of tambaqui (Colossoma macropomum) parasitized by metazoan species. Rev Bras Parasitol Vet. 2018;27(4):488-494. doi:10.1590/S1984-296120180073

329. Godoi MMIDM, Engracia V, Lizama MDLAP, Takemoto RM. Parasite-host relationship between the tambaqui (Colossoma macropomum Cuvier 1818) and ectoparasites, collected from fish farms in the city of Rolim de Moura, State of Rondônia, Western Amazon, Brazil. Acta Amazon. 2012;42(4):515-524. doi:10.1590/ S0044-59672012000400009

330. Costa JC, Val AL. Extreme climate scenario and parasitism affect the Amazonian fish Colossoma macropomum. Sci Total Environ. 2020;726:138628. doi:10.1016/j.scitotenv.2020.138628

331. Andrade JIA, Jerônimo GT, Brasil EM, et al. Efficacy of seed extract of Bixa orellana against monogenean gill parasites and physiological aspects of Colossoma macropomum after bath treatment. Aquaculture. 2016;462(1):40-46. doi:10.1016/j.aquac ulture.2016.04.024

332. Alves CMA, Nogueira JN, Barriga IB, Santos JR, Santos GG, Tavares-Dias M. Albendazole, levamisole and ivermectin are effective against monogeneans of Colossoma macropomum (Pisces: Serrasalmidae). J Fish Dis. 2019:42(3):405-412. doi:10.1111/ jfd.12952

333. Barriga IB, Gonzales APPF, Brasiliense ARP, Castro KNC, TavaresDias M. Essential oil of Lippia grata (Verbenaceae) is effective in the control of monogenean infections in Colossoma macropomum gills, a large Serrasalmidae fish from Amazon. Aquac Res. 2020;51(9):3804-3812. doi:10.1111/are.14728
334. Delgado PM, Delgado JPM, Arenas JV, Orbe RI. Massive infestation by Perulernaea gamitanae (Crustacea: Cyclopoida: Lernaidae) in juvenile gamitana, cultured in the Peruvian Amazon. Vet Méx. 2011;42(1):59-64.

335. Tavares-Dias M, Neves LR, Santos EF, Dias MKR, Marinho RGB, Ono EA. Perulernaea gamitanae (Copepoda: Lernaeidae) parasitizing tambaqui (Colossoma macropomum) (Characidae) and the hybrids tambacu and tambatinga, cultured in northern Brazil. Ara Bras Med Vet Zootec. 2011;63(4):988-995. doi:10.1590/S0102 -09352011000400026

336. Arbildo-Ortiz H, Alvez-Robledo J, Sousa AKS. Perulernaea gamitanae (Crustacea: Lerneaidae) en juveniles de Colossoma macropomum (Characiformes: Sarrasalmidae) em cultivo semi-intensivo en Loreto, Perú. Rev Investig Vet Perú. 2019;30(1):350-356. doi:10.15381/rivep.v30i1.14726

337. Valladão GMR, Gallani SU, Pilarski F. South American fish for continental aquaculture. Rev Aquac. 2018;10:351-369.

338. Mabilia RG, de Souza SMG. Efeito do tratamento com diflubenzuron na hematologia de jundiás, Rhamdia quelen (Pimelodidae) infestados por Lernaea cyprinacea (Copepoda) em banhos de imersão de 24 horas. Acta Sci Biol Sci. 2006;28(2):159-163.

339. Maduenho LP, Martinez CB. Acute effects of diflubenzuron on the freshwater fish Prochilodus lineatus. Comp Biochem Physiol C Toxicol Pharmacol. 2008;148(3):265-272.

340. Lom J, Dyková I. Myxozoan genera: definition and notes on taxonomy, life-cycle terminology and pathogenic species. Folia Parasitol. 2013;53(1):1-36. doi:10.14411/fp.2006.001

341. Capodifoglio KR, Adriano EA, Silva MR, Maia AA. The resolution of the taxonomic dilemma of Myxobolus colossomatis and description of two novel myxosporeans species of Colossoma macropomum from Amazon basin. Acta Trop. 2019;191:17-23. doi:10.1016/j. actatropica.2018.12.026

342. Maciel PO, Affonso EG, Boijink CDL, Tavares-Dias M, Inoue LAKA, Myxobolus sp. (Myxozoa) in the circulating blood of Colossoma macropomum (Osteichthyes, Characidae). Rev Bras Parasitol Vet. 2011;20(1):82-84. doi:10.1590/S1984-29612011000100018

343. Videira M, Velasco M, Malcher CS, Santos P, Matos P, Matos E. An outbreak of myxozoan parasites in farmed freshwater fish Colossoma macropomum (Cuvier, 1818) (Characidae, Serrasalminae) in the Amazon region. Brazil. Aquac Rep. 2016;3:3134. doi:10.1016/j.aqrep.2015.11.004

344. Kumru S, Tekedar HC, Gulsoy N, Waldbieser GC, Lawrence ML, Karsi A. Comparative analysis of the Flavobacterium columnare genomovar I and II genomes. Front Microbiol. 2017;8:1375. doi:10.3389/fmicb.2017.01375

345. Pilarski F, Rossini AJ, Ceccarelli PS. Isolation and characterization of Flavobacterium columnare, (Bernardet et al. 2002) from four tropical fish species in Brazil. Braz J Biol. 2008;68(2):409-414. doi:10.1590/S1519-69842008000200025

346. Sebastião FA, Pilarski F, Lemos MVF. Isolation and molecular characterization of Flavobacterium columnare strains from fish in Brazil. Afr J Microbiol Res. 2010;2(3):22-29. doi:10.5897/JBR.9000031

347. Mielke TD. Práticas de transporte do tambaqui Colossoma macropomum: influência sobre parâmetros zootécnicos (Transport practices of tambaqui Colossoma macropomum: influence on zootechnical parameters), Master of Science Dissertation. Universidade Nilton Lins, Manaus; 2020.

348. Nielsen ME, Høi L, Schmidt AS, et al. Is Aeromonas hydrophila the dominant motile Aeromonas species that causes disease outbreaks in aquaculture production in the Zhejiang Province of China? Dis Aquat Org. 2001;46(1):23-29. doi:10.3354/dao046023

349. Rasmussen-Ivey CR, Hossain MJ, Odom SE, et al. Classification of a hypervirulent Aeromonas hydrophila pathotype responsible for epidemic outbreaks in warm-water fishes. Front Microbiol. 2016;7:1615. doi:10.3389/fmicb.2016.01615 
350. Stratev D, Odeyemi OA. An overview of motile Aeromonas septicaemia management. Aquacult Int. 2017;25(3):1095-1105. doi:10.1007/s10499-016-0100-3

351. Gallani SU, Valladão GMR, Assane IM, et al. Motile Aeromonas septicemia in tambaqui Colossoma macropomum: Pathogenicity, lethality and new insights for control and disinfection in aquaculture. Microb Pathog. 2020;149:104512. doi:10.1016/j.micpa th.2020.104512

352. Fernando-Ramos E, Nieves-Sandoval C, Siever-Morales C, Guadalupe-Contreras S, Alberto-Manchedo S. Lesiones histopatológicas y aislamiento bacteriológico em gamitanas (Colossoma macropomum) aparentemente sanas. Rev De Investig Vet Del Peru. 2016;27(1):188-195.

353. Bishop SC, Woolliams JA. On the genetic interpretation of disease data. PLoS One. 2010;5(1):e8940. doi:10.1371/journ al.pone. 0008940

354. Ortíz H, Bello R. Composición y estabilidade de los ácidos grasos de la pulpa de cachama y de sardina durante el almacenamiento em congelación. Arch Latinoam Nutr. 1992;42:460-466.

355. Aguiar JPL. Tabela de composição de alimentos da Amazônia. Acta Amazon. 1996;26(1-2):121-126.

356. Izquierdo PC, Torres GF, de Barbosa YM, Márquez ES, Allara MC. Análisis proximal, perfil de ácidos grasos, aminoácidos esenciales y contenido de minerales en doce especies de pescado de importancia comercial en Venezuela. ALAN. 2000;50:187-194.

357. Almeida NM, Batista GM, Kodaira M, Lessi E. Alterações postmortem em tambaqui (Colossoma macropomum) conservados em gelo. Ciênc Rural. 2006;36(4):1288-1293.

358. Izquierdo P, García A, Allara M, Rojas E, Torres G, González P. Análisis proximal, microbiológico y evaluación sensorial de salchichas elaboradas a base de Cachama Negra (Colossoma macropomum). Rev Cient. 2007;17(3):294-300.

359. Sleder F, Cardoso DA, Savay-da-Silva LK, Abreu JSD, Oliveira ACSD, Almeida Filho ESD. Almeida Filho ESD Development and characterization of a tambaqui sausage. Ciênc Agrotec. 2015;39:604-612. doi:10.1590/S1413-70542015000600007

360. Cartonilho MM, Jesus RS. Qualidade de cortes congelados de tambaqui cultivado. Pesq Agropec Bras. 2011;46:344-350.

361. Stansby ME. Proximate composition of fish. In: Heen E, Kreueer R, Ed. Fish in Nutrition, London, UK: Fishing News; 1962.55-60.

362. Leitão BRGS. Elaboração e avaliação nutricional da farinha da pele do tambaqui (Colossoma macropomum) e utilização em produtos alimentícios. Nexux Revista De Extensão do IFAM. 2015;1:65-70.

363. Kato, HCA, Silva, ME, Quaresma, FRP \& Freitas, AA, . Acceptance of dishes based on mechanically separated meat of tambaqui (Colossoma macropomum) in a public school, Brazil. Food Sci Nutri Technol. 2017;2(1):000115.
364. Ramos FCP, Lourenço LFH, Joele MRSP, de Souza CL, Ribeiro SCA. Tambaqui (Colossoma macropomum) sous vide: characterization and quality parameters. Semina Ciênc Agrár. 2016;37:117-130. doi:10.5433/1679-0359.2016v37n1p117

365. Rasco B, Down K, Ovissipour M. Humane harvesting initiative: The influence of harvest and post-harvest handling practices on fish welfare and product quality. J Aquac Res Development. 2015;6(2):1. doi:10.4172/2155-9546.1000303

366. Mendes JM, DairikI JK, Inoue LAKA, de Jesus RS. Advantages of recovery from pre-slaughter stress in tambaqui Colossoma macropomum (Cuvier 1816) agroindustry in the Amazon. Food Sci Technol. 2017;37(3):383-388. doi:10.1590/1678-457X.14316

367. Silva GCO, Silva SS, Carvalho JWP, Guedes SF, Loss RA. Obtenção e caracterização físico-química e microbiológica da gelatina de resíduos de matrinxã (Brycon amazonicus) e tambaqui (Colossoma macropomum). Acta Fish Aquatic Resources. 2018;6(1):74-84.

368. Cortegano CAA, de Alcântara AM, da Silva AF, et al. Finishing plant diet supplemented with microalgae meal increases the docosahexaenoic acid content in Colossoma macropomum flesh. Aquac Res. 2019;50(4):1291-1299. doi:10.1111/are.14005

369. Vieira BB, Carvalho EA, Bispo ASR, Ferreira MA, EvangelistaBarreto NS. Efficiency of chitosan synergism with clove essential oil in the coating of intentionally contaminated tambaqui fillets, Semina: Ciênc Agrár. 2020;41:2793-2802. doi:10.5433/1679$0359.2020 v 41 n 6 p 2793$

370. Fogaça FDS, Savay-Da-Silva LK, Prentice-Hernández C, et al. Tecnologias para o Processamento do Tambaqui (Colossoma macropomum):2018. EMBRAPA Agroindústria de Alimentos-Documento. 131th ed. Rio de Janeiro: Embrapa Agroindústria de Alimentos; 2018.

\section{SUPPORTING INFORMATION}

Additional supporting information may be found in the online version of the article at the publisher's website.

How to cite this article: Hilsdorf AWS, Hallerman E, Valladão GMR, et al. The farming and husbandry of Colossoma macropomum: From Amazonian waters to sustainable production. Rev Aquac. 2021;00:1-35. doi:10.1111/raq.12638 